\title{
Deep water Actiniaria (Cnidaria: Anthozoa) Sicyonis, Ophiodiscus and Tealidium: re-evaluation of Actinostolidae and related families
}

\section{N.P. Sanamyan ${ }^{1}$, K.E. Sanamyan ${ }^{1 *}$, S.V. Galkin ${ }^{2}$, V.V. Ivin ${ }^{3,4}$, E.S. Bocharova ${ }^{5}$}

\author{
${ }^{1}$ Kamchatka Branch of Pacific Geographical Institute, Far Eastern Branch of the Russian Academy \\ of Sciences, Partizanskaya 6, Petropavlovsk-Kamchatsky, 683000, Russia. E-mail: \\ actiniaria@sanamyan.com \\ ${ }^{2}$ Shirshov Institute of Oceanology of Russian Academy of Sciences, Nahimovskiy Pr. 36, Moscow, \\ 117997,Russia.E-mail: galkin@ocean.ru \\ ${ }^{3}$ A.V. Zhirmunsky National Scientific Center of Marine Biology, Far Eastern Branch of Russian \\ Academy of Sciences, Palchevskogo 17,Vladivostok, 690041 Russia.E-mail:victor.ivin@mail.ru \\ ${ }^{4}$ L.S. Berg State Research Institute on Lake and River Fisheries, Naberezhnaya Makarova 26, St. \\ Petersburg, 199004, Russia. \\ ${ }^{5}$ Koltzov Institute of Developmental Biology of Russian Academy of Sciences, Vavilova Str. 26, \\ Moscow, 119334, Russia. E-mail: bocharova.ekaterina@gmail.com \\ * Corresponding author \\ N.P. Sanamyan ORCID 0000-0002-9987-0668 \\ K.E. Sanamyan ORCID 0000-0002-7460-3985 \\ S.V. Galkin ORCID 0000-0002-9748-5168 \\ V.V. Ivin ORCID 0000-0001-7161-8527 \\ E.S. Bocharova ORCID 0000-0001-9978-3006
}

ABSTRACT: Several species of deep-water sea anemones belonging to three genera, Sicyonis, Ophiodiscus and Tealidium, previously assigned to Actinostolidae, are recorded in North Pacific and North Atlantic and described. It is shown that these genera cannot be maintained within Actinostolidae. Family Sicyonidae was reinstated for Sicyonis and Ophiodiscus, while Tealidium, together with related Anthosactis and Hormosoma, is transferred to a new family Anthosactinidae fam.n. Recently described Tetracoelactis, originally assigned to Exocoelactinidae, is transferred to a new family Tetracoelactinidae fam.n., which shows some affinity with Sicyonidae. Removing Sicyonis from Actinostolidae in the present work resulted in the validation of this family: till now wide usage of this family name was invalid because Actinostolidae Carlgren, 1893 was a junior subjective synonym of Sicyonidae Hertwig, 1882. The following new taxa are described: Sicyonis denisovi sp.n., Sicyonis kuznetsovi sp.n., Sicyonis titanic sp.n., Ophiodiscus bukini sp.n., Ophiodiscus moskalevi sp.n., Tealidium konoplinorum sp.n., Anthosactinidae fam.n., Tetracoelactinidae fam.n.

How to cite this article: Sanamyan N.P., Sanamyan K.E., Galkin S.V., Ivin V.V., Bocharova E.S. 2021. Deep water Actiniaria (Cnidaria: Anthozoa) Sicyonis, Ophiodiscus, and Tealidium: re-evaluation of Actinostolidae and related families // Invert. Zool. Vol.18. No.4. P.385-449 , Suppl.Fig.1, Suppl.Fig.2, Suppl.Tab. doi: 10.15298/invertzool.18.4.01

KEY WORDS: Sea anemone, Actiniaria, Actinostolidae, deep-sea fauna, Sicyonidae, Anthosactinidae, Tetracoelactinidae, new family. 


\title{
Глубоководные актинии (Cnidaria: Anthozoa: Actiniaria) родов Sicyonis, Ophiodiscus и Tealidium: ревизия Actinostolidae и родственных семейств
}

\author{
Н.П. Санамян', К.Э. Санамян ${ }^{1 *}$, С.В. Галкин ${ }^{2}$, В.В. Ивинн, \\ Е.С. Бочарова ${ }^{5}$
}

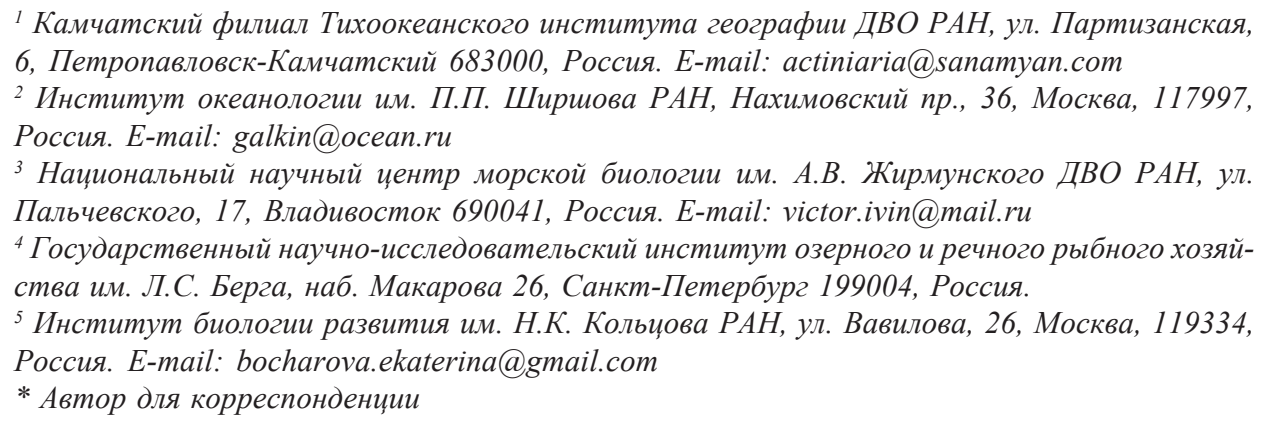

РЕЗЮМЕ: Несколько глубоководных актиний родов Sicyonis, Ophiodiscus и Tealidium, которые ранее относили к Actinostolidae, описаны из северной части Тихого и Атлантического океанов. Показано, что эти роды не следует относить к семейству Actinostolidae. Для родов Sicyonis и Ophiodiscus восстановлено семейство Sicyonidae. Род Tealidium, вместе с родственными Anthosactis и Hormosoma, перенесен в новое семейство Anthosactinidae fam.n. Недавно описанный род Tetracoelactis, оригинально отнесенный к Eхосоelactinidae, перемещен в новое семейство Tetracoelactinidae fam.n., которое имеет некоторое сходство с Sicyonidae. Удаление рода Sicyonis из Actinostolidae привело к валидации этого семейства: до настоящего времени широкое использование этого названия было невалидным, так как Actinostolidae Carlgren, 1893 являлось младшим субъективным синонимом Sicyonidae Hertwig, 1882. В работе описаны следующие таксоны: Sicyonis denisovi sp.n., Sicyonis kuznetsovi sp.n., Sicyonis titanic sp.n., Ophiodiscus bukini sp.n., Ophiodiscus moskalevi sp.n., Tealidium konoplinorum sp.n., Anthosactinidae fam.n., Tetracoelactinidae fam.n.

Sanamyan N.P., Sanamyan K.E., Galkin S.V., Ivin V.V., Bocharova E.S. 2021. Deep water Actiniaria (Cnidaria: Anthozoa) Sicyonis, Ophiodiscus, and Tealidium: re-evaluation of Actinostolidae and related families // Invert. Zool. Vol.18. No.4. P.385-449, Suppl.Fig.1, Suppl.Fig.2, Suppl.Tab. doi: 10.15298/invertzool.18.4.01

КЛЮЧЕВЫЕ СЛОВА: Морские анемоны, Actiniaria, Actinostolidae, глубоководная фауна, Sicyonidae, Anthosactinidae, Tetracoelactinidae, новые семейства. 


\section{Introduction}

Three genera of sea anemones, Sicyonis Hertwig, 1882, Ophiodiscus Hertwig, 1882 and Tealidium Hertwig, 1882, discussed in the present work, were previously assigned to a large family Actinostolidae. These genera comprise relatively large (or sometimes very large) species of deep-water sea anemones. They probably constitute a significant component of deepwater fauna and may occur in large numbers in some habitats (e.g. in abyssal plains of North Atlantic, see Doumenc, 1975 and RiemannZürneck, 1991) but are surprisingly poorly known and rarely recorded. In particular, the genus Sicyonis currently contains 16 species, 12 of which are known only from the original descriptions often based on a single or a few specimens. Members of Ophiodiscus are reported here for the first time since this genus was described by Hertwig (1882) from a material collected by Challenger Expedition, and two previously known species of Tealidium also are known from very old original descriptions (Hertwig, 1882 and Carlgren, 1921). Type material of all previously known species of Ophiodiscus and Tealidium is in poor condition: the material collected by Challenger Expedition and described by Hertwig (1882) was fixed in chromic acid and the specimens were already in a very mutilated condition when he examined them; Riemann-Zürneck (1997) tried to reexamine type specimen of Tealidium jungerseni Carlgren, 1921 but gathered no valuable information from it. In contrast, the newly recorded specimens of Sicyonis, Ophiodiscus, and Tealidium, reported in the present work, especially the specimens from North Pacific collected by ROV during two recent expeditions, are in excellent condition and, that is especially important, accompanied by underwater photographs of live expanded specimens in their natural habitat. This material allowed us not only to provide very detailed descriptions of new species belonging to Sicyonis, Ophiodiscus, and Tealidium, but also to reveal a familiar assignment of discussed genera and show, on the basis of their morphology supported by molecular data, that they should not be maintained in the family Actinostolidae.

\section{Material and methods}

The main part of the material, used in the present study, was collected in 2016 and 2018 during 75 and 82 cruises of RV Akademik M.A. Lavrentyev in the Bering Sea. In these expeditions the specimens were collected by ROV Comanche 18 NSCMB FEB RAS (A.V. Zhirmunsky National Scientific Center for Marine Biology, Far East Branch of Russian Academy of Sciences). Most of them were photographically documented by ROV Comanche 18 in natural habitat and photographs were kindly provided by NSCMB FEB RAS. In addition, available specimens collected by the following expeditions were used: 22 cruise of RV Akademik Mstislav Keldysh, 1990, NE Pacific; 49 cruise of RV Akademik Mstislav Keldysh, 2003, East Atlantic; RV G.O. Sars, MAR-ECO cruise, 2004, North Atlantic.

The main methods and terminology are the same as in our previous papers (the preparation of histological sections is outlined in details by Sanamyan $e t$ al., 2019; the usage of basic dyes to stain nematocysts in Sanamyan et al., 2013; cnidae terminology and the usage of other terms in Sanamyan et al., 2012). We should especially stress that we consider important to use the method of Hand (1954) to study cnidae. This method allows precisely determine the size ranges of cnidae (by scanning the whole sample for largest and smallest capsules) which we consider a more valuable characteristic for the species than mean values or size ranges obtained by measurement limited number of randomly selected cnidae. The latter method produces statistically significant differences not only between the samples from different specimens of the same species, but also between mean lengths of cnidae in replicate samples from the same specimen (see Williams, 1996). It makes no sense to indicate the number of measured cnidae when the method of Hand (1954) is used (because in most cases hundreds or thousands capsules are evaluated), but for rare types of cnidae we indicate in the text the number of measured ones. All nematocyst listed in Tables 1-7 were found in all mentioned specimens, unless otherwise indicated in the text.

In the specimens which have bilateral symmetry in relation to the directive plane we conditionally distinguish "dorsal" and "ventral" directives and, accordingly, "dorsal", lateral and "ventral" primary exocoels (in analogy or homology with Tetracoelactis ioran Sanamyan, Sanamyan, 2019 and in agreement with Carlgren, 1921: 216, who used the term "ventrolateral primary exocoels" for the exocoels named here "ventral").

The specimens are stored in Museum of the Institute of Marine Biology, A.V. Zhirmunsky Na- 
tional Scientific Center of Marine Biology FEB RAS, Vladivostok (MIMB) and Zoological Museum Moscow State University (ZMMU).

For molecular analysis small pieces of tissues fixed in $96 \%$ ethanol were used. Total DNA was extracted using Wizard SV Genomic DNA Purification System (Promega) following the manufacturer's protocol. The mitochondrial (12S rRNA, 16S rRNA, COIII) and nuclear (18S rRNA and $28 \mathrm{~S}$ rRNA) gene fragments were amplified using published primers and protocols (Geller, Walton, 2001; Bocharova, 2015; Sanamyan et al., 2018).

Sequence reaction was run using the BigDye v3.1 reagent kit (Applied Biosystems ${ }^{\mathcal{C}}$ ). Purified and denatured reaction products were analyzed in the capillary molecular analyzer ABI PRISM 3500 (Applied Biosystems ${ }^{\circ}$ ) using POP7 gel polymer. In order to treat the chromatograms, a Sequencing Analysis 3.7 (Applied Biosystems ${ }^{\circ}$ ) and Geneious R10 were applied. Forward and reverse sequences were assembled in and compared (via BLAST) against the nucleotide database of GenBank to determine whether the target locus and organism were sequenced rather than a symbiont or other contaminant. Additional molecular data were obtained from GenBank. Species names and GenBank accession numbers of the DNA sequences used for the phylogenetic analysis are listed in Supplement Table 1.

Sequences were aligned separately for each marker using the Mafft v7.409 with E-INS-i algorithm and "-maxiterate 1000" option (Katoh, Standley, 2013). Alignments were inspected and edited manually in AliView v.1.24 (Larsson, 2014). Final concatenated alignment contained $4481 \mathrm{bp}$ including gaps. A ML tree was generated by IQ-TREE v.1.6.12 (Nguyen et al., 2015) running on local machine using automatic model selection (Kalyaanamoorthy et al., 2017) and ultrafast bootstrap approximation (Hoang et al., 2018). Bayesian estimation of posterior probability was performed in MrBayes 3.2.6 (Ronquist et al., 2012). Four Markov chains were sampled at intervals of 500 generations. Analysis was started with random starting trees and $10^{7}$ generations. To view, edit and print final tree MEGA7 (Kumar et al., 2016) was used.

\section{Taxonomic history of discussed taxa}

Three genera, Sicyonis, Ophiodiscus and Tealidium, members of which are described in the present paper, were originally described by Hertwig (1882) in his fundamental work based on the material collected by Challenger Expedition. In this work Hertwig
(1882) created several families: the genus Sicyonis was placed into its own family Sicyonidae Hertwig, 1882, while the genera Ophiodiscus and Tealidium and a number of other genera were placed to the family Paractinidae Hertwig, 1882. Sicyonidae, according to Hertwig (1882: 41), characterized by "tetramerous arrangement of septa" and small knoblike tentacles while Paractinidae comprised "Hexactiniae with numerous perfect septa" and with strong mesogloeal sphincter.

Carlgren (1893: 66) formally placed the genus Actinostola Verrill, 1883 in Paractinidae, but then, in the same work (Carlgren, 1893: 137), created a new family Actinostolidae Carlgren, 1893 for Actinostola and Stomphia Gosse, 1859 in which mesenteries in younger cycles are unequally developed and suggested to save Paractinidae for species in which individual mesenteries in each pair are equally developed. Stephenson (1920) accepted Actinostolidae as a subfamily of Paractinidae. He recognized three subfamilies of Paractinidae:

1) Paractinae, comprising genera with the mesenteries of one and the same pair "about equally developed, or if any inequality occurs it is irregularly developed" (Stephenson, 1920: 549);

2) Actinostolinae, in which youngest cycles of the mesenteries are unequally developed according to so called Actinostola-rule ("one partner in each pair being larger than the other in such a way that that partner is always larger which stands further away from the adjacent mesenterial pair of the next oldest cycle" Stephenson, 1920: 549);

3) Polysiphoniinae, currently recognized as Exocoelactinidae Carlgren, 1925.

Stephenson (1920) placed Tealidium and Sicyonis to subfamily Paractinae while Ophiodiscus was assigned to Actinostolinae. Carlgren (1921) questioned distinction between Paractinae and Actinostolinae and used Paractinidae as a valid family name. Later Carlgren (1932) decided that the genus Paractis Milne-Edwards et Haime, 1851 is too poorly known and began to use the name Actinostolidae instead of Paractinidae for almost the same set of genera. In his catalogue of genera and families Carlgren (1949) provided diagnoses of Actinostolidae and 20 genera he included in this family. According to Carlgren (1949) the family Actinostolidae comprises all sea anemones with definite base, mesogloeal sphincter, no acontia and not bilaterally arranged mesenteries which are not divisible into macro- and microcnemes. Basing on the above mentioned criteria several genera were added to this family in the second half of the 20-th century.

Riemann-Zürneck (1978) was first who recognized that the family is heterogeneous and comprises 
not related genera. Basing solely on the nematocyst data she reinstated the family Actinoscyphiidae Stephenson, 1920 and removed Actinoscyphia Stephenson, 1920 and very similar Epiparactis Carlgren, 1921 from Actinostolidae. Further molecular studies supported her opinion (Rodríguez, Daly, 2010). Subsequently many other genera were removed from Actinostolidae on the basis of morphological and molecular data (summarized by Rodríguez et al., 2012).

Until recently the family Actinostolidae contained 17 genera (Fautin, 2016) and one more genus, Chitinactis Gusmão et Rodríguez, 2021, was recently added (some its features strongly resemble Condylanthus Carlgren, 1899). Many of them are poorly known and some appear to be not closely related to its type genus Actinostola. In the present paper we remove Sicyonis and Ophiodiscus from Actinostolidae and reinstate the family Sicyonidae Hertwig, 1882 for them, and create a new family Anthosactinidae fam.n. for Anthosactis Danielssen, 1890, Hormosoma Stephenson, 1918 and Tealidium.

Rodríguez et al. (2014) ranked a clade containing members of Actinostola, Stomphia, Hormosoma and Anthosactis as a superfamily Actinostoloidea. They defined Actinostoloidea as a superfamily containing Actinostolidae and Exocoelactinidae. The genus Capnea Forbes, 1841 (family Capneidae), which in their phylogeny recovered as sister to Actinostola+Stomphia clade was not included to Actinostoloidea. Gusmão et al. (2019) suggested changes in the diagnosis of the superfamily to include Halcampulactis Gusmão et al., 2019, which is recovered among these genera. Gusmão \& Rodríguez (2021: 11) included also Halcampoididae to Actinostoloidea "given its position in our phylogenetic analysis" (a statement not supported by phylogenetic tree they gave, see Gusmão, Rodríguez, 2021, Fig. 2). Capnea, in their ML analysis again nestled between former actinostolid genera, it was marked as a member of Actinostoloidea (Gusmão, Rodríguez, 2021, Fig. 2) but not included in the list of families included in Actinostoloidea. In our analysis Halcampoides Danielssen, 1890 shows no any affinity with former actinostolid genera (Supplement Figs 1, 2), nor it has any morphological traits that may suggest such affinity. It is obvious that the position of some taxa on the phylogenetic trees strongly depends on the details of used methods and a set of taxa included in analysis. The composition and limits of suprafamiliar taxa could not and should not be determined on the basis of molecular evidences only. Pending further studies, which hopefully may shed light on a very confused situation around suprafamiliar taxa in Actiniaria, we prefer to refrain from uniting discussed families to one superfamily. (Note, that Sicyonioidea Hertwig, 1882 has a priority over Actinostoloidea Carlgren, 1893).

\section{Nomenclatural notes and current status of discussed families}

1) Paractinidae Hertwig, 1882. Invalid, a junior synonym of Sagartiidae Gosse, 1858. Type genus is Paractis Milne-Edwards et Haime, 1851. Fautin (2016) ascribed this family to Andres (1884) who indeed used this family-rank name but Hertwig (1882) created it earlier. Type species of Paractis is Actinia impatiens Couthoy in Dana, 1846, a species redescribed by McMurrich (1904), who showed that it belongs to Sagartiidae. Therefore, family name Paractinidae Hertwig, 1882 is a junior synonym of Sagartiidae Gosse, 1858. (Sagartiidae was recently validated by Sanamyan, Sanamyan, 2020.)

3) Polysiphoniidae Carlgren, 1918. Invalid, type genus is a junior homonym (Article 39). Type genus Polysiphonia Hertwig, 1882 is a junior homonym of Polysiphonia Pomel, 1872 (Sponges). Exocoelactis Carlgren, 1925 was suggested as a replacement name for Polysiphonia Hertwig, 1882 and current valid family name is Exocoelactinidae Carlgren, 1925.

2) Sicyonidae Hertwig, 1882. Valid, reinstated in the present work. Type genus is Sicyonis Hertwig, 1882. Sicyonidae Hertwig, 1882 is older than Sicyoniidae Ortmann, 1898 (Crustacea, type genus Sicyonia Milne-Edwards, 1830). The crustacean taxon was originally spelled as Sicyoninae, but this name was placed on the Official Index of Rejected and Invalid Family-Group names in Zoology (see ICZN, 1956, Direction 54) while Sicyoniinae Ortmann, 1898 (correction of Sicyoninae Ortmann, 1898) placed on the Official List of Family-Group Names in Zoology and currently considered valid. As a result, Sicyonidae Hertwig, 1882 and Sicyoniidae Ortmann, 1898 are not homonyms because they differ in one letter (Article 55.4).

3) Actinostolidae Carlgren, 1893. Validated in the present work (by removing Sicyonis from this family). Type genus is Actinostola Verrill, 1883. Carlgren (1949) incorrectly ascribed this family to his work published in 1932 (as "Actinostolidae Carlgren, 1932") and this incorrect date was repeated by almost all other subsequent authors (e.g. Manuel, 1981; Fautin, 2016, etc.). Carlgren (1949) explicitly included the genus Sicyonis to this family, and since the family Sicyonidae Hertwig, 1882 has a priority over Actinostolidae Carlgren, 1893, his usage of Actinostolidae rather than Sicyonidae was not correct. Despite the fact that the name Actinostolidae 
currently is firmly established in the literature and was used in all works dealing with the corresponding genera, the precedence of Sicyonidae could not be suppressed by using Article 23.9.1 because it was used as valid after 1899 (e.g. by Bourne, 1900). Fortunately, as is shown below in the present work, Sicyonis is not confamiliar with Actinostola and therefore family name Actinostolidae is not threatened by Sicyonidae.

\section{Taxonomy}

\section{Order Actiniaria \\ Family Sicyonidae Hertwig, 1882}

DIAGNOSIS. Actiniaria with definite base and mesogloeal sphincter which is not separated from circular endodermal musculature of column and forms endo-mesogloeal complex with it. Acontia not present. Mesenteries differentiated into stronger sterile mesenteries which have filaments and weaker fertile mesenteries of the last cycle without filaments. Cnidom: spirocysts, basitrichs, $p$-mastigophores A and $p$-mastigophores B1.

Included genera: Sicyonis Hertwig, 1882 (type genus) and Ophiodiscus Hertwig, 1882.

The family Sicyonidae (originally spelled as Sicyonidæ) was created by Hertwig (1882) for only one the genus, Sicyonis. According to Hertwig (1882) the most important features of his family are the tetramerous (as he believed) arrangement of the tentacles and mesenteries and a reduction of the tentacles to knob-like structures. None of these features may be used as a family character. The morphological characters separating Sicyonidae from Actinostolidae (a family to which Sicyonis was assigned by Carlgren, 1921, 1949 and all subsequent authors) are the following:

1) In Sicyonis and Ophiodiscus the mesenteries are differentiated into filament bearing sterile and filament lacking fertile mesenteries - a feature not reported for any other former member of Actinostolidae sensu Carlgren (1949).

2) Although Carlgren (1949: 77) placed Sicyonis into the section entitled "Mesenteries indistinctly arranged according to Actinostola-rule" and Ophiodiscus into the section "Mesenteries distinctly arranged according to Actinostola-rule" we failed to confirm the presence of Actinostola-rule in any species of Sicyonis and Ophiodiscus we had chance to examine. Actinostola-rule describes a peculiar arrangement of the mesenteries of several youngest cycles in Actinostola composed of larger and smaller imperfect mesenteries. In contrast, in Sicyonis the last (=the youngest) cycle represented by fertile mesenterial pairs composed by mesenteries of equal size. Penultimate cycle is represented by imperfect sterile mesenterial pairs also composed of mesenteries of about the same size. Some pairs of older cycles of sterile mesenteries (except the first cycle) may be composed of one perfect and one imperfect mesentery. Thus, the inequality in the mesenteries in Sicyonis differs significantly from that in Actinostola.

3) Members of Sicyonidae have $p$-mastigophores $\mathrm{B}$ (along with $p$-mastigophores A) while all species of Actinostola and Stomphia (members of Actinostolidae sensu stricto), for which this feature was reported, have only $p$-mastigophores $\mathrm{A}$. We found $p$ mastigophores B in the filaments of all Sicyonis and Ophiodiscus species described in the present work.

4) Molecular data strongly support the monophyly of clades Sicyonis + Ophiodiscus, Anthosactis + Tealidium + Hormosoma and Actinostola + Stomphia (=Sicyonidae, Anthosactinidae fam.n. and Actinostolidae sensu stricto). Two different phylogenetic methods, Bayesian inference (BI) and Maximum Likelihood (ML), used to infer evolutionary relationships, resulted in very similar phylogenetic trees (Supplement Fig. 1 and Fig. 2) with high support of above mentioned clades: $100 \%$ bootstrap support on ML and posterior probability $=1$ in BI (Fig. 38). In the same time, support values are lower on the branches joining these clades, and they are separated by genera belonging to other families (Exocoelactinidae, Capneidae and Halcampulactinidae). Together with distinct morphological differences this demonstrates the need for these clades to be treated as separate families. Alternative approach, uniting together all these genera in one family (including, possibly, members of Exocoelactinidae, Capneidae and Halcampulactinidae) would considerably obscure both morphological and molecular diversity and is not acceptable.

Currently we include in Sicyonidae only two genera, Sicyonis and Ophiodiscus. Carlgren (1921) created a new genus Synsicyonis Carlgren (1921) for a species described by Hertwig (1888) as Sicyonis elongata Hertwig, 1888. Original description of this species is based on one poorly preserved specimen which was "so strongly contracted that one could hardly find the entrance to the oral disc" (Hertwig, 1888: 33). According to Hertwig (1888) this specimen agrees with Sicyonis in most features but fertile mesenteries are in the distal part of column while in Sicyonis they are in proximal part. Hertwig's (1888) description, however, suggests that he misinterpreted the morphology of this specimen. The presence of an additional cycle of fertile mesenteries in the distal part of the body is highly unlikely. Also, in this case 
the specimen should have twice as many tentacles as in opposite case while Hertwig (1888) counted 53 tentacles, a number typical for Sicyonis. In strongly contracted damaged preserved specimens of sea anemones the tentacles may sometimes protrude through the rupture of the pedal disc and there is a possibility that Hertwig (1888) mixed oral and aboral ends of his specimen. Anyway, due to the existence of only one poorly preserved specimen of this species, its status cannot be solved without additional material from type locality. In the present paper we prefer to consider Synsicyonis as a probable synonym of Sicyonis.

\section{Genus Sicyonis Hertwig, 1882}

Type species: Sicyonis crassa Hertwig, 1882, by monotypy.

The most noticeable feature of the genus Sicyonis is the differentiation of the mesenteries into stronger sterile mesenteries with well-developed filaments and smaller fertile mesenteries of the last cycle which have no filaments and present only in the proximal part of the body. The tentacles are arranged in two or more cycles.

Sicyonis includes 16 species, all are known exclusively from deep-water habitats. Most of them are based on a single or a few records. Half of them, eight species, are known exclusively from North Atlantic: S. gossei (Stephenson, 1918), S. variabilis Carlgren, 1921, S. tuberculata Carlgren, 1921, S. ingolfi Carlgren, 1921, S. obesa (Carlgren, 1934), S. haemisphaerica Carlgren, 1934, S. biotrans Riemann-Zürneck, 1991 and $S$. titanic sp.n. Five species are known from Pacific: $S$. tubulifera (Hertwig, 1882), S. careyi Eash-Loucks et Fautin, 2012, S. heliodiscus Sanamyan et al., 2015, S. denisovi sp.n. and S. kuznetsovi sp.n.; two from Indian Ocean: $S$. crassa Hertwig, 1882 and $S$. sumatriensis Carlgren, 1928 and one from Antarctic: S. erythrocephala (Pax, 1922).

Currently the genus Sicyonis contains species with rather different morphologies and the genus may be divided into several separate genera when more information will be accumulated. In particular, the distribution the tentacles over the oral disc varies significantly in different species: the tentacles may be distributed over a significant part of the oral disc (S. erythrocephala), or arranged in several cycles on the external half of the disc (e.g. S. denisovi sp.n.), or in two cycles on periphery of the disc ( $S$. crassa, $S$. heliodiscus, $S$. biotrans). The shape of the body also varies considerably, from "typical actiniid" shape (with high column) in some species, to disc shaped as in S. heliodiscus. It is evident that the species currently assigned to Sicyonis display a mosaic of discussed above features whose significance at present is difficult to evaluate. However, for convenience they may be divided into the following two groups:

The first group includes the species with the tentacles arranged into two distinct circles on the margin (or very close to margin) of wide oral disc. This group certainly includes the type species of the genus, $S$. crassa, and also $S$. biotrans, $S$. ingolfi, $S$. heliodiscus, S. gossei, S. titanic sp.n. and, possibly, $S$. obesa and $S$. haemisphaerica. At least some species of this group (S. biotrans, S. ingolfi, S. titanic sp.n. and possibly several other), live unattached on soft bottom, in preserved condition they have a characteristically looking aboral side with a cavity which may be filled by mud and remnants of cuticlelike material (Fig. 16C). They all have thick-walled tentacles. External appearance of live expanded specimens in their natural habitat is known for two species in this group, S. biotrans and S. heliodiscus (see Riemann-Zürneck,1991 and Sanamyan et al., 2015b). Sicyonis biotrans has high column and large flat oral disc with two diverging rows of long straight tentacles at its margin. Sicyonis heliodiscus has a very different appearance, its column in live is very short and the whole anemone is disc-shaped, the tentacles are short but, as in other species of this group, are in two distinct rows on the margin of the disc.

The second group includes the species with three or more circles of the tentacles: $S$. careyi, S. erythrocephala, S. variabilis, S. tuberculata, S. tubulifera, S. denisovi sp.n., S. kuznetsovi sp.n. The tentacles occupy a greater part of the oral disc than in the first group, and live specimens of this group have a more "usual" appearance and resemble many other large sea anemones (e.g. large members of Urticina Ehrenberg, 1834, Actinostola, etc.). In some species of this group (e.g. S. denisovi sp.n.) the tentacles are thinwalled, in other the mesogloea may be thickened, especially on the aboral side of the bases of the tentacles.

\section{Sicyonis denisovi sp.n. Table 1; Figs 1-6.}

MATERIAL EXAMINED. NW Pacific, the south-west Bering Sea, Volcanologists Massif. RV Akademik M.A. Lavrentyev, 82 cruise, ROV Comanche 18 NSCMB FEB RAS: St. 7, sample 2, $55.3688^{\circ} \mathrm{N}, 167.2662^{\circ} \mathrm{E}, 981 \mathrm{~m}, 17$ June 2018 , two specimens (holotype MIMB 41366, paratype MIMB 41367 ); St. 1 , sample $1,55.4171^{\circ} \mathrm{N}, 167.2773^{\circ} \mathrm{E}$, $386 \mathrm{~m}, 13$ June 2018 one specimen (paratype MIMB 41368). RV Akademik M.A. Lavrentyev, 75 cruise, 
Table 1. Size ranges (length $\times$ width, in microns) and distribution of cnidae of Sicyonis denisovi sp.n. (based on five specimens). Letters in brackets correspond to letters in Fig. 6. Таблица 1. Размеры (длина × ширина, в микронах) и распределение стрекательных капсул Sicyonis denisovi sp.n. (по пяти экземплярам). Буквы в скобках соответствуют буквам на рис. 6.

\begin{tabular}{lll}
\hline Body region & Cnidae & Size ranges $(\mu \mathrm{m})$ \\
\hline Pedal disc & (A) basitrichs (common) & $21-34 \times 2.2-3.5$ \\
\hline Column & (B) basitrichs (common) & $21-41 \times 2.5-3.5$ \\
\hline \multirow{2}{*}{ Tentacles } & (C) spirocysts (very numerous) & $19-74 \times 2-7.5$ \\
& (D) basitrichs (common) & $23-47 \times 2.5-3.5$ \\
\hline \multirow{2}{*}{ Actinopharynx } & (E) basitrichs (common) & $15.5-38.5 \times 2-4$ \\
& (F) p-mastigophores A (common-rare) & $22-33 \times 4-7$ \\
\hline \multirow{2}{*}{ Filaments } & (G) p-mastigophores B1 (common-very rare) & $22-32 \times 3.5-5$ \\
\hline Endoderm & (H) p-mastigophores A (common-few) & $23-32 \times 4-6.5$ \\
\hline
\end{tabular}

ROV Comanche 18 NSCMB FEB RAS: St. 1, sample $1,55.4246^{\circ} \mathrm{N}, 167.2903^{\circ} \mathrm{E}, 1061 \mathrm{~m}, 11$ June 2016, one specimen (paratype MIMB 41371); St. 9 , sample 2, $55.4282^{\circ} \mathrm{N}, 167.2772^{\circ} \mathrm{E}, 986 \mathrm{~m}, 19$ June 2016, one specimen (paratype MIMB 41372).

DESCRIPTION. More than 20 specimens were photographically documented by ROV during two expeditions, five of them were collected. All are large, the diameter of the tentacular crown of live specimens is about $20-25 \mathrm{~cm}$, the column is about 12 $\mathrm{cm}$ in diameter and of about the same height. Preserved specimens have a form of a short wide cylinder 7-10 $\mathrm{cm}$ in diameter and $2.5-6.5 \mathrm{~cm}$ in height, the holotype is $7 \times 6 \mathrm{~cm}$ (Fig. 1D, E). In live the colour of the oral disc and the tentacles is red, the ectoderm of the column is brownish-red (Fig. 1A, B). The tentacles are uniformly coloured, the oral disc has darker radial bands over each exo- and endocoel composed of series of short thin transverse stripes (Fig. 1A). In formalin the tentacles, the oral disc and the actinopharynx are dark brown, the ectoderm of the column light brown (Figs 1D, E; 2A).

The column is almost cylindrical or slightly tapering distally with the pedal disc spread into a rather thick broad membrane (Fig. 2A). The pedal disc and the limbus are paler than the column (beige in preservative). The remnants of thin easily peeling cuticle are present on the pedal disc. In expanded live specimens the surface of the column is smooth but coarsely wrinkled in contracted preserved specimens. The column is thick-walled, the thickness of the mesogloea in its distal part is $5 \mathrm{~mm}$. Toward the limbus the mesogloea becomes gradually thinner to less than $1 \mathrm{~mm}$ thick in the most proximal part of the column. Its thickness rapidly decreases to $25 \mu \mathrm{m}$ on the border between the column and the pedal disc. The mesogloea of the pedal disc is $100-300 \mu \mathrm{m}$. The ectoderm of the column is up to $100 \mu \mathrm{m}$ thick, the endoderm is $40-60 \mu \mathrm{m}$. In contracted specimens a distinct ridge $2-3 \mathrm{~mm}$ in height and width is formed on the margin (Fig. 2A, B). Large mesogloeal swellings, probably caused by contraction, are sometimes very distinct on the margin (Fig. 1C). The distal part of the column cannot cover the tentacles completely: in the preserved specimens most tentacles and a part of the oral disc are usually visible from the exterior (Fig. 1D).

The tentacles are numerous (192 in holotype and $158,192,176,213$ in paratypes) short, conical, more or less pointed in live, with blunt and perforated tips in fixed specimens (Fig. 1A, D). They are arranged in several (four or five) cycles on the periphery of the oral disc so that the whole central part of the disc is devoid of them. The tentacles are thin-walled, they possess no mesogloeal thickenings, the thickness of the mesogloea is the same along the whole their length (Fig. 4D, E).

The oral disc is flat, circular and wider than the column (Fig. 1A). Its mesogloea forms thick radial ridges along each exo- and endocoel (Fig. 4C).

The marginal sphincter muscle is weak, relatively long (about $1 \mathrm{~cm}$ in longitudinal section) and thin in comparison with the body size, wider in distal end (up to $0.6 \mathrm{~mm}$ ) and gradually tapering proximally (Fig. 2B). It is mostly mesogloeal and confined to the endodermal side of the wall of column, not separated from the endodermal circular columnar muscles and forms endo-mesogloeal complex with these mus- 

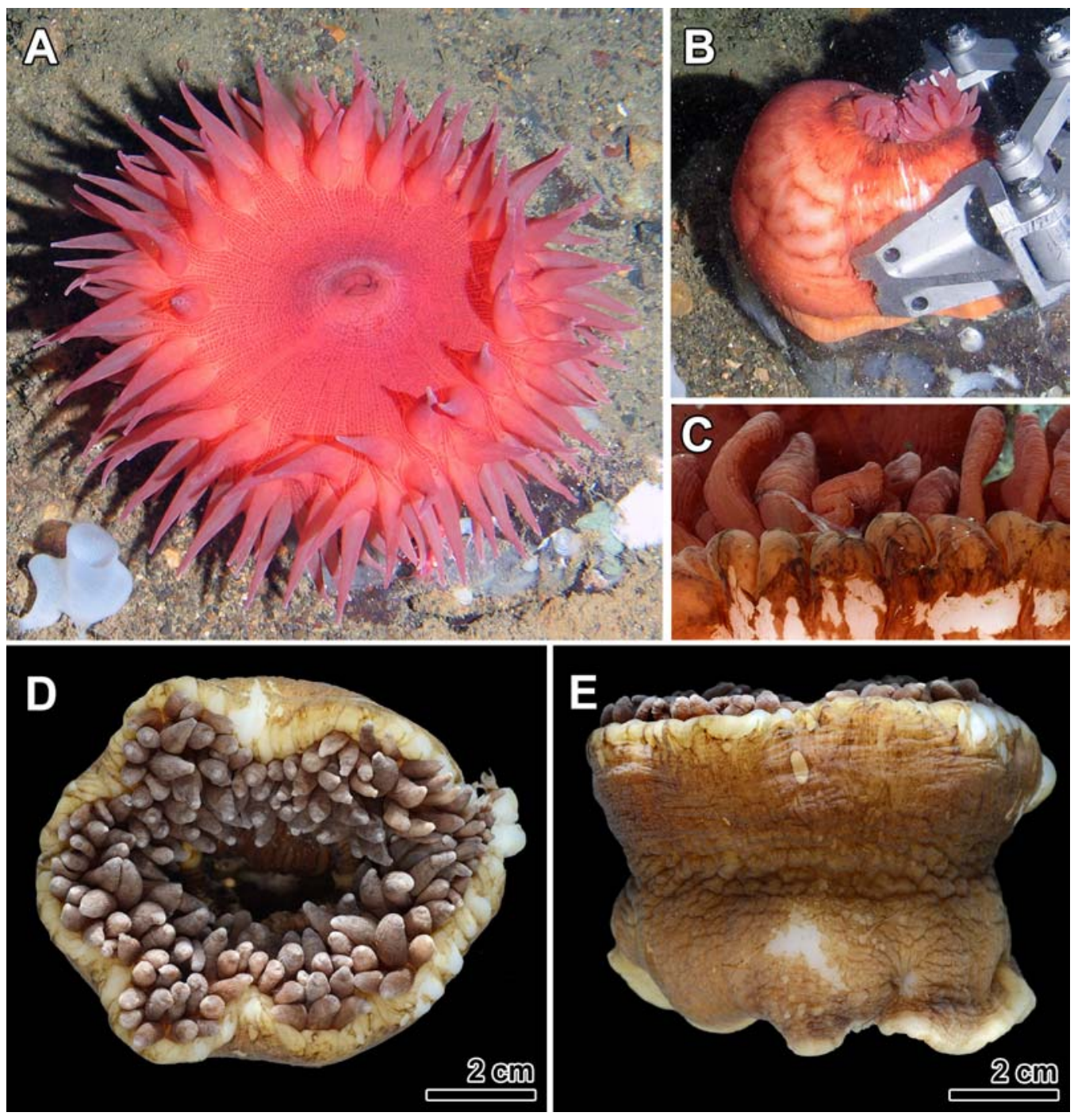

Fig. 1. Sicyonis denisovi sp.n. A — expanded specimen in natural habitat (paratype MIMB 41367); B - the same specimen collected by manipulator; $\mathrm{C}$ - margin of the same specimen (in aquarium); D - formalinpreserved holotype (MIMB 41366), top view; E - holotype, side view. A-B - photo ROV Comanche 18 NSCMB FEB RAS.

Рис. 1. Sicyonis denisovi sp.n. А — расправленный живой экземпляр (паратип МIMB 41367); В — тот же экземпляр во время сбора; C - маргин того же экземпляра, в аквариуме; D - фиксированный голотип (МIMВ 41366) вид сверху; Е - голотип, вид сбоку. А-В - фото ТНПА Comanche 18 ННЦМБ ДВО РАН.

cles. It usually occupies about one fifth of the thickness of the mesogloea (up to $1 / 10$ in more strongly contracted specimens). The sphincter is distinctly alveolar, with individual muscle meshes being small and rather well spaced, longitudinally stratified (Fig. $2 \mathrm{C}, \mathrm{D})$. The longitudinal muscles of the tentacles are mesogloeal and rather weak, evenly developed on the oral and aboral sides and along the length of the tentacles (Fig. 4D, E). The radial muscles of the oral disc are mesogloeal and very strong. They are arranged into thick separate bundles running over each exo- and endocoel (Fig. 4C).

The mesenteries are divisible into two groups: stronger, as a rule sterile, filament-bearing mesen- 


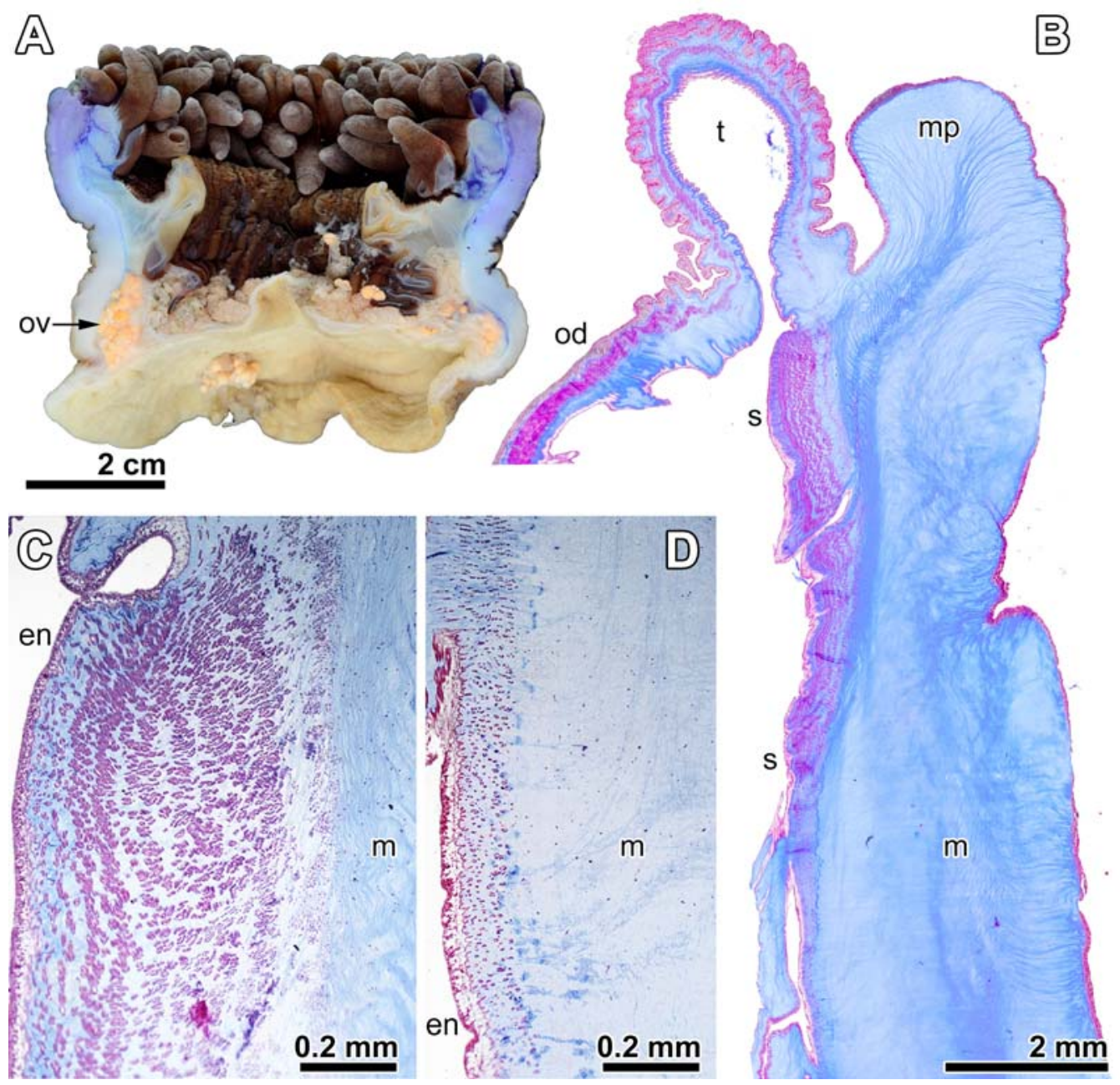

Fig. 2. Sicyonis denisovi sp.n., holotype MIMB 41366. A - longitudinal section of the whole specimen; $\mathrm{B}$ - longitudinal section through the distal part of column; C - distal part of the sphincter; D - proximal part of the sphincter.

Abbreviations: en — endoderm; $\mathrm{m}$ - mesogloea; $\mathrm{mp}$ - marginal projection of the column; od — oral disc; ov — ova; $\mathrm{s}$ - sphincter; $\mathrm{t}$ - tentacle.

Рис. 2. Sicyonis denisovi sp.n., голотип МІМВ 41366. А - продольный срез; В - продольный срез через верхнюю часть колюмна; C - дистальный конец сфинктера; D - проксимальная часть сфинктера.

Сокращения: en — энтодерма; $\mathrm{m}$ - мезоглея; $\mathrm{mp}$ - маргинальный выступ колюмна; od — оральный диск; ov яйца; s - сфинктер; $\mathrm{t}$ - щупальце.

teries present along the whole length of the column, and smaller fertile mesenteries of the last cycle without filaments located in the proximal half of the column. Stronger mesenteries are divisible into 1) perfect pairs (both mesenteries are attached to the actinopharynx), 2) unequal pairs (one mesentery is attached to the actinopharynx, another not reaches it) and 3) imperfect pairs which reach the oral disc but not the actinopharynx. The first (six pairs) and the second (12 pairs) cycles are composed by perfect pairs (occasionally unequal pair may present in the second cycle); the third cycle may be represented by perfect, unequal and imperfect pairs; the fourth cycle has unequal and imperfect pairs.

The arrangement of the mesenterial cycles is hard to reveal. Most probably the arrangement of the 

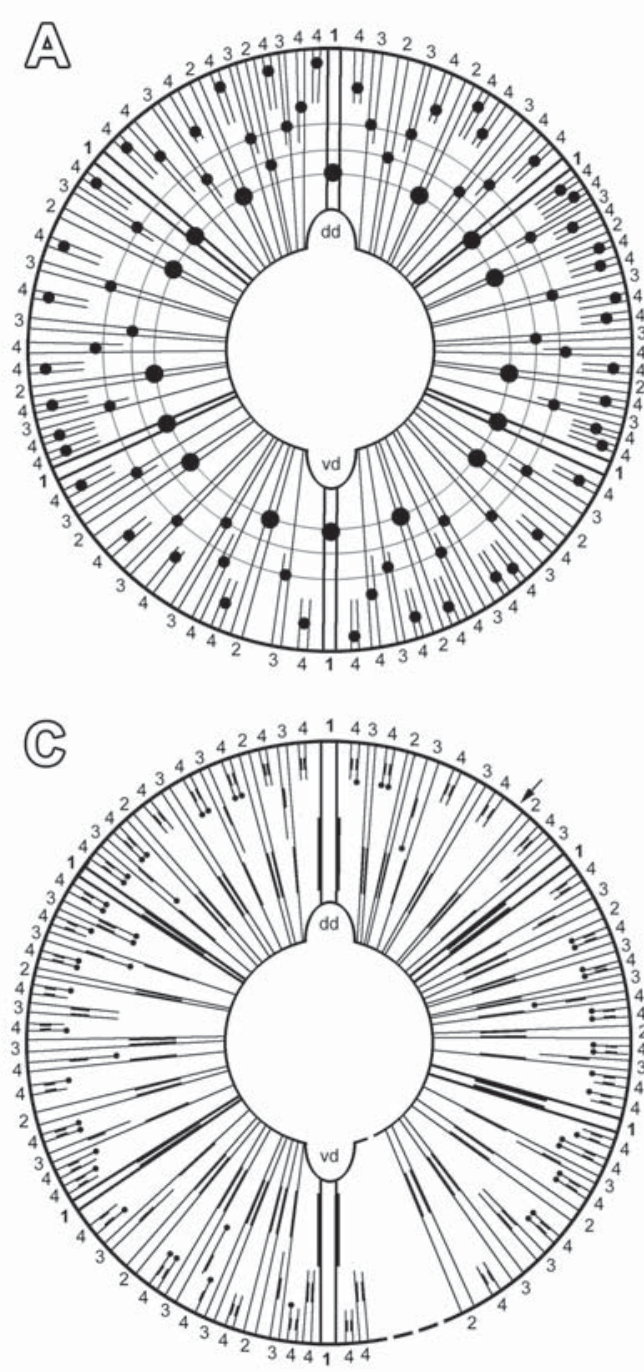

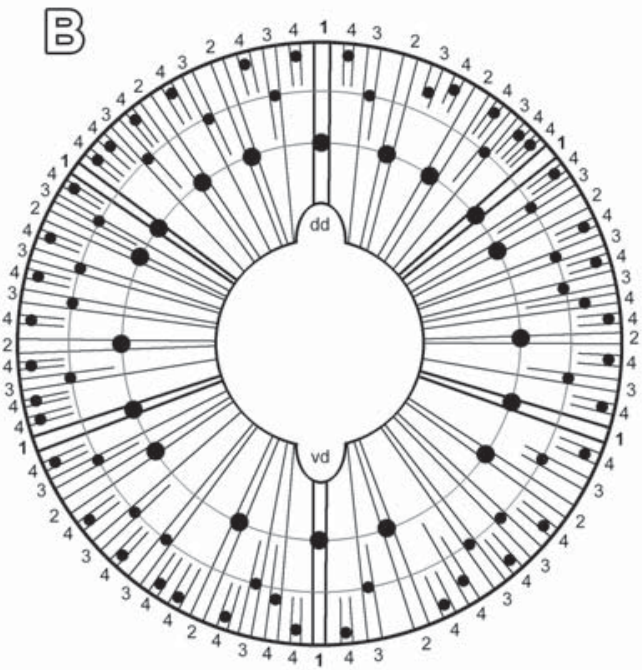

Fig. 3. Sicyonis denisovi sp.n., arrangement of the mesenteries and tentacles. A - paratype MIMB 41367; B - paratype MIMB 41371; C — paratype MIMB 41368.

The youngest (fifth) cycle of fertile mesenteries and exocoelic tentacles of the last cycle not shown; arrow points to the locality of the single mesentery of the fifth fertile cycle which has trilobate filament. Numbers indicate cycle number of mesenterial pairs. Tentacles are marked by black dots between the mesenteries (on Figures A and B). Male gonads on filament-bearing mesenteries of third and fourth cycles are marked by small black circles on the end of the mesenteries (on Figure C). Abbreviations: dd "dorsal" directives; vd - "ventral" directives.

Рис. 3. Sicyonis denisovi sp.n., схемы организации мезентериев и щупалец. А - паратип МIMB 41367; В — паратип MIMB 41371; C —паратип MIMB 41368.

Последний (пятый) цикл фертильных мезентериев и экзоцельные щупальца последнего цикла не обозначены; стрелкой указано местонахождение единственного мезентерия пятого, фертильного, цикла с трилобатным филаментом. Номера мезентериальных циклов подписаны цифрами. Щупальца показаны черными кружками между мезентериями (рисунки А и В). Мелкие чёрные кружки на концах мезентериев обозначают наличие мужских гонад на филаментнесущих мезентериях третьего и четвертого циклов (рисунок C). Сокращения: dd “дорсальные” направляющие пары мезентериев; vd - “вентральные” направляющие пары мезентериев.

mesenterial cycles is a result of combined of a usual for most Actiniaria development of the mesenterial pairs (with multiplication of the meristematic zones between the pairs of the preceding cycles) and bilateral mode of the development of the mesenterial pairs. The bilateral mode is revealed here in common duplications of the pairs of one cycle (starting from the second cycle) and in the presence of pairs with unequally developed mesenteries where one mesentery is perfect while its partner is imperfect, a feature characteristic for exocoelactid anemones with bilat- eral arrangement of the mesenteries. The duplications are not present in the last fertile cycle of filament-lacking mesenteries. Apparently these mesenteries are formed only after formation of all preceding sterile cycles, and, probably, the anemone is sterile until all mesenterial cycles are completely formed (confirmed by Carlgren, 1921: 220 for small sterile specimen of $S$. variabilis Carlgren, 1921 in which the last cycle of the mesenteries at base are very small and sterile). Younger cycles are not arranged according the Actinostola-rule, but there is a 


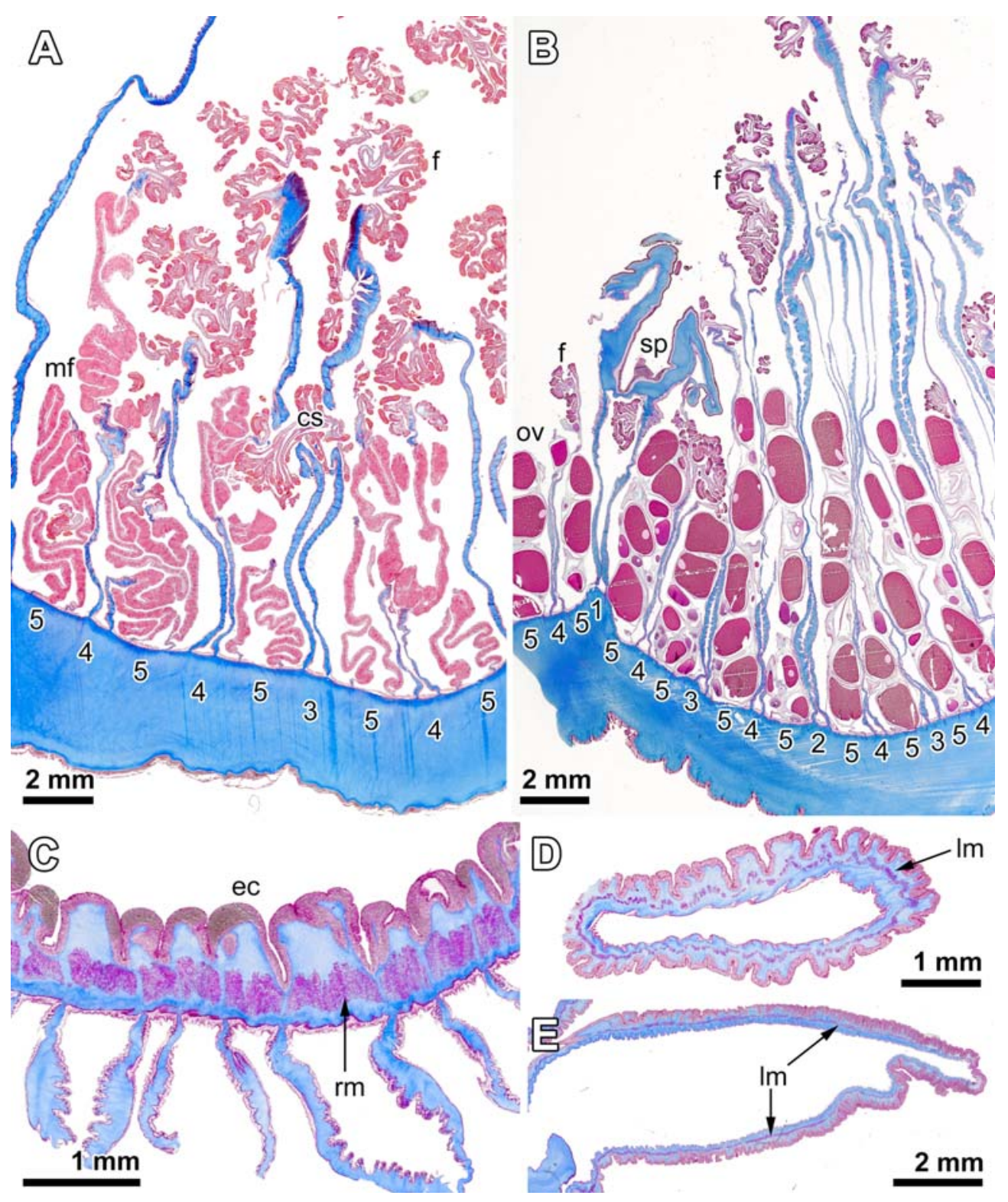

Fig. 4. Sicyonis denisovi sp.n. A - transverse section through the column, male specimen; B - transverse section through the column, female specimen; $\mathrm{C}$ - longitudinal section through the oral disc; $\mathrm{D}$ transverse section through the tentacle; E - longitudinal section through the tentacle. (A - paratype MIMB 41368; B-E - holotype MIMB 41366).

Abbreviations: ec - ectoderm; cs - central stoma; $\mathrm{f}$ - filaments; $1 \mathrm{~m}$ - longitudinal mesogloeal muscles of the tentacles; $\mathrm{mf}$ - male follicles; ov — ova; $\mathrm{rm}$ - radial muscles of the oral disc; $\mathrm{sp}$ - siphonoglyph. Numbers indicate cycle number of mesenterial pairs.

Рис. 4. Sicyonis denisovi sp.n. A — поперечный срез через колюмн, самец: В - поперечный срез через колюмн, самка; C - поперечный срез через оральный диск; D - поперечный срез через щупальце; Е - продольный срез через щупальце. (А - паратип MIMB 41368; B-E — голотип MIMB 41366). Сокращения: ес - эктодерма; cs - центральная стома; $\mathrm{f}$ - филаменты; $\mathrm{lm}$ - продольная мезоглеальная мускулатура щупалец; $\mathrm{mf}$ - семенники; ov — яйца; rm - радиальная мускулатура орального диска; $\mathrm{sp}$ сифоноглиф. Цифрами обозначены номера циклов мезентериальных пар. 

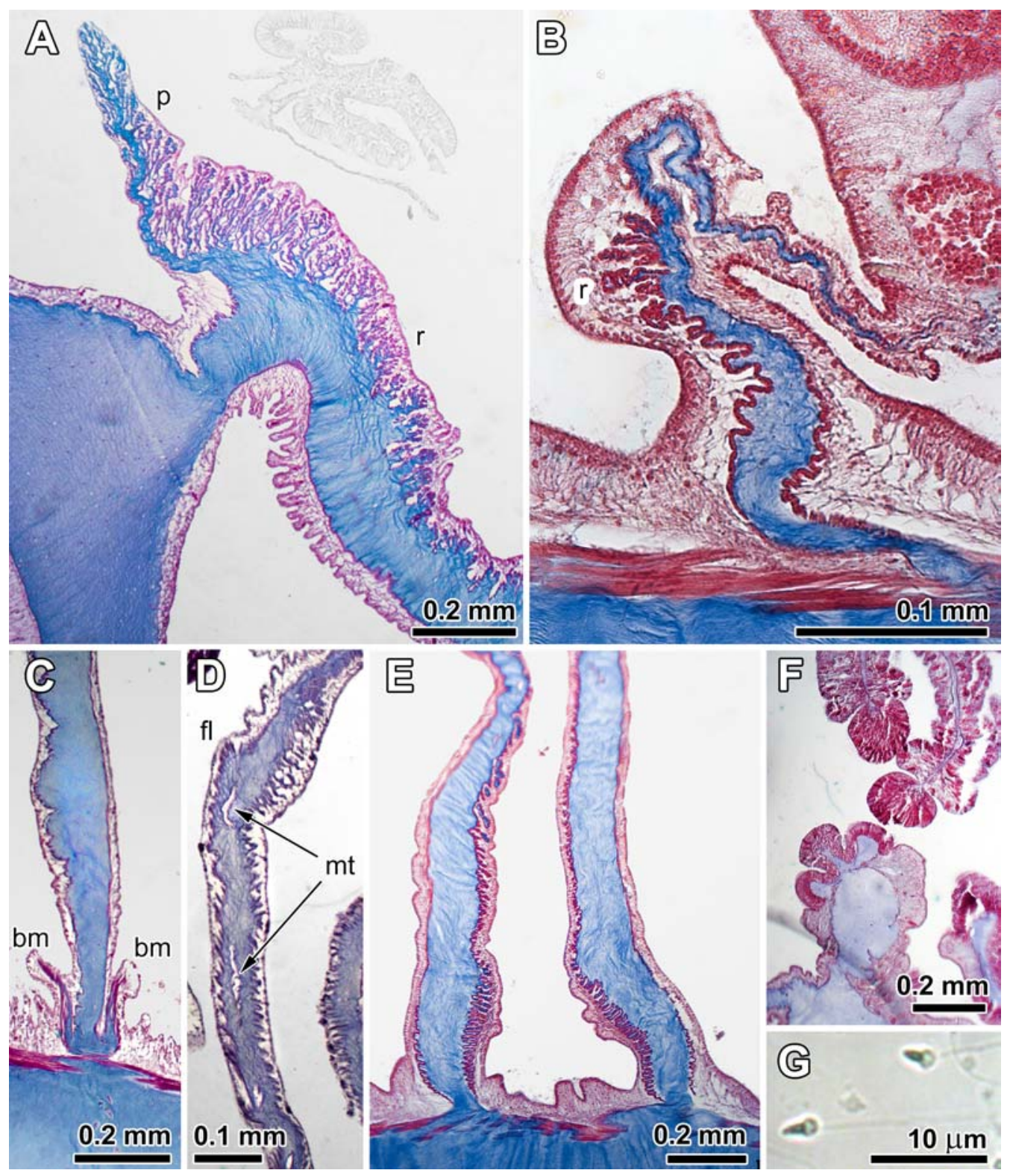

Fig. 5. Sicyonis denisovi sp.n. A - retractor of the directive mesentery; B — the mesentery of the last (fifth) cycle; C - basilar muscles; D - parieto-basilar part of the mesentery of the fourth cycle; E - parietal part of stronger mesenteries; F - unilobate (on the top) and trilobate filaments; G - spermatozoa. (A, C, D holotype MIMB 41366; B, E-G - paratype MIMB 41368).

Abbreviations: $\mathrm{bm}$ - basilar muscles; $\mathrm{fl}$ - parieto-basilar flap; $\mathrm{mt}$ - meshes of transverse muscles in the middle of the mesogloea of the mesentery; $\mathrm{p}$ - the pennon of the retractor; $\mathrm{r}$ - retractor.

Рис. 5. Sicyonis denisovi sp.n. А - ретрактор мезентерия первого цикла; В - мезентерий последнего, пятого, цикла; C - базальные мускулы; D - парието-базилярная часть мезентерия 4 цикла; Е париетальная часть сильных мезентериев; F - филаменты трилобатные (внизу) и унилобатные (вверху); G - сперматозоиды. (А, C, D - голотип MIMB 41366; B, E-G - паратип MIMB 41368). Сокращения: $\mathrm{bm}$ - базальная мускулатура; $\mathrm{fl}$ - парието-базилярный выступ; $\mathrm{mt}$ - альвеолы с поперечной мускулатурой в толще мезоглеи мезентериев; $\mathrm{p}$ - выступ ретрактора; $\mathrm{r}$ - ретрактор. 
regularity in the unequal pairs resembling the Actinostola-rule as in exocoelactids, when imperfect mesentery in each cycle is closer to a pair of the preceding cycle (see Sanamyan, Sanamyan, 2019), i.e. the retractor of the perfect mesentery is faced to the preceding cycle (although a pair of the next cycle is often present between the pairs of these two cycles - a result of combination of two modes of development of the mesenteries). There is a bilateral symmetry in some specimens in the arrangement of the mesenteries, especially in two first cycles, in relation to the directive plane. In the next cycles of the stronger (sterile) mesenteries the symmetry is not evident because of duplication or absence of some pairs and variability in development of mesenteries in pairs from perfect to unequal or imperfect. As a result, at first glance, the arrangement of the mesenteries seems to be irregular (Fig. 3).

The assignment of the mesenterial pairs to a particular cycle may be revealed by a position of an endocoelic tentacle, corresponding to a pair, on the oral disc. The specimen MIMB 41371 has 18 tentacles of the inner cycle: six of them correspond to six mesenterial pairs of the first cycle, and 12 tentacles correspond to the mesenterial pairs of the second cycle (they are duplicated in all six primary exocoels, Fig. 3B). The total number of the tentacles in this specimen is 158 and the mesenteries are distributed in five cycles in a following way: $6+12+22+39+$ $79=158$ pairs (Fig. 3B). Photographed by ROV paratype (MIMB 41367) has only 16 tentacles of the inner cycle (Fig. 1A) because two tentacles, located symmetrically on each side of the "dorsal" directives, belong to the next (the second) tentacular cycle, although correspond to the mesenterial pairs of the second cycle (Fig. 3A). The total number of the tentacles in this specimen is 176 in five cycles and the mesenteries are distributed in five cycles: $6+12+$ $22+48+88=176$ pairs (Fig. 3 A). The mesenteries of the third cycle in these specimens are represented by three pairs in the "dorsal" primary exocoels (between the pairs of the first and the second cycle) and by four pairs in the lateral and "ventral" exocoels (with the duplications in middle of the exocoels between the pairs of the second cycle Fig. 3A, B). This arrangement again shows a bilateral symmetry of the specimens in relation to the directive plane. A larger specimen (MIMB 41368) has 213 tentacles and more numerous mesenteries of the third order: four pairs in all primary exocoels (including "dorsal" exocoels), with duplications in the middle of the exocoels between the pairs of the second cycle, and an additional pair in one of the lateral exocoels between the pairs of the first and the second orders (Fig. 3C).
Longitudinal muscles of the mesenteries are diffuse, continue along the whole width of the mesentery and form small retractor on its adaxial (close to actinopharynx and filaments) side (Fig. 4A, B). Muscle processes on retractors are weakly branched, $100-200 \mu \mathrm{m}$ in length. On the older cycles, especially on the directives, the retractors may have a pennon (Fig. 5A). Parieto-basilar muscles may form a small flap from 40 to $400 \mu \mathrm{m}$ in length on the older cycles of the mesenteries. A chain of small muscle meshes continues from parieto-basilar flap to the wall of the column in the middle of the mesenterial mesogloea (Fig. 5D). The depression of the flap is often connected with the last mesh of this chain. According to Carlgren (1893: 80) these muscle meshes contain fibres of transverse mesenterial muscles which are immersed into the mesogloea. In the parietal part of the mesenteries the muscles are better developed on the side of the retractor muscle: they have longer and more branched processes and continue much farther in adaxial direction than on the opposite side of the mesentery. (Fig. 5E). Parieto-basilar and longitudinal muscles poorly developed on the mesenteries of the last (fertile) cycle, but longitudinal muscles occasionally form small retractors (Fig. 5B). Mesogloea of the mesenteries near trilobate filaments is significantly thicker (to $200 \mu \mathrm{m}$ ) than the mesogloea near the unilobate filaments $(5-10 \mu \mathrm{m}$, Fig. 5F). Basilar muscles well-developed (Fig. 5C).

Perfect mesenteries have oral stoma $1.5-3 \mathrm{~mm}$ in diameter. In the region of margin mesenteries have no stoma, it is displaced in proximal direction and situated on the level of the middle part of the column (Fig. 4A) and is in the middle of the width of all filament-bearing mesenteries. On the older cycles the stoma is larger $(1-6 \mathrm{~mm})$ and positioned closer to the actinopharynx, while on younger cycles it has smaller diameter (no more than $1 \mathrm{~mm}$ ) and located closer to the body wall. Arellano, Fautin (2001: 650) in the description of Exocoelactis actinostoloides (Wassilieff, 1908) stated that "the center of some complete mesenteries perforated by a stoma" but incorrectly interpreted this "central stoma" as "atypically positioned oral stoma" although in some mesenteries they found typically located oral stomata while the marginal stomata were not found. Actually this is atypically positioned marginal (not oral) stoma. We prefer to retain a name "central stoma" for it because it is located on a significant distance from the margin and cannot be named "marginal stoma".

Among five collected specimens one is male and four are females. Ova are large, up to $2 \mathrm{~mm}$ in diameter. Male follicles $50-500 \mu \mathrm{m}$ in diameter. Spermatozoa are radially symmetrical, $3-3.2 \times 1.5-$ $2 \mu \mathrm{m}$ (Fig. 5G). In rare cases the ova are developed 


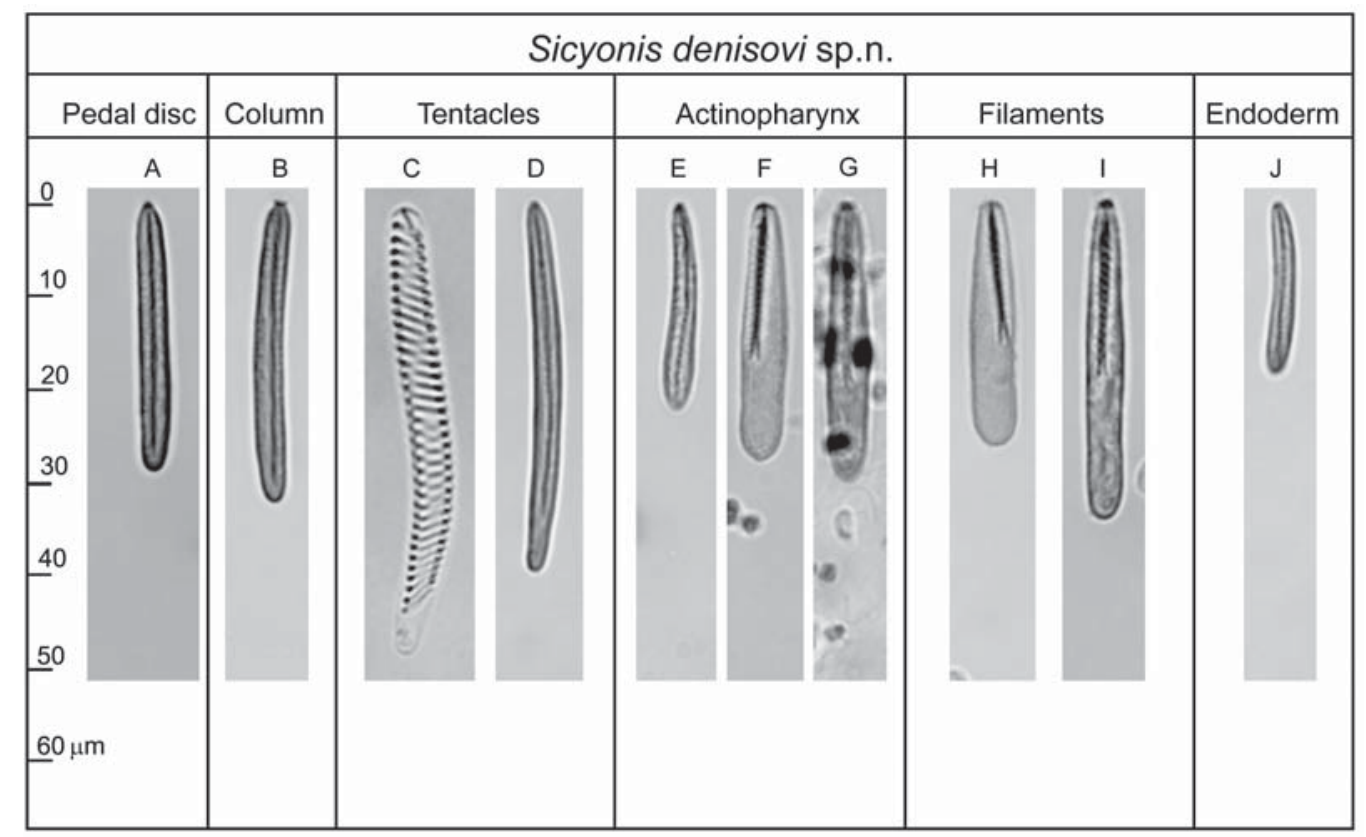

Fig. 6. Sicyonis denisovi sp.n., distribution of cnidae (see Table 1 for size ranges).

Pис. 6. Sicyonis denisovi sp.n., распределение книд (размеры указаны в табл. 1).

on the youngest filament bearing mesenteries of fourth cycle: one such mesentery has ova in the specimen MIMB 41372 and one pair of mesenteries in the holotype (MIMB 41366) (Fig. 4B). The male specimen (MIMB 41368) has male follicles, sometimes numerous and well developed, on a half of imperfect filament-bearing mesenteries (the fourth and the third cycles), including five mesenteries of unequal pairs (Figs 3C, 4A): among 104 imperfect filament-bearing mesenteries at least 56 are fertile, including one mesentery of imperfect pair of the fourth cycle which has abundantly developed male follicles but abnormally present only in distal part of the column and continues along the whole oral disc and not present in the proximal part of the column where gonads of all fertile mesenteries of the last cycle are located (Fig. 3C). In the last (fifth) fertile cycle the filaments are not present with the exception of one case: male specimen has short trilobate filament on one mesentery (note that this is not the same condition as in Parasicyonis where all mesenteries of the last cycle have filaments). It may be speculated that the development of gonads on many filamentbearing mesenteries in penultimate cycles in male specimens is a result of selection under conditions of sparse distribution of the specimens and a low number of males and the need of increased production of the sperm for better success in fertilization of eggs of the females in the area.

Cnidom includes spirocysts, basitrichs, $p$-mastigophores $\mathrm{A}$ and $p$-mastigophores B1 (Table 1, Fig. 6). A narrow $(100-200 \mu \mathrm{m})$ band of the densely packed basitrichs runs in the ectoderm along the limbus. Basitrichs in this region are larger (21-41 $\times$ 2.5-3.5 $\mu \mathrm{m})$, than in the middle part of the column $(21-32 \times 2.5-3.5 \mu \mathrm{m})$. Basitrichs on the tip of the tentacles are longer $(34-47 \times 2.5-3.5 \mu \mathrm{m})$ than in the bases of the tentacles and on the oral disc (22-42 $\times$ 2-3.5 $\mu \mathrm{m})$. Spirocysts are spread on margin on some distance (up to $4-5 \mathrm{~mm}$ ) from the bases of the tentacles, they are common around the bases of the tentacles and gradually become sparse on a distance from them. All spirocysts on the tips of the tentacles are of gracile type (with the tubule laid in a regular spiral). Some spirocysts in the bases of the tentacles, oral disc and margin have irregularly coiled tubule and resemble robust type. However, it is not possible to divide spirocysts in gracile and robust type because there are many transitional forms in which only some turns are laid irregularly in capsule. Most probably the spirocysts of irregularly laid tubule do not belong to a separate type of robust spirocysts which are characteristic for Hormathiidae because irregularly coiled tubules occur in the present spe- 
cies only in some larger capsules $(41-64 \times 5-7.5 \mu \mathrm{m}$ for "robust" spirocysts, and $19-74 \times 2-6.5 \mu \mathrm{m}$ for gracile spirocysts), while in hormathiid spirocysts the tubule is irregularly laid in the small capsules too. Cnidoglandular tracts of trilobate filaments and the endoderm near them contain sparse basitrichs (14$19 \times 2-3 \mu \mathrm{m})$. In unilobate filament $p$-mastigophores A (Fig. $6 \mathrm{H}$ ) and $p$-mastigophores B1 (Fig. 6 I) are present in the cnidoglandular tracts while the basitrichs revealed in macerated samples of filaments are present in widened endoderm of the digestive region of the mesentery near the cnidoglandular tracts; they are the same as in the other endoderm (Fig. 6J) but occur more often here (95 cnidae measured). The endoderm of the digestive region of the mesenteries near the cnidoglandular tracts of unilobate filaments contains remnants of food particles - hydrozoan nematocysts, sometimes very large, indicating that intracellular digestion occurs here. All basitrichs and $p$-mastigophores B1 in the actinopharynx and filaments are stained by basic dyes (toluidine blue) in contrast with spirocysts and $p$-mastigophores A. Occurrence of $p$-mastigophores $\mathrm{A}$ and $\mathrm{B} 1$ in the actinopharynx and filaments varies in different specimens. In particular, the occurrence of $p$-mastigophores $\mathrm{A}$ in the actinopharynx varies from "common" (in holotype MIMB 41366 and in paratype MIMB 41367) to "rare" (in MIMB 41368, MIMB 41371 and MIMB 41372); in filament from “common" (in holotype MIMB 41366, MIMB 41371 and MIMB 41372) to "few" (in MIMB 41367 and MIMB 41368). The occurrence of $p$-mastigophores B1 in the actinopharynx varies from "common" (in holotype MIMB 41366) to "very rare" (in MIMB 41367, MIMB 41368 and MIMB 41372) and they are not found in MIMB 41371; in filaments they are "numerous" (in holotype MIMB 41366 and MIMB 41371) to "common" (in MIMB 41367, MIMB 41368 and MIMB 41372). Mastigophores of each type in the actinopharynx and filaments are similar in size and details of the structure. $P$-mastigophores $\mathrm{A}$ (Fig. 6F, H) have thin-walled capsule without apical flap, the length of the shaft in undischarged capsule is $12-19 \mu \mathrm{m}$, discharged shaft is $20-26 \mu \mathrm{m}$ in length and about $2 \mu \mathrm{m}$ thick; the shaft has $12-19$ spiral turns of spines which are about $3 \mu \mathrm{m}$ long and perpendicular to the shaft; the terminal tubule is thin and short, up to $48 \mu \mathrm{m}$, i.e. up to two lengths of the capsule. $P$ mastigophores B1 (Fig. 6G, I) have thick-walled capsule, three-lobed apical flap, the length of the shaft in the capsule is $12-21 \mu \mathrm{m}$, discharged shaft is $19-28 \mu \mathrm{m}$ in length and $1.2-1.5 \mu \mathrm{m}$ thick, the shaft has 11-19 turns of spines which are 4-5 $\mu \mathrm{m}$ in length and attached at an angle to the shaft with free ends tilted toward the capsule; the terminal tubule long, its measured length is up to $175 \mu \mathrm{m}$, i.e. six times longer than the capsule. $P$-mastigophores A and B1 are similar in the size of the capsule, the length both, discharged and undischarged shaft (it becomes about 1.5 times longer in discharged condition) and the number of the turns of the spines on the shaft.

HABITAT. The species was recorded at bathyal depths attached to stones or on firm bottom consisting of mixture of small stones, gravel and sediment. The specimens are found scattered, on large distance one from another, they do not occur in groups, but this species appear to be most common large species of sea anemones on these depths (collected specimens are from 386, 981, 986 and $1061 \mathrm{~m}$ ).

ETYMOLOGY. The species is named after Vitaly A. Denisov, a head of a group worked with ROV Comanche 18 NSCMB FEB RAS in 75 and 82 cruises of RV Akademik M.A. Lavrentyev.

REMARKS. The most important features, distinguishing the present species from other Sicyonis species are: very numerous tentacles (158-213) arranged in four or five cycles on the outer half of the oral disc; five cycles of the mesenteries; thin-walled tentacles without basal mesogloeal thickenings. Unlike all other species described in the present work this species has $p$-mastigophores B1 not only in the filaments, but also in the actinopharynx.

None of three species previously reported from Pacific bear a resemblance with $S$. denisovi sp.n. Sicyonis tubulifera, a poorly known species described off the east coast of Japan $\left(34^{\circ} 37^{\prime} \mathrm{N}, 140^{\circ} 32^{\prime} \mathrm{E}\right.$, about $3400 \mathrm{~m}$ ), has long tentacles and its sphincter is much stronger than in S. denisovi sp.n., it "contracts the wall so strongly that the surface becomes arranged in ridge-like, projecting folds" (Hertwig, 1882: 129). Sicyonis careyi is based on numerous specimens from East Pacific (550-3700 m). It has significantly fewer tentacles (58-80, arranged in three cycles) and mesenteries (about 80 pairs) than $S$. denisovi sp.n. They cannot be conspecific. Sicyonis heliodiscus from East Pacific is disc-shaped species bearing no resemblance with $S$. denisovi sp.n. Among North Atlantic species only $S$. gossei has numerous tentacles (151 in the only one known specimen), but, in contrast with the present species, their mesogloea is extremely thick, as in most other Sicyonis species.

\section{Sicyonis kuznetsovi sp.n. Table 2; Figs 7-11.}

MATERIAL EXAMINED. Holotype MIMB 41369, RV Akademik M.A. Lavrentyev, 75 cruise, St. 17, sample 4, 27 June 2016, NW Pacific, the south-west Bering Sea, in the northern slope of the 
Table 2. Size ranges (length $\times$ width, in microns) and distribution of cnidae of Sicyonis kuznetsovi sp.n. Letters in brackets correspond to letters in Fig. 11. Таблица 2. Размеры (длина × ширина, в микронах) и распределение стрекательных капсул Sicyonis kuznetsovi sp.n. Буквы в скобках соответствуют буквам на рис. 11.

\begin{tabular}{lll}
\hline Body region & Cnidae & Size ranges $(\mu \mathrm{m})$ \\
\hline Pedal disc & (A) basitrichs (few) & $19-26 \times 2.5-3$ \\
\hline Column & (B) basitrichs (common) & $21-30 \times 2.5-3.5$ \\
\hline \multirow{2}{*}{ Tentacles } & (C) spirocysts (very numerous) & $28-86 \times 3-5.5$ \\
& (D) basitrichs (common) & $36-51 \times 3-3.5$ \\
\hline \multirow{2}{*}{ Actinopharynx } & (E) basitrichs (numerous) & $18-31 \times 2-3$ \\
& (F) $p$-mastigophores A (few) & $27-33 \times 4.5-6$ \\
\hline \multirow{2}{*}{ Filaments } & (G) $p$-mastigophores A (numerous) & $25-33 \times 4.5-6$ \\
& (H) $p$-mastigophores B1 (very rare) & $26-36 \times 4-5$ \\
\hline Endoderm & (I) basitrichs (see text) & $15-25 \times 2-3$ \\
\hline
\end{tabular}
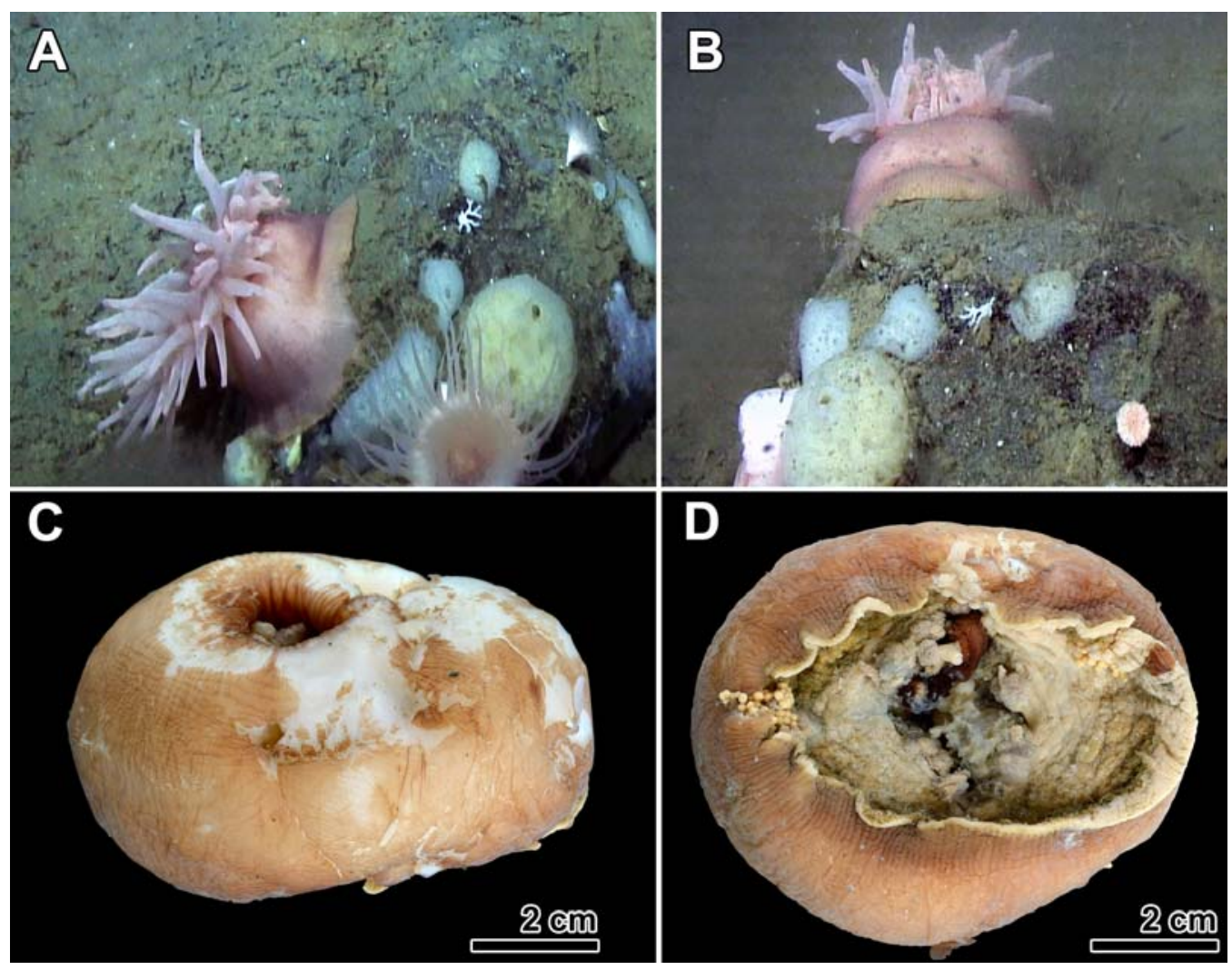

Fig. 7. Sicyonis kuznetsovi sp.n. A-B - specimen in natural environment (holotype), photo ROV Comanche 18 NSCMB FEB RAS; C - preserved holotype, side view; D - preserved holotype, pedal disc.

Рис. 7. Sicyonis kuznetsovi sp.n. А-В - живой экземпляр (голотип), фото ТНПА Comanche 18 ННЦМБ ДВО РАН; С — фиксированный голотип, вид сбоку; D — фиксированный голотип, педальный диск. 


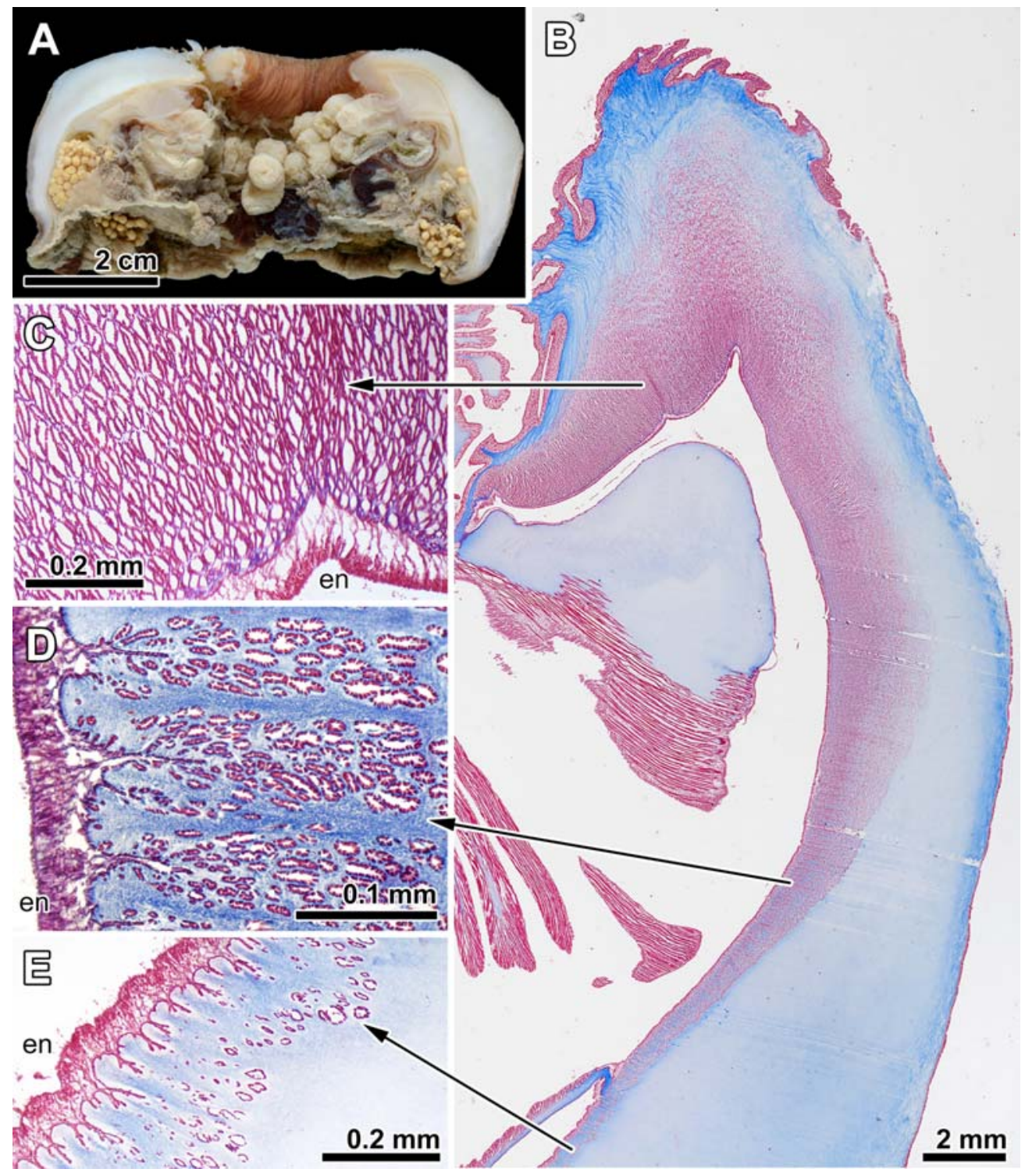

Fig. 8. Sicyonis kuznetsovi sp.n. A - longitudinal section of the whole specimen; B - longitudibal section through the distal part of column; C - distal part of the sphincter; D - middle part of the sphincter; E proximal part of the sphincter.

Abbreviations: en - endoderm.

Рис. 8. Sicyonis kuznetsovi sp.n. А - продольный срез; В - продольный срез через верхнюю часть колюмна; C - дистальный конец сфинктера; D - средний участок сфинктера; E — проксимальный участок сфинктера.

Сокращения: en - энтодерма.

Volcanologists Massif, $55.4553^{\circ} \mathrm{N}, 167.2668^{\circ} \mathrm{E}$, $2131 \mathrm{~m}$, ROV Comanche 18 NSCMB FEB RAS, one specimen.

DESCRIPTION. One specimen was photographically documented by ROV and collected. In live the column is low and wider proximally than distally, about $12 \mathrm{~cm}$ in the greatest diameter and about $7 \mathrm{~cm}$ in height. The diameter expanded tentacular crown is estimated as $18-20 \mathrm{~cm}$. Preserved and contracted specimen is dome-shaped, $7 \mathrm{~cm}$ in diam- 

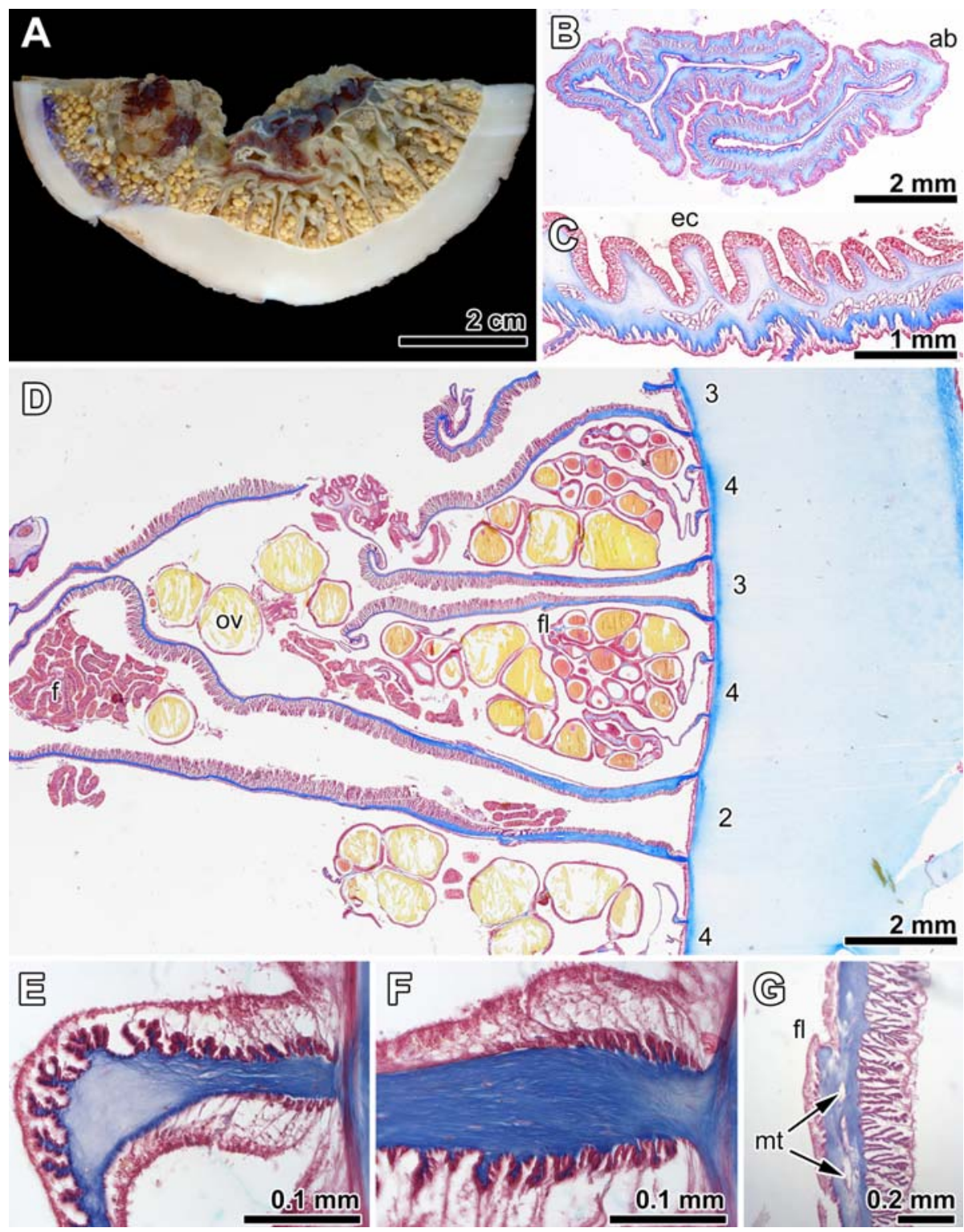

3

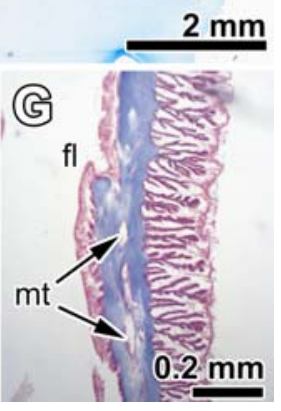

Fig. 9. Sicyonis kuznetsovi sp.n. A - transverse section of the half of column; B - transverse section of the tentacle; $\mathrm{C}$ - transverse section of the oral disc; $\mathrm{D}$ - transverse section of the column; $\mathrm{E}$ - parietal part of the fertile mesentery; F - parietal part of the sterile mesentery of the second cycle; G - parieto-basilar part of the mesentery of the second cycle.

Abbreviations: ab - aboral side of the outer tentacle; ec — ectoderm; $\mathrm{f}$ - filament; fl — parieto-basilar flap; $\mathrm{mt}$ meshes of transverse muscles in the middle of the mesogloea of the mesentery; ov - ova. Numbers indicate cycle number of mesenterial pairs.

Рис. 9. Sicyonis kuznetsovi sp.n. А — поперечный срез через половину колюмна; В - поперечный срез через щупальца; C - поперечный срез через оральный диск; D - поперечный срез через колюмн; Е - париетальная часть фертильного мезентерия; F - париетальная часть стерильного мезентерия второго цикла; $\mathrm{G}$ - парието-базилярный участок мезентерия второго цикла.

Сокращения: ab - аборальная сторона наружного щупальца; ес - эктодерма; $\mathrm{f}$ - филаменты; $\mathrm{fl}$ - париетобазилярный выступ; $\mathrm{mt}$ - альвеолы с поперечной мускулатурой в толще мезоглеи мезентериев; ov — яйца. Цифрами обозначены номера циклов мезентериальных пар. 


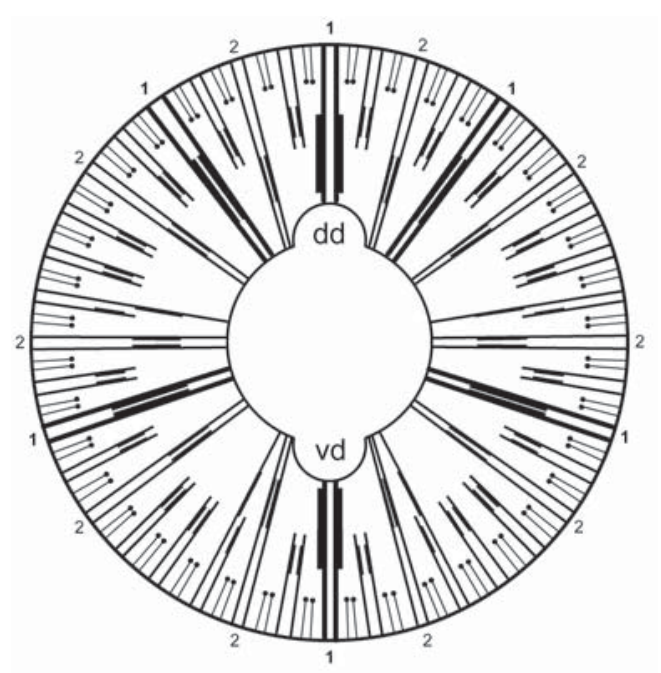

Fig. 10. Sicyonis kuznetsovi sp.n., arrangement of the mesenteries.

Gonads are marked by small black circles on the end of the mesenteries of the last cycle.

Abbreviations: dd - "dorsal" directives; vd — "ventral" directives. Numbers indicate cycle number of mesenterial pairs.

Рис. 10. Sicyonis kuznetsovi sp.n., организация мезентериев.

Гонады обозначены черными кружочками на концах мезентериев последнего цикла. Сокращения: $\mathrm{dd}-$ “дорсальные” направляющие пары мезентериев; vd “вентральные” направляющие пары мезентериев. Цифрами обозначены номера циклов мезентериальных пар.

eter and $3.5 \mathrm{~cm}$ high. In live the whole specimen was light rose-beige, the tentacles somewhat paler than the column (Fig. 7A, B). In formalin the column is brown due to the colour of the ectoderm, with white patches of mesogloea in the places where the ectoderm is abraded (Fig. 7C). Ectoderm of the pedal disc is beige, paler than the column (Fig. 7D), has remnants of easily peeling cuticle-like film. The tentacles are colourless and the internal lining of the actinopharynx is dark brown (Fig. 8A).

The pedal disc is circular, concave (Fig. 7D). The surface of the column is smooth, with sparse shallow wrinkles in preserved specimen. Mesenterial insertions are visible as shallow longitudinal furrows at the limbus and the proximal part of column. The column is thick-walled, the thickness of the mesogloea is up to $5 \mathrm{~mm}$ in its middle, much thinner at limbus. Ectoderm of column is firm and thin, 40$50 \mu \mathrm{m}$. The distal part of the column can almost completely cover the tentacles (Fig. 7C).

There are about 80 tentacles arranged in at least four cycles on the periphery of the oral disc. All tentacles are of about the same length, slightly tapering, with blunt perforated tips. The mesogloea of the tentacles is not thick and its thickness is the same along the whole length of the tentacle (Fig. 9B). The tentacles have no mesogloeal thickenings at base.

The marginal sphincter muscle is strong, wide distally and tapering in the proximal direction, and rather long (about one third or more of the column height). It's main distal part occupies to $3 / 4$ of the mesogloea thickness (Fig. 8B). It is chiefly mesogloeal, confined to the endodermal side of the mesogloea of column, not separated from the circular endodermal musculature of the column and makes endomesogloeal complex with it. The main distal part of the sphincter is distinctly reticular, especially in its part lying closer to the endodermal side of the mesogloea (Fig. 8C), but muscle meshes become sparser and the structure gradually becomes alveolar in a narrow proximal part of the sphincter and in the middle layers of the mesogloea (Fig. 8D, E). Branches of the endodermal circular muscles continue into horizontal groups of meshes of the sphincter muscle so that horizontal stratification is formed, which is well visible at the middle and proximal parts of the sphincter (Fig. 8D). Actually the sphincter muscle may be called endomesogloeal.

The longitudinal muscles of the tentacles are strong, mesogloeal, almost evenly developed on the oral and aboral sides and along the length of the inner tentacles but weaker on the aboral side of the outer tentacles (Fig. 9B). The radial muscles of the oral disc are mesogloeal, moderately developed (Fig. 9C), not separated from the longitudinal muscles on the oral side of the tentacles.

The mesenteries are divisible into stronger sterile mesenteries which have filaments (40 pairs) and weaker fertile mesenteries of the last cycle which have no filaments (40 pairs). The latter are present only in the proximal half of the column. Sixteen pairs of mesenteries belonging to the first and the second cycles are perfect. In addition, four other pairs are composed of unequally developed mesenteries, one perfect and one imperfect mesentery. Smaller (imperfect) mesentery in these pairs is closer to the nearest pair of the mesenteries of the second cycle. Sixteen perfect pairs suggest that the arrangement of the mesenteries is octomerous. However, after a comparison with the arrangement of the tentacles, the first cycle of which contains six tentacles located closer to the mouth than the other tentacles, we conclude that the first cycle of the mesenteries has six pairs, and the second cycle has 10 pairs: in the lateral and "ventral" primary exocoels the mesenteries of the second cycle are duplicated (Fig. 10). Four pairs composed of unequally developed mesenteries 


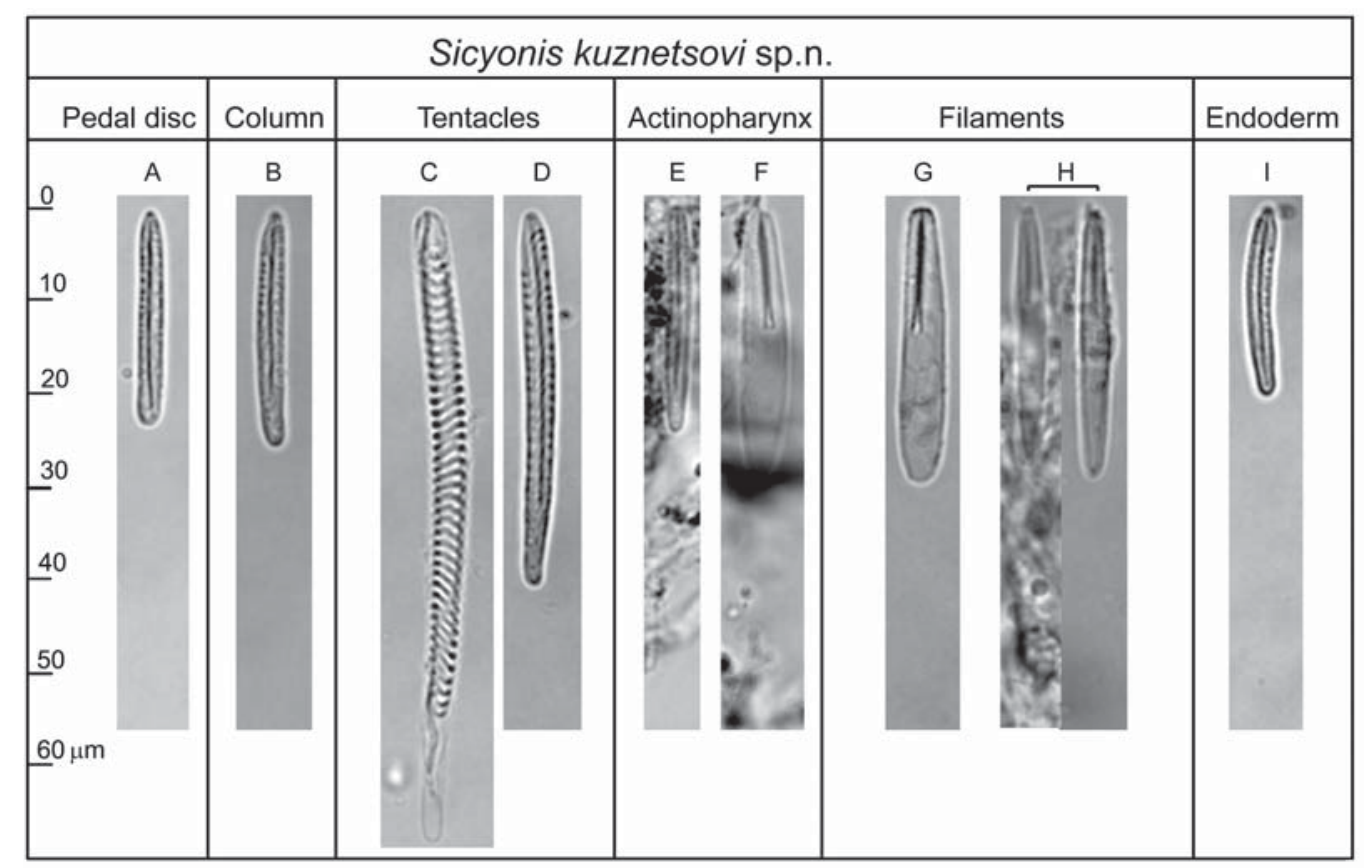

Fig. 11. Sicyonis kuznetsovi sp.n., distribution of cnidae (see Table 2 for size ranges).

Рис. 11. Sicyonis kuznetsovi sp.n., распределение книд (размеры указаны в табл. 2).

are located in the same lateral and "ventral" primary exocoels. Endocoelic tentacles, communicating with these pairs, are located on the oral disc between the tentacles of the second and third cycles. Twenty pairs of the third cycle also peculiarly distributed in two lateral and two "ventral" primary exocoels (Fig. 10). These four primary exocoels contain identical set similarly arranged mesenteries of the second to fourth cycles, which, unlike mesenteries in "dorsal" primary exocoels, are arranged not in a usual way but with some traits resembling bilateral arrangement of the mesenteries in the middle of the exocoels. This is suggested by the duplications in the second and third cycles and the presence of the pairs composed of one perfect and one imperfect mesentery (as in Exocoelactinidae). Thus the whole specimen is bilaterally symmetric in relation to the directive plane. Pairs of the third and fourth cycles are composed of more or less equally developed mesenteries, Actinostolarule cannot be applied to them.

Sterile mesenteries have well developed long diffuse retractors with usually branched muscle processes (Fig. 9D). Their parietobasilar muscles form a short flap (up to $170 \mu \mathrm{m}$ in length). The mesogloea of the mesenteries in the region of parietobasilar muscles contains chains of meshes with muscle fibers (Fig. 9G). Fertile mesenteries have short weak retractors (Fig. 9E), their parietobasilar muscles are very weak. Both sides of the parietal (closer to the body wall) part of the mesenteries have noticeably developed muscles constituting the parietal part of the mesenterial musculature (Fig. 9E, F). On the side of retractor muscle they continue much farther along the mesentery than on the opposite side of the mesentery.

The mesenteries have oral and central stomata (see description of the previous species) about 0.5$1 \mathrm{~mm}$ in diameter. The central stomata are situated on a distance of about $2 \mathrm{~cm}$ from the margin, i.e. in about the middle of the height of the column. The mesogloea of the mesenteries near the trilobate filaments is thick (more than $100 \mu \mathrm{m}$ ), much thicker than near the unilobate filaments $(10-20 \mu \mathrm{m})$.

The gonads, containing large ova up to $1.5 \mathrm{~mm}$ in diameter, are well developed (Fig. 9D).

Cnidom includes spirocysts, basitrichs, $p$-mastigophores A, $p$-mastigophores B1 (Tab. 2, Fig. 11). The most part of the column, apart from its distal part, contains only one type of basitrichs (Fig. 11B). The distal $1.5 \mathrm{~cm}$ of the column, the tentacles and the oral disc contain spirocysts and basitrichs (Fig. 11C, D). Columnar spirocysts are abundant at most distal part of the column near the bases of the tentacles but gradually become sparse proximally. Basitrichs in 
distal part of the column and in the oral disc are smaller $(22-37 \times 2-3.5 \mu \mathrm{m})$, than in the tentacles. Tentacular basitrichs (Fig. 11D) become longer toward the tips of the tentacles, they are 36-47 $\times 3-3.5$ $\mu \mathrm{m}$ in the bases of the tentacles and 40-51 $\times 3-3.5$ $\mu \mathrm{m}$ in their tips. Squash samples from the tentacle tips contain also very rare small basitrichs from the endoderm, which apparently are getting there through the pore at tentacle tip. The endoderm of all parts of the body contains very rare small basitrichs (Fig. 11 I). Ectoderm of the most upper part of the actinopharynx (1-2 $\mathrm{mm}$ from the oral disc) contains occasional sparse spirocysts which not present in other parts of the actinopharynx (confirmed on sections). The cnidoglandular tracts of unilobate filaments contain $p$-mastigophores A and B1 (Fig. 11G, H). Small basitrichs commonly found on the macerated samples of filaments of the same type as in the endoderm (Fig. 11 I, more than 80 cnidae measured), actually not present in the cnidoglandular tracts of unilobate filament, but come from the endoderm of the mesenteries where they are more numerous near the cnidoglandular tracts. The same set of the nematocysts is present in the cnidoglandular tracts of the trilobate filaments ( $p$-mastigophores A and B1 and basitrichs), but the basitrichs here are present also in the cnidoglandular and reticular tracts. $P$-mastigophores A in the actinopharynx and filaments (Fig. $11 \mathrm{~F}, \mathrm{G})$ have thin-walled capsule without apical flap, the undischarged shaft is $12-18 \mu \mathrm{m}$ in length and has 13-16 turns of spines; discharged shaft is $1.5-2$ times longer, up to $2 \mu \mathrm{m}$ thick, the spines are about $2.5 \mu \mathrm{m}$, the terminal tubule short (measured length about $15 \mu \mathrm{m}$, two times shorter than the capsule). $P$-mastigophores B1 (Fig. 11H) are present only in the filaments (17 cnidae measured). They have thick-walled capsule, three-lobed apical flap, the length of the shaft in the capsule is $9-11 \mu \mathrm{m}$ (about one third of the capsule length), V-shaped end of the shaft rarely visible, often the shaft is straight as the stick in the basitrichs. Discharged shaft is $9-13 \mu \mathrm{m}$ in length and about $1 \mu \mathrm{m}$ thick, becomes thinner in the end, has 7-9 turns of rows of spines which are 1.5-2 $\mu \mathrm{m}$ long; terminal tubule thin. All basitrichs and $p$-mastigophores B1 (Fig. $11 \mathrm{H}$ ) are stained by basic stains in contrast with $p$ mastigophores A and spirocysts. Endoderm of the unilobate filaments near the cnidoglandular tracts contains numerous hydrozoan nematocysts, apparently obtained from the prey.

HABITAT. The specimen was attached to a stone at lower bathyal depths. On the same stone near the anemone were found sponges, another anemone (possibly Hormathiidae), a specimen of a scleractinian coral (possibly Caryophyllidae), hydrocoral (Sty- lasteridae) and in the vicinity of the same stone on the muddy bottom were recorded acorn worms (Enteropneusta, fam. Torquaratoridae) and red benthopelagic hydrozoan medusa (Trachymedusae, fam. Rhopalonematidae).

ETYMOLOGY. The species is named after Andrey Kuznetsov who worked with ROV Comanche 18 NSCMB FEB RAS in both 75 and 82 cruises of RV Akademik M.A. Lavrentyev.

REMARKS. Sicyonis kuznetsovi sp.n. resembles Sicyonis denisovi sp.n. in the following features: 1) the tentacles are arranged in more than two cycles; 2) the tentacles are relatively thin-walled without any kind of mesogloeal thickenings; 3 ) the species lives attached to stones (compare with $S$. ingolfi and $S$. titanic sp.n. described below). Morphologically Sicyonis kuznetsovi sp.n. differs from Sicyonis denisovi sp.n. in: 1) significantly fewer mesenteries and tentacles (80 tentacles in Sicyonis kuznetsovi sp.n., 158-213 in Sicyonis denisovi sp.n.); 2) different and much stronger sphincter (compare Figs 2B and. 8B); 3) details of cnidom: Sicyonis kuznetsovi sp.n. has peculiar $p$-mastigophores $\mathrm{B} 1$ in the filaments which differs from $p$-mastigophores B1 in other species. On the underwater photographs these two species may be distinguished by the shape of the tentacles (tips are sharp in Sicyonis denisovi sp.n. and blunt in Sicyonis kuznetsovi sp.n.), their number and colour of the specimens. Very wide sphincter distinguishes this species from all Sicyonis species known from North Atlantic except $S$. haemisphaerica, but the latter species has strong thickening of the mesogloea on aboral sides of the tentacles and in any case the conspecificity of the Pacific and Atlantic species is almost excluded.

The nematocysts termed here $p$-mastigophores B1, resemble basitrichs with short stick $9-11 \mu \mathrm{m}$ in length, that is about one third of the length of the capsule. However, in some of these capsules the stick has funnel-shaped formation at its end as in $p$ mastigophores. It is known that among $p$-mastigophores B1 the capsules with pointed (rather than funnel-shaped) end of the shaft often occur (see Sanamyan, Sanamyan, 2019; Sanamyan et al., 2013). $P$-mastigophores B1, recorded in filaments of many actiniids (see den Hartog, 1987; Sanamyan et al., 2013), also strongly resemble basitrichs and their shaft not always clearly differentiated from the terminal tubule. For example, in Urticina grebelnyi Sanamyan et Sanamyan, 2006 the shaft is several times thicker than the tubule, while in Aulactinia stella (Verrill, 1864) the shaft is of about the same diameter as the tubule (our data). Dunn et al. (1980) reported the same facts for A. incubans Dunn et al., 1980 , these authors identified these capsules as 
Table 3. Size ranges (length $\times$ width, in microns) and distribution of cnidae of Sicyonis ingolfi (based on two specimens). Letters in brackets correspond to letters in Fig. 15. Таблица 3. Размеры (длина $\times$ ширина, в микронах) и распределение стрекательных капсул Sicyonis ingolfi (по двум экземплярам). Буквы в скобках соответствуют буквам на рис. 15.

\begin{tabular}{lll}
\hline Body region & Cnidae & Size ranges $(\mu \mathrm{m})$ \\
\hline Pedal disc & (A) basitrichs (common) & $18-24 \times 2.3-3$ \\
\hline Column & (B) basitrichs (common) & $23-37 \times 2.5-3.3$ \\
\hline \multirow{2}{*}{ Tentacles } & (C) spirocysts (numerous) & $26-75 \times 2.5-6$ \\
& (D) basitrichs (common) & $27-51 \times 2.5-4.5$ \\
\hline \multirow{2}{*}{ Actinopharynx } & (E) basitrichs (common) & $25-37 \times 2.5-4$ \\
& (F) p-mastigophores A (very rare) & $33 \times 4.5$ \\
\hline \multirow{2}{*}{ Filaments } & (G) p-mastigophores A (common) & $25-34 \times 3.5-7$ \\
& (H) p-mastigophores B1 (common) & $22-30 \times 3.5-5$ \\
\hline Endoderm & (I) basitrichs (see text) & $13-22 \times 1.6-2.6$ \\
\hline
\end{tabular}

basitrichs. However, in Urticina, Cribrinopsis Carlgren, 1921, Aulactinia Agassiz in Verrill, 1864 and some other actiniids these capsules, located only in the cnidoglandular tracts of the filaments, belong to the same type. Most probably this is a transitional form between basitrichs and other $p$-mastigophores B (with three-lobed apical flap). $P$-mastigophores B1 in Sicyonis kuznetsovi sp.n. looks as a transitional form between the basitrichs and $p$-mastigophores B1. A very similar nematocyst is reported by Riemann-Zürneck (1991, Fig.1(8)) in the filaments of $S$. biotrans as basitrichs with short stick reaching the middle of the capsule which looks slightly thicker than the stick of other basitrichs and similar in its thickness to the shaft of $p$-mastigophores in the same work (compare figures 1(7) and 1(8) in RiemannZürneck, 1991). P-mastigophores B1 in Sicyonis kuznetsovi sp.n. are very rare; we were able to find only four exploded capsules. They have distally narrowing shaft 9-13 $\mu \mathrm{m}$ in length, i.e. exploded shaft is no more than 2-3 $\mu \mathrm{m}$ longer than unexploded. Also, the presence of these capsules in cnidoglandular tracts of filaments and a general similarity of the cnidom of different species of Sicyonis suggest that they should be identified as $p$-mastigophores B1. The presence of the same set of nematocysts in the cnidoglandular tracts of trilobate filaments and in unilobate filaments may be considered as archaic feature.

Sicyonis ingolfi Carlgren, 1921 Table 3; Figs 12-15, 19B-C.

Sicyonis ingolfi Carlgren, 1921: 217. Molodtsova et al., 2008: 113.
MATERIAL EXAMINED. RV G.O. Sars, MARECO cruise, St. 50/373, 12 July 2004, North Atlantic, Mid-Atlantic Ridge, north of the Azores, $43.0345^{\circ}-43.01463^{\circ} \mathrm{N}, 28.55183^{\circ}-28.56664^{\circ} \mathrm{W}$, 2593-2607 m, trawl, one specimen; St. 73/386, 27 July 2004, North Atlantic, Mid-Atlantic Ridge, northwest of Charlie-Gibbs Fracture Zone, 53.28 $53.25817^{\circ} \mathrm{N}, 35.53417^{\circ}-35.52983^{\circ} \mathrm{W}, 2522-2567$ $\mathrm{m}$, trawl, one specimen.

DESCRIPTION. The specimen from St. 50/373 is $7.5 \mathrm{~cm}$ in diameter and height, male; the specimen from St. $73 / 386$ is $8.6 \mathrm{~cm}$ in diameter and $6.3 \mathrm{~cm}$ height, female. The pedal disc is circular, concave, undamaged (Fig. 12D). Cylindrical column has transverse circumferential furrow in its proximal half (Fig. 12A). The mesogloea of the column is very thick, up to $6 \mathrm{~mm}$ in its middle part (Fig. 12C). The margin and the limbus have longitudinal furrows along the insertions of the mesenteries, they are two times more numerous on the limbus than on the margin (Fig. 12B, D). The remaining surface of the column is almost smooth, with small wrinkles. The number of the marginal mesogloeal swellings between the furrows corresponds to the number of the tentacles, these swellings are probably caused by contraction and form a distinct marginal ridge (Figs 12B, 13B).

The tentacles are not covered by distal part of the column (Fig. 12B), arranged in two cycles on the margin of the oral disc, inner and outer of the same size (about $1.5 \mathrm{~cm}$ ), 58 tentacles in specimens from St. 50/373 and about 68 in specimen from St. 73/386. The tentacles are thick at bases (up to $0.8 \mathrm{~cm}$ in diameter), taper to pointed tips, with large terminal apertures. 


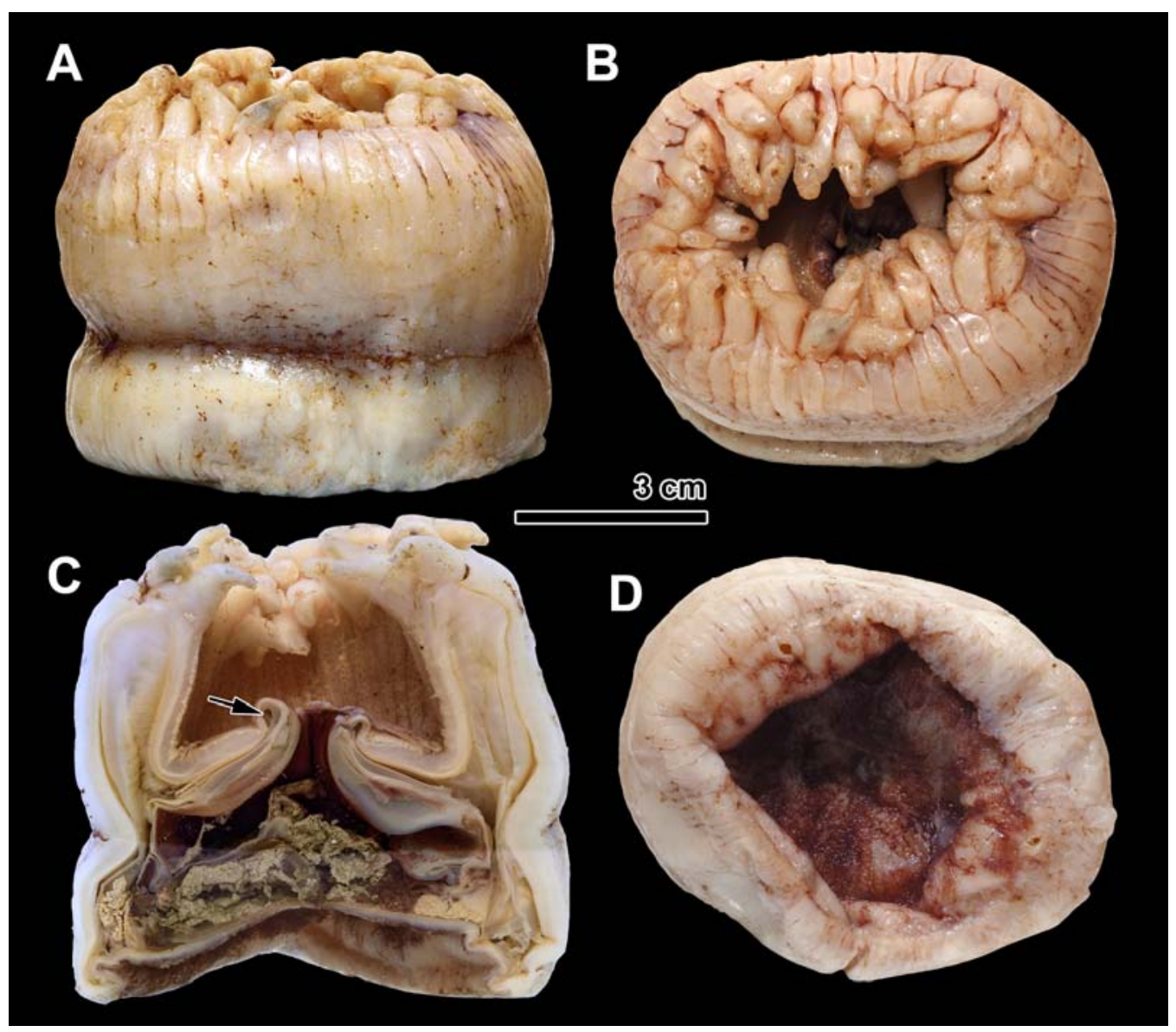

Fig. 12. Sicyonis ingolfi. A - side view; B - top view; C - longitudinal section (arrow points to oral stoma); D - pedal disc.

Рис. 12. Sicyonis ingolfi. А — вид сбоку; В — вид сверху; С — вертикальный срез (стрелкой указана оральная стома); D - педальный диск.

The oral disc deeply invaginated (almost reached the middle of the column, Fig. 12C) with radial ridges along each exo- and endocoels and furrows along the lines of insertion of the mesenteries (Fig. 14C). The actinopharynx has two deep siphonoglyphs and about 16 longitudinal ridges on each side between the siphonoglyphs.

The preserved specimens are tan. Reddish-brown ectoderm is retained on the pedal disc and in wrinkles of the body, abraded on most parts of the column and tentacles. The ectoderm of the oral disc palebeige, ectoderm of the actinopharynx dark-brown; the filaments are dark-coloured; gonads yellowish. Coelenteron contains mud.

The marginal sphincter muscle is weak, very long (more than $3 \mathrm{~cm}$ ) and thin, occupies only a small part of the breadth of the mesogloea (about 1/10), wider in its distal end (up to $0.65 \mathrm{~mm}$ ) and gradually tapers proximally (Fig. 13B). It is chiefly mesogloeal and confined to the endodermal side of column, not separated from the circular endodermal muscles and forms with them endo-mesogloeal complex. The distal part of the sphincter is mostly reticular (Fig. 13C). In the proximal direction the reticular structure is retained on the endodermal side of the sphincter while the ectodermal side gradually becomes alveolar (Fig. 13D) and the whole long proximal part of the sphincter is alveolar (Fig. 13E). Circular endodermal musculature below the sphincter is very weak.

The mesogloea of the bases of the tentacles is thick, slightly thicker on the aboral side. Longitudi- 


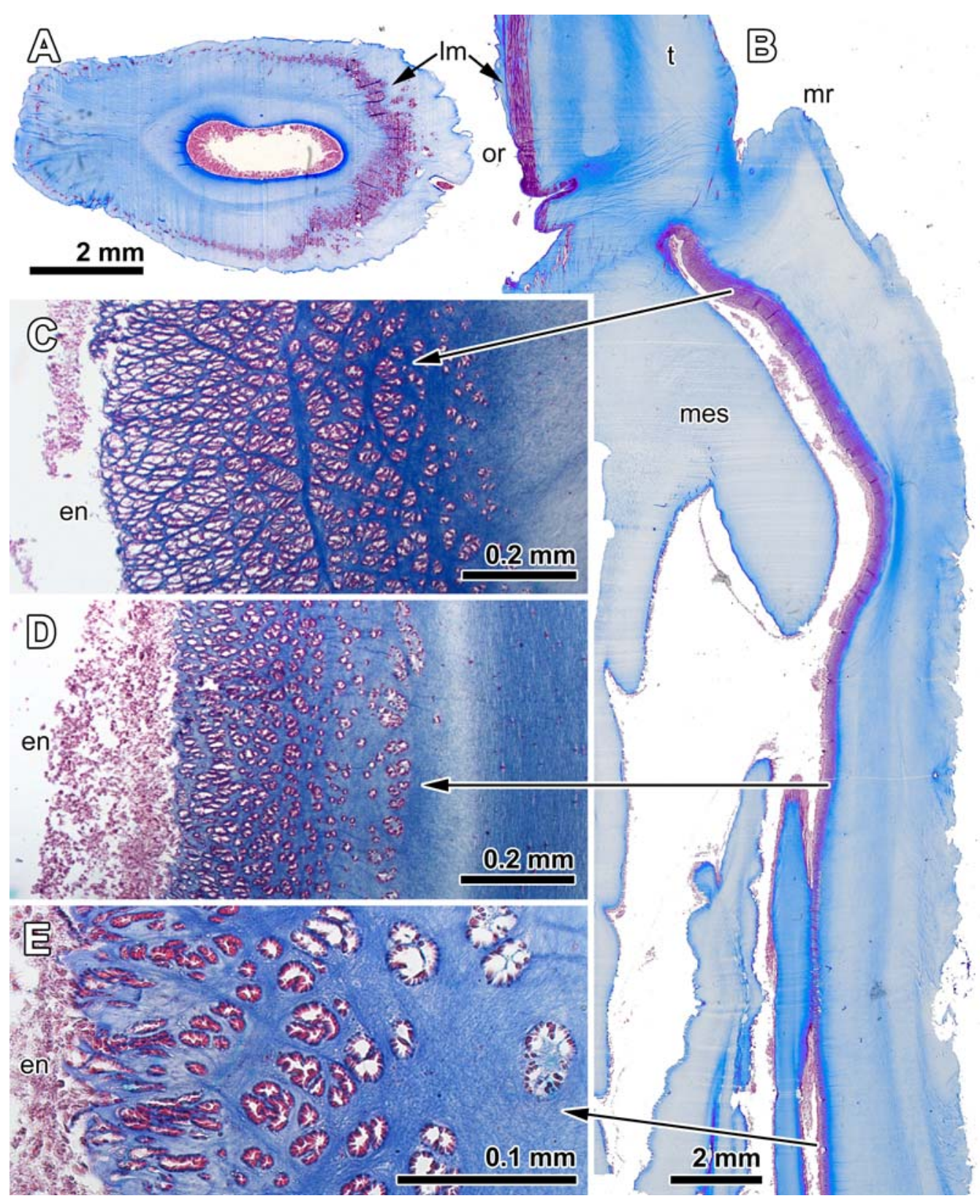

Fig. 13. Sicyonis ingolfi. A - transverse section of the tentacle; B - longitudinal section through the distal part of column; C - distal part of the sphincter; D - middle part of the sphincter; E - proximal part of the sphincter.

Abbreviations: en - endoderm; $1 \mathrm{~m}$ - longitudinal mesogloeal muscles of the tentacles; mes - mesentery; $\mathrm{mr}-$ marginal ridge; or - oral side of the tentacle; $\mathrm{t}$ - tentacle.

Рис. 13. Sicyonis ingolfi. А — поперечный срез через щупальце; В — продольный срез через верхнюю часть колюмна; C - дистальный участок сфинктера; D - средний участок сфинктера; Е проксимальный участок сфинктера.

Сокращения: en - энтодерма; $1 \mathrm{~m}$ - продольная мезоглеальная мускулатура щупалец; mes — мезентерий; $\mathrm{mr}$ маргинальный выступ; or - оральная сторона щупальца; $\mathrm{t}$ - щупальце. 


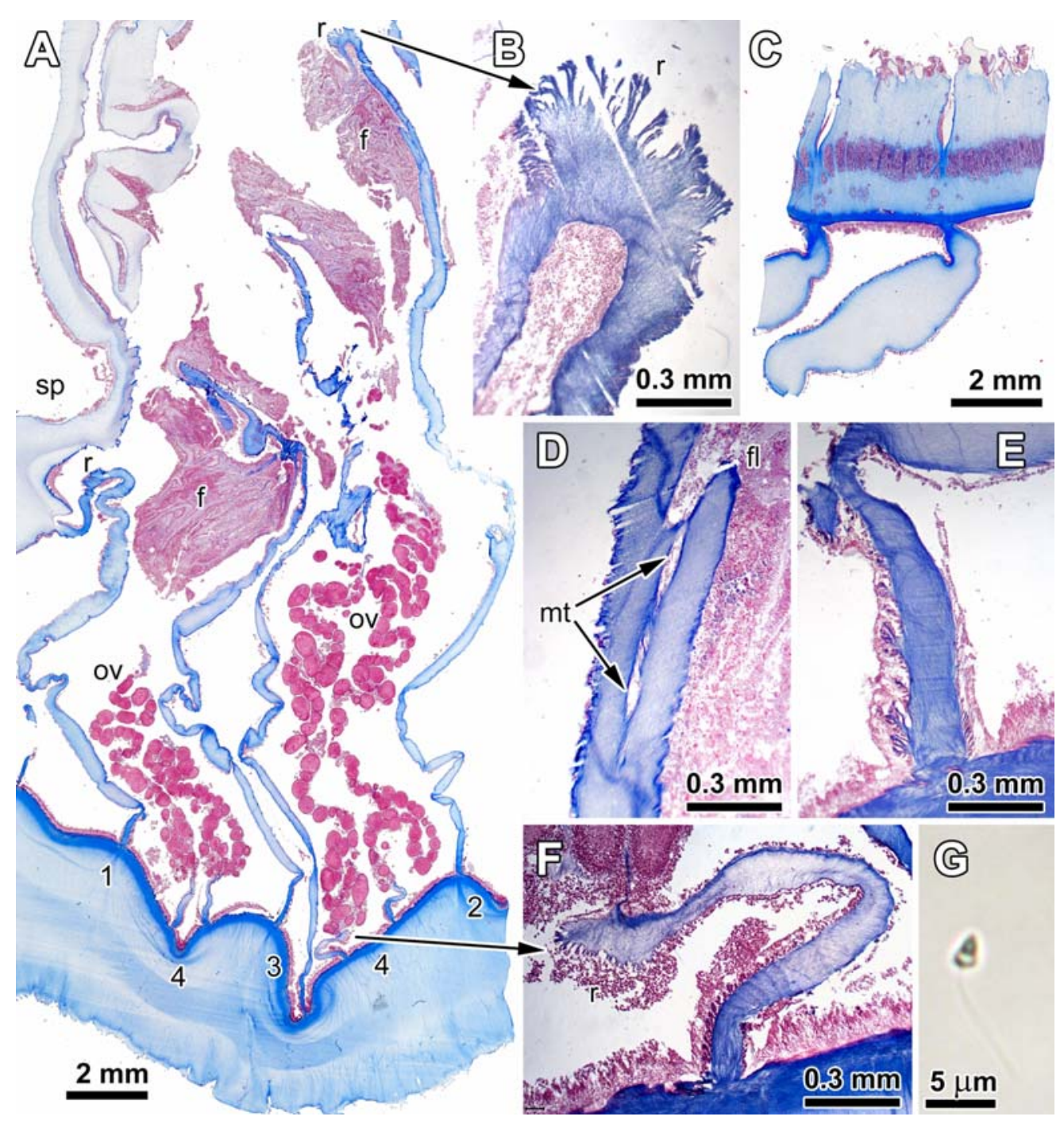

Fig. 14. Sicyonis ingolfi. A - transverse section of the column; B - retractor of the mesentery of the second cycle; $\mathrm{C}$ - transverse section of the oral disc; D - parieto-basilar part of the mesentery of the second cycle; $\mathrm{E}$ - parietal part of the directive; $\mathrm{F}$ - fertile mesentery of the fourth cycle; $\mathrm{G}$ - spermatozoon.

Abbreviations: $\mathrm{f}$ - filament; $\mathrm{fl}$ - parieto-basilar flap; $\mathrm{mt}$ - meshes of transverse muscles in the middle of the mesogloea of the mesentery; ov - ova; $\mathrm{r}$ - retractor; $\mathrm{sp}$ - siphonoglyph. Numbers indicate cycle number of mesenterial pairs. Рис. 14. Sicyonis ingolfi. А - поперечный срез через колюмн; В - ретрактор мезентерия второго цикла; $\mathrm{C}$ - поперечный срез через оральный диск; D - парието-базилярный участок мезентерия второго цикла; $\mathrm{E}$ - париетальная часть мезентерия первого цикла; $\mathrm{F}$ - фертильный мезентерий четвертого цикла; $\mathrm{G}$ - сперматозоид.

Сокращения: $\mathrm{f}$ - филаменты; $\mathrm{fl}$ - парието-базилярный выступ; $\mathrm{mt}$ - альвеолы с поперечной мускулатурой в толще мезоглеи мезентериев; ov — яйца; $\mathrm{r}$ - ретрактор; $\mathrm{sp}$ — сифоноглиф. Цифрами обозначены номера циклов мезентериальных пар.

nal muscles of the tentacles are mesogloeal, much stronger on the oral side of the tentacles where they are located in the middle of the mesogloea, and very weak on the aboral side of the tentacles, where they are represented by a chain of sparse meshes lying closer to the ectodermal side of the mesogloea (Fig. 13A). The radial muscles of the oral disc are mesogloeal, mostly reticular and strong, arranged into 


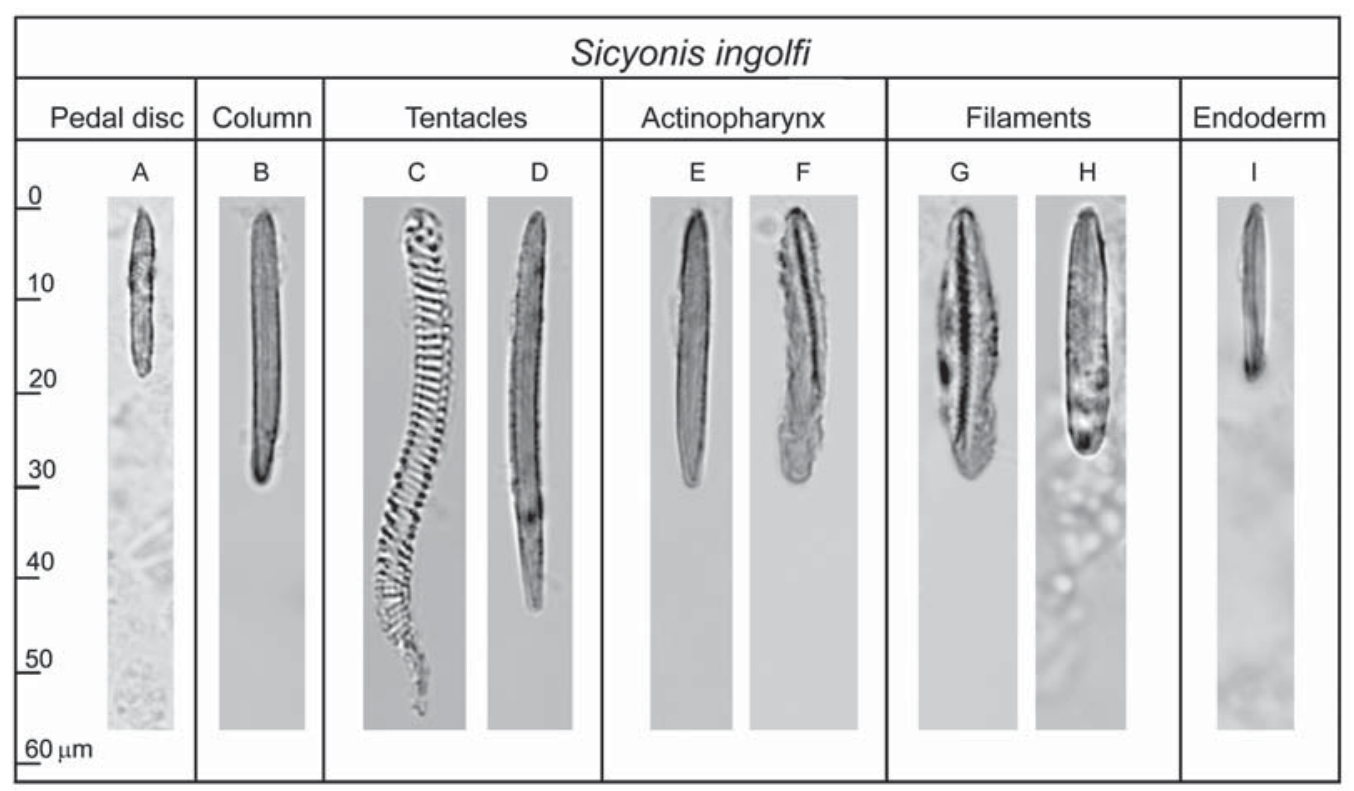

Fig. 15. Sicyonis ingolfi, distribution of cnidae (see Table 3 for size ranges).

Рис. 15. Sicyonis ingolfi, распределение книд (размеры указаны в табл. 3).

thick bundles running over each exo- and endocoel and separated by mesogloeal laminae along the lines of insertions of the mesenteries (Fig. 14C). They are not separated from longitudinal muscles of the oral sides of the tentacles.

The mesenteries are arranged into four cycles. The mesenteries of the first three cycles are sterile, have filaments and present along the whole length of the column. The mesenteries of last (the fourth) cycle are weak, fertile, lack filaments, present only in the proximal part of column. Actinostola-rule not discernible in the arrangement of the mesenteries. The first and the second cycles are composed of perfect mesenterial pairs. The third cycle is composed of imperfect pairs but also has unequal pairs in which one mesentery reaches the actinopharynx while the other not. In a half of the specimen from St. 50/373 the stronger (sterile) mesenteries are represented by three pairs of the first cycle (including a pair of directives), five pairs of the second cycle (with duplications in lateral and "ventral" primary exocoels) and alternating with them pairs of the third cycle, two of which are represented by unequal pairs (in lateral and "ventral" primary exocoels). The specimen from St. 73/386 has unequal number of mesenterial pairs on the sides of the directive plane: 20 pairs of sterile and 15 pairs of fertile mesenteries on the one side and 17 pairs of sterile and the same number of fertile mesenteries on another side (one of which had small trilobate filament), with duplications in the second and the third cycles.

All sterile mesenteries (three older cycles) have a very thick mesogloea in the distal part of the column. In the proximal part of the column all mesenteries are thin (Fig. 14A). Mesenterial musculature is very weak, developed in the same degree as the circular columnar muscles. Retractors are discernible only near the actinopharynx or filaments in sterile mesenteries (Fig. 14B) or near the gonads on fertile mesenteries (Fig. 14F). The parietobasilar muscles are also very weak but sometimes may form short flaps on the mesenteries of the first and the second cycles, from which a chain of muscle meshes (transverse mesenterial muscles) continues in the parietal direction to a distance of about $1 \mathrm{~mm}$ in the mesogloea (Fig. 14D). The parietal part of the musculature is better developed on the retractor muscle side of the mesenteries. It is composed here by short branched muscle processes up to $50 \mu \mathrm{m}$ long on the fertile and up to $70-80 \mu \mathrm{m}$ on sterile mesenteries. They extend on about $1 \mathrm{~mm}$ along the sterile mesenteries (Fig. 14E) and up to $700 \mu \mathrm{m}$ on fertile mesenteries (that is about a half of their length) (Fig. 14F). On the opposite (parieto-basilar) side parietal part of the musculature is much weaker, muscle processes are up to $20-30 \mu \mathrm{m}$ and extend along the mesentery on a distance of 200 $300 \mu \mathrm{m}$ (Fig. 14E). 
Large oral stomata on perfect mesenteries are up to $3 \times 1 \mathrm{~mm}$ (Fig. 12C), the marginal or central stomata were not detected. Ova and male follicles are up to $600 \mu \mathrm{m}$ in diameter. Spermatozoa with pointed tips, radially symmetric, $2-2.5 \times 1.5-2 \mu \mathrm{m}$ (Fig. $14 \mathrm{G}$ ).

Cnidom includes spirocysts, basitrichs, $p$-mastigophores A, p-mastigophores B1 (Tab. 3, Fig. 15). Columnar basitrichs (Fig. 15B) are smaller in the middle part of the column $(23-25 \mu \mathrm{m})$, than in its distal part $(27-34 \mu \mathrm{m})$ and on margin $(27-37 \mu \mathrm{m})$. The tentacles, the oral disc and the margin have the same set of cnidae - spirocysts and basitrichs, but spirocysts are significantly sparser in the ectoderm of the margin and the bases of the tentacles than in the tips of the tentacles and the oral disc. Spirocysts with unevenly coiled tubule sometimes occur on the margin and the oral disc, while in the tips of the tentacles all spirocysts have regularly coiled tubule. The cnidoglandular tracts of unilobate filaments contain $p$-mastigophores A and B1 (Fig. 15G, H) while the small basitrichs, similar to those from the endoderm (Fig. 15 I; 69 cnidae measured), which occur in the macerated samples of filaments, are present actually in the endoderm of the mesenteries near the cnidoglandular tracts, where they are more common than in the remaining endoderm. $P$-mastigophores $\mathrm{A}$ in the actinopharynx (10 cnidae measured) and filaments (Fig. 15F, G) have a thin-walled capsule of similar size without apical flap; undischarged shaft is $17-27 \mu \mathrm{m}$ and has $22-28$ turns of rows of spines. $P$-mastigophores B1 (Fig. $15 \mathrm{H}$ ) are present only in the filaments. They have thick-walled capsule with three-lobed apical flap; undischarged shaft is $12-16 \mu \mathrm{m}$ and has $10-14$ turns of rows of spines. Discharged shaft in the $p$-mastigophores A almost two times thicker $(2.5 \mu \mathrm{m})$ than in the $p$ mastigophores B1 $(1.2-1.5 \mu \mathrm{m})$. All basitrichs and $p$-mastigophores B1 (Fig. 15H) are stained by basic stains in contrast with $p$-mastigophores A and spirocysts.

HABITAT. The species lives on the soft bottom as it is evident from undamaged basal discs of collected specimens and the presence of mud in the gastral cavity.

REMARKS. Original description of Sicyonis ingolfi is based on one specimen collected south of Greenland $\left(58^{\circ} 20^{\prime} \mathrm{N}, 48^{\circ} 25^{\prime} \mathrm{W}\right)$, reported depth is 1685 fathoms ( $=3067 \mathrm{~m}$, but reported as $3192 \mathrm{~m}$ by Carlgren, 1928b for the same specimen). Two specimens described in the present work, both from northern part of Mid-Atlantic Ridge and from similar depths, were briefly mentioned (but not described) by Molodtsova et al. (2008) and are the only other known specimens of this species.
Simultaneously with $S$. ingolfi, Carlgren (1921) described two other species, S. tuberculata Carlgren, 1921 and S. variabilis Carlgren, 1921. In these species, in contrast with $S$. ingolfi, the tentacles occupy large part of the oral disc. Carlgren (1921: 217) especially stated that in $S$. ingolfi "the tentacles are closer than in S. tuberculata, therefore the tentacle-lacking part of the oral disc is large". Subsequently, many specimens identified as $S$. tuberculata were recorded in NW Atlantic in the abyssal plain (3680-4094 m) by Doumenc (1975) who considered S. tuberculata and S. ingolfi as probable synonyms but treated $S$. variabilis as a distinct species. Riemann-Zürneck (1991) stated that the specimens inhabiting abyssal plain and identified by Doumenc (1975) as $S$. tuberculata belong to a new species she described as $S$. biotrans (her description is based, however, on the specimens from NE Atlantic). She provided no detailed comparison with other nominal Sicyonis species, but, as is seems from her text, distinguished S. biotrans basing on the fact that it inhabits abyssal plain (rather than slope regions) and that "cnidae in the tentacle ectoderm at least $10 \mu \mathrm{m}$ larger than in any other related species" (spirocysts up to $81 \mu \mathrm{m}$ and large basitrichs $42-60 \mu \mathrm{m}$ ). However, the specimens reported by Doumenc (1975) have much smaller cnidae in the tentacles (spirocysts 20-60 $\mu \mathrm{m}$ and larger basitrichs $34-38 \mu \mathrm{m}$ ) and the tentacles occupy most part of the oral disc, while in $S$. biotrans they are arranged in two cycles on the margin of the very wide oral disc. The specimens reported by Doumenc (1975) (at least those of them on which he based his description) cannot be conspecific with $S$. biotrans and appear to be correctly identified as $S$. tuberculata. Thus, S. biotrans is not the only species of Sicyonis inhabiting abyssal plains and this feature alone (a habitat) cannot be used to distinguish it. In the arrangement of the tentacles on the periphery of the large oral disc S. biotrans resembles $S$. ingolfi. However, the type specimen of S. ingolfi (see Carlgren, 1921) and the specimens of this species reported in the present work indeed have somewhat smaller tentacular basitrichs and spirocysts than those reported for S. biotrans by RiemannZürneck (1991) and in the present paper we treat them as distinct species.

\section{Sicyonis titanic sp.n.} Table 4; Figs 16-19A, 20.

MATERIAL EXAMINED. Holotype ZMMU Ec-120. RV Akademik Mstislav Keldysh, 49 cruise, St. 4569, 6-7 July 2003, North Atlantic, polygon Titanic, $41^{\circ} 38.304^{\prime} \mathrm{N}, 49^{\circ} 37.26^{\prime} \mathrm{W}, 3182-3153 \mathrm{~m}$, Sigsbee trawl, one specimen. 
Table 4. Size ranges (length $\times$ width, in microns) and distribution of cnidae of Sicyonis titanic sp.n. Letters in brackets correspond to letters in Fig. 20.

Таблица 4. Размеры (длина $×$ ширина, в микронах) и распределение стрекательных капсул Sicyonis titanic sp.n. Буквы в скобках соответствуют буквам на рис. 20.

\begin{tabular}{lll}
\hline Body region & Cnidae & Size ranges $(\mu \mathrm{m})$ \\
\hline Pedal disc & (A) basitrichs (common) & $19-29 \times 2.5-3.5$ \\
\hline Column & (B) basitrichs (common) & $24-36 \times 2.5-4$ \\
\hline \multirow{2}{*}{ Tentacles } & (C) spirocysts (numerous) & $28-87 \times 3-6.5$ \\
& (D) basitrichs (common) & $26-54 \times 2.5-4$ \\
\hline \multirow{2}{*}{ Actinopharynx } & (E) basitrichs (common) & $32-50 \times 2.5-4$ \\
& (F) p-mastigophores A (few) & $23-37 \times 3.5-6$ \\
\hline \multirow{2}{*}{ Filaments } & (G) basitrichs (common) & $32-54 \times 2.5-4$ \\
& (H) p-mastigophores A (common) & $18-46 \times 3.5-9$ \\
& (I) p-mastigophores B1 (common) & $26-39 \times 4-7$ \\
\hline Endoderm & (J) p-mastigophores B1 (very rare) & $44-50 \times 3-3.8$ \\
\hline
\end{tabular}

DESCRIPTION. Preserved specimen is large, 9 $\mathrm{cm}$ in diameter and height (Fig. 16A). Freshly collected specimen was rose colored. The pedal disc is circular, deeply concave, forms a cavity with an opening about $4 \mathrm{~cm}$ in diameter. The cavity contains sheets of cuticle-like material and sand. The pedal disc is not damaged (Fig. 16B, C). The column is cylindrical, smooth, with very shallow circumferential narrowing in the middle (Fig. 16B). The distal part of the column, with the tentacles, is turned inward. It has longitudinal ridges continuing to the bases of the tentacles, they are probably artefacts of contraction. The column is light-beige; its ectoderm is almost totally abraded. The mesogloea is very thick, up to $1 \mathrm{~cm}$ in the distal part of the column and about $4 \mathrm{~mm}$ in its middle part but becomes thinner near the limbus and thin in the pedal disc.

About 100 tentacles are arranged in two cycles on the margin of the oral disc. They are triangular, with aboral thickening at the base. The oral disc has zones with large tentacles (to $2 \mathrm{~cm}$ in length and 1.5 in width at the bases) and with very small, even rudimentary, tentacles. This may be a result of trauma and regeneration because three sections of small tentacles alternate with three sections of large tentacles unevenly.

The oral disc deeply invaginated (almost to a middle of the column height). It has radial ridges along each exo- and endocoels with darker ectoderm and lighter radial furrows along the mesenterial insertions (Fig. 16B). The actinopharynx has two deep siphonoglyphs and about 20 longitudinal ridges between them on each side corresponding to the insertions of the mesenteries (Fig. 16D). The ectoderm of the distal (upper) part of the actinopharynx is yellowish-beige, but brown in its proximal part.

The marginal sphincter muscle is mesogloeal, located along the endodermal side and not separated from the circular columnar muscles. The sphincter is weak and thin in comparison with the body size and occupies only a small part of the breadth of the mesogloea (about 1/10), wider in its distal end (up to $1 \mathrm{~mm}$ ) and gradually tapers proximally, about $4.5 \mathrm{~cm}$ in length (Fig. 17B). In the distal part the sphincter is mostly reticular (Fig. 17E), gradually becomes alveolar in the proximal direction, especially on its endodermal side (Fig. 17C, D). The sphincter is alveolar in its proximal part (Fig. 17A). Circular endodermal muscles below the sphincter are very weak, with short, not branched processes up to 30 $\mu \mathrm{m}$ in length. Similar endodermal muscles are on the oral disc.

Longitudinal muscles of the tentacles mesogloeal, better developed on the oral side where mesogloea is thinner, and very weak on the aboral side where the mesogloea is thick, situated close to the ectoderm (Fig. 17F). The radial muscles of the oral disc are mesogloeal, running over each exo- and endocoel in the middle of the mesogloea (Fig. 18B).

The mesenteries are arranged into five cycles: $6+6+13+28+53=106$ pairs. The mesenteries of the first four cycles are sterile, have filaments and present along the whole length of the column. The mesenteries of the last (the fifth) cycle are weak, fertile, lack filaments (except one mesentery with small trilobate filament only, Fig. 19A), present only in the proxi- 


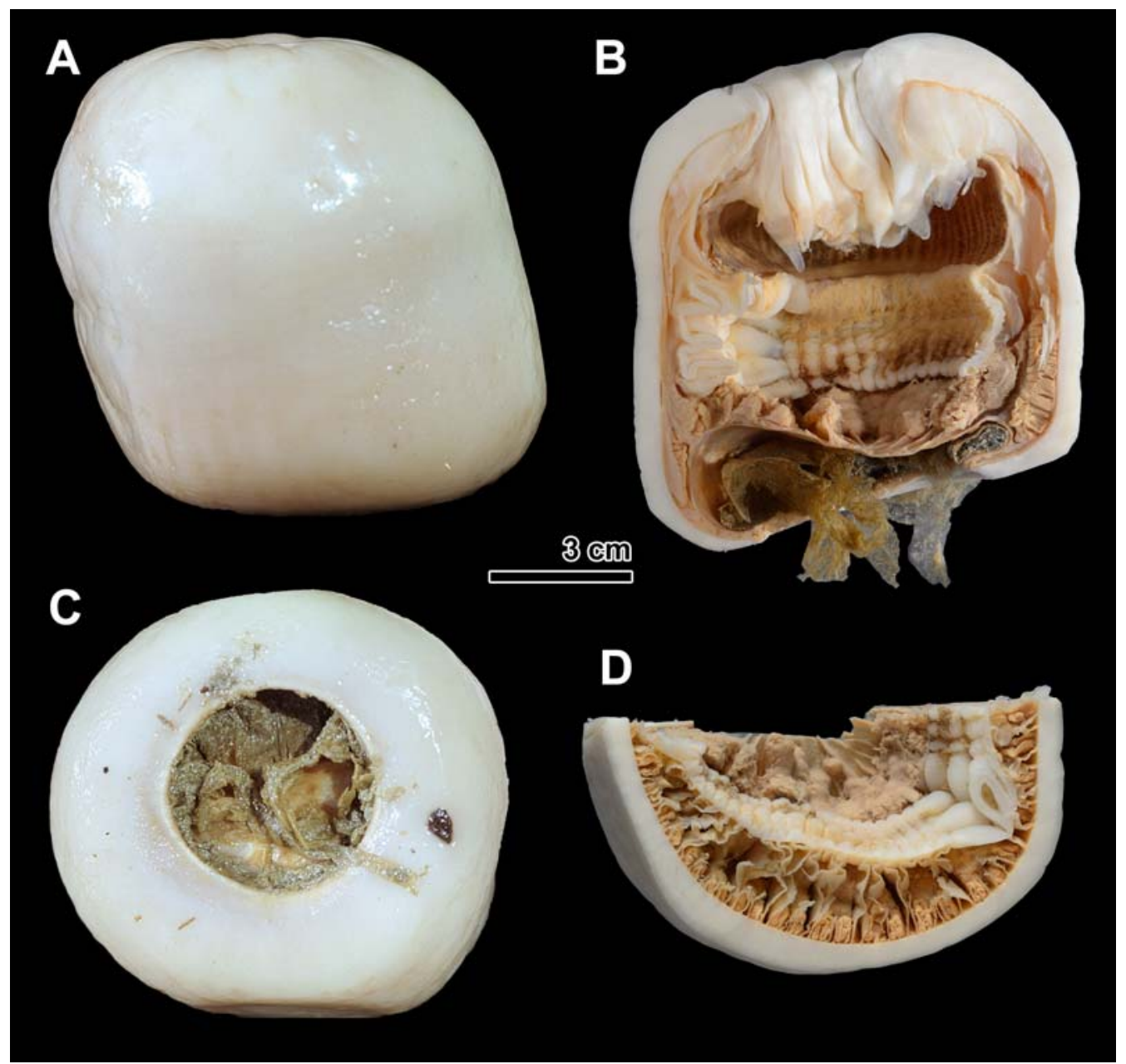

Fig. 16. Sicyonis titanic sp.n. A — side view; B — longitudinal section; C - pedal disc; D - transverse section of the half of column.

Рис. 16. Sicyonis titanic sp.n. А — вид сбоку; В — вертикальный срез; C - педальный диск; D поперечный срез через половину колюмна.

mal part of the column. Actinostola-rule not discernible in the arrangement of the mesenteries (Fig. 18A). The first, second and third cycles are represented by perfect pairs with the exception of one additional unequal pair, probably belonging to a third cycle, thus there are 24 perfect pairs + one perfect mesentery of unequal pair. All mesenteries of the fourth cycle are imperfect. The fourth cycle has three duplicated pairs (Fig. 19A).

All sterile mesenteries (four cycles) have thickened mesogloea in the distal part of column (Fig. 17B). Retractor muscles of all mesenteries are diffuse (Fig. 18A). The parietobasilar muscles are weak, may form short flaps (up to $180 \mu \mathrm{m}$ ) on perfect mesenter- ies. A chain of muscle meshes continues in the mesogloea of the mesentery from the flap to the body wall. These meshes are located closer to the retractor side of the mesentery (Fig. 18D). On imperfect sterile mesenteries (penultimate cycle) the parieto-basilar flap usually not formed, but a chain of the meshes of transverse muscles in the mesogloea in the parieto-basilar section of the mesentery is always developed and situated closer to the retractor side of the mesentery (Fig. 18E). The parietal part of the musculature well developed on the retractor-side of the mesentery, where it is represented by branched muscle processes up to $275 \mu \mathrm{m}$ in length. On the opposite (parieto-basilar) side of the mesentery the parietal part of the musculature is 


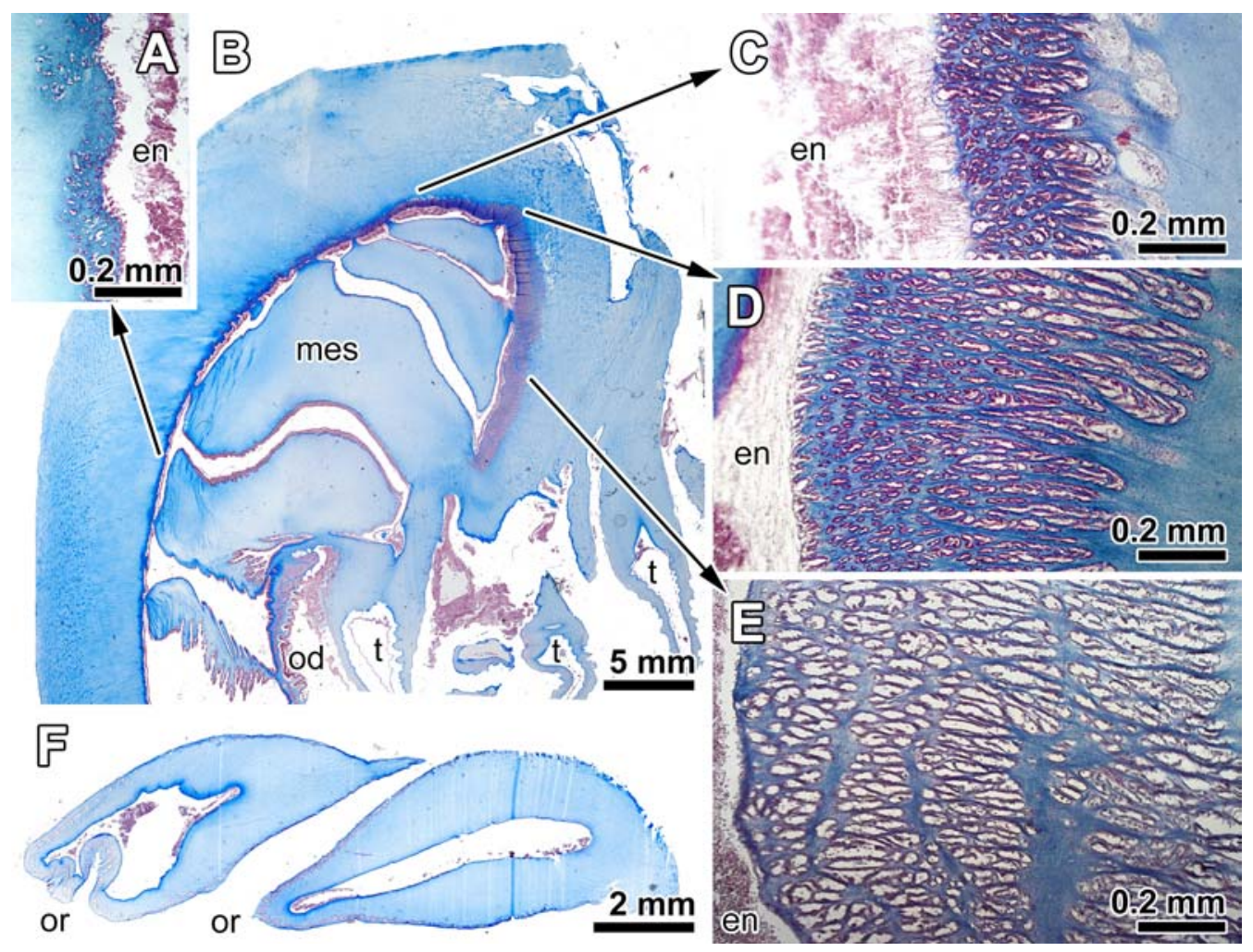

Fig. 17. Sicyonis titanic sp.n. A - proximal part of the sphincter; B - longitudinal section through the distal part of column; C, D - middle part of the sphincter; E - distal part of the sphincter; F — transverse section of the tentacles.

Abbreviations: en — endoderm; mes - mesentery; od — oral disc; or — oral side of the tentacle; $\mathrm{t}$ - tentacle.

Рис. 17. Sicyonis titanic sp.n. А - проксимальный участок сфинктера; В - продольный срез через верхнюю часть колюмна; C, D - средний участок сфинктера; E - дистальный участок сфинктера; F - поперечный срез через щупальца.

Сокращения: en — энтодерма; mes — мезентерий; od — оральный диск; or — оральная сторона щупальца; $\mathrm{t}$ щупальце.

poorly developed, muscle processes here are up to 60 $\mu \mathrm{m}$ (Fig. 18F). Fertile mesenteries are short, their muscular part is about $500 \mu \mathrm{m}$ in length, muscle processes on their retractor-side (up to $185 \mu \mathrm{m}$ ) and on parieto-basilar side (up to $55 \mu \mathrm{m}$ ) are similar to those of the parietal part of the musculature of other mesenteries (Fig. 18G).

Mesenterial stomata are very small in relation to the size of the body: oral stomata are up to $1 \mathrm{~mm}$, central stomata $0.5 \mathrm{~mm}$, the latter are in the middle of the height of column. Fertile mesenteries (the last cycle) have well-developed male follicles up to 350 $500 \mu \mathrm{m}$ in diameter. Spermatozoa have pointed tips, radially symmetric, 3-4 × 1.5-2 $\mu \mathrm{m}$ (Fig. 18C).

Cnidom includes spirocysts, basitrichs, $p$-mastigophores A and $p$-mastigophores B1 of two different types (Tab. 4, Fig. 20). The ectoderm of the tentacles and the oral disc contain spirocysts and basitrichs, in the oral disc the basitrichs are slightly smaller (19$46 \times 2.5-4 \mu \mathrm{m})$ and some spirocysts resemble robust type: the spirocysts with unevenly coiled tubule are slightly wider $(43-65 \times 4.7-6.5 \mu \mathrm{m})$, than the spirocysts with evenly coiled tubule $(33-70 \times 3-5.5 \mu \mathrm{m})$. Also, some spirocysts are intermediate between these two types $(38-54 \times 4.2-5.4 \mu \mathrm{m})$. In the tentacles almost all spirocysts are of gracile type. The cnidoglandular tracts of unilobate filaments contain large basitrichs (Fig. 20G), $p$-mastigophores A (Fig. $20 \mathrm{H}$ ) and two types of $p$-mastigophores B1 (both thick-walled and with three-lobed apical flap). One type of $p$-mastigophores B1 (Fig. $20 \mathrm{I}$ ) has wider capsule, thin and usually slightly curved shaft with indistinct $\mathrm{V}$ in the end; undischarged shaft is less than a half of the length of the capsule $(10-20 \mu \mathrm{m})$ 

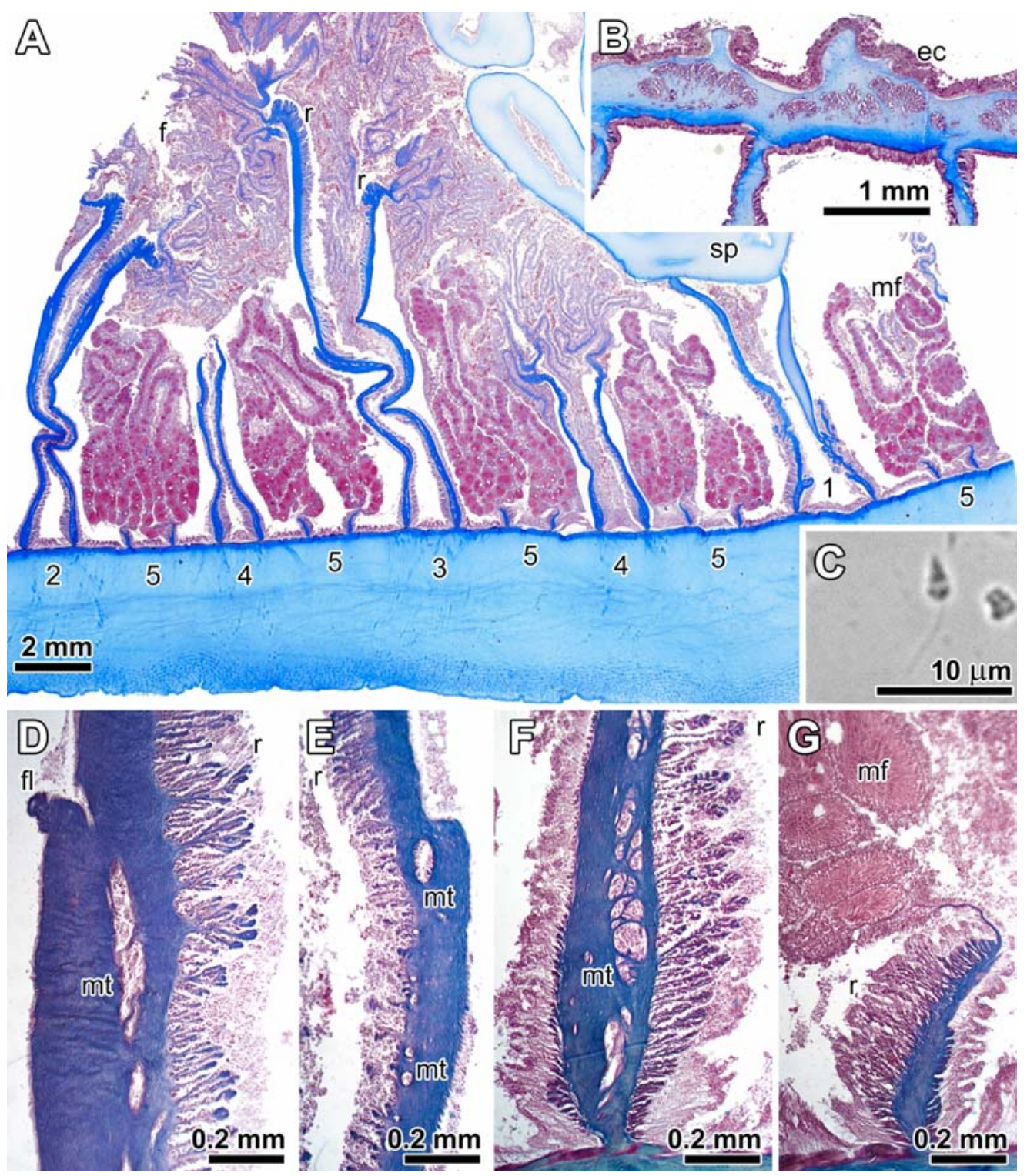

Fig. 18. Sicyonis titanic sp.n. A - transverse section of the column; B - transverse section of the oral disc; $\mathrm{C}$ - spermatozoon; D - parieto-basilar part of the mesentery of the second cycle; E - parieto-basilar part of the mesentery of the fourth cycle; F - parietal part of the sterile mesentery of the second cycle; $G$ - a part of the mesentery of the second cycle with parieto-basilar muscles.

Abbreviations: ec - ectoderm; f - filament; $\mathrm{fl}$ - parieto-basilar flap; $\mathrm{mf}$ - male follicles; $\mathrm{mt}$ - meshes of transverse muscles in the middle of the mesogloea of the mesentery; $\mathrm{r}$ - retractor; $\mathrm{sp}$ - siphonoglyph. Numbers indicate cycle number of mesenterial pairs.

Рис. 18. Sicyonis titanic sp.n. A - поперечный срез через колюмн; В - поперечный срез через оральный диск; $\mathrm{C}$ - сперматозоид; D - парието-базилярный участок мезентерия второго цикла; $\mathrm{E}-$ парието-базилярный участок мезентерия четвертого цикла; $\mathrm{F}$ - париетальная часть стерильного мезентерия второго цикла; $\mathrm{G}$ - участок париетобазилярных мускулов мезентерия второго цикла. Сокращения: ес - эктодерма; $\mathrm{f}$ - филаменты; $\mathrm{fl}$ - парието-базилярный выступ; $\mathrm{mf}$ - семенники; $\mathrm{mt}-$ альвеолы с поперечной мускулатурой в толще мезоглеи мезентериев; $\mathrm{r}$ - ретрактор; $\mathrm{sp}$ - сифоноглиф. Цифрами обозначены номера циклов мезентериальных пар. 

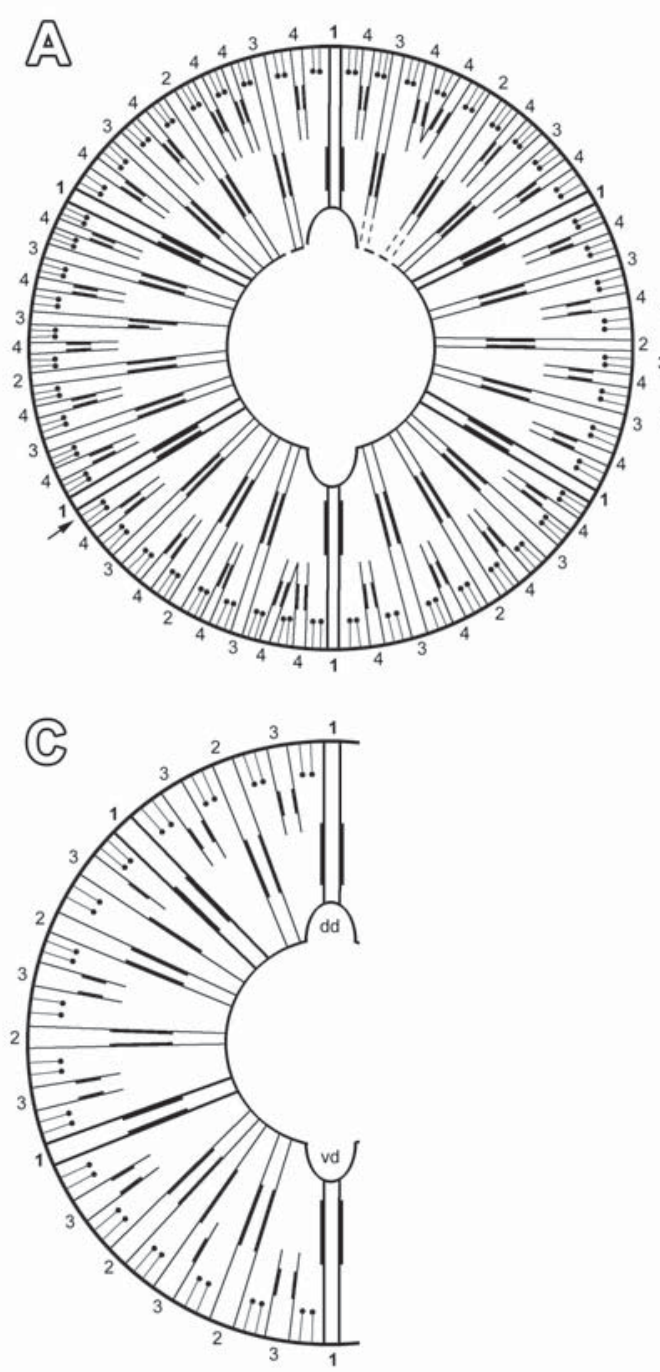

and discharged shaft is shorter than a capsule (19-29 $\times 1-1.7 \mu \mathrm{m})$; the shaft has $15-21$ spiral turns of rows of spines; the capsule not stained by basic dyes. Another type of $p$-mastigophores B1 (Fig. 20J) is very rare (only four capsules were found) has narrow long capsule and is stained by basic stains. Small basitrichs, of the same type as in the endoderm (Fig. $20 \mathrm{~K}$; 37 cnidae measured), which occur on the macerated samples of filaments, are present actually in the endoderm of the mesenteries near the cnidoglandular tracts. Thin-walled $p$-mastigophores A of the actinopharynx and filaments have no apical flaps and not stained by basic dyes. In the filaments their size ranges are wider (Fig. 20H) and they show

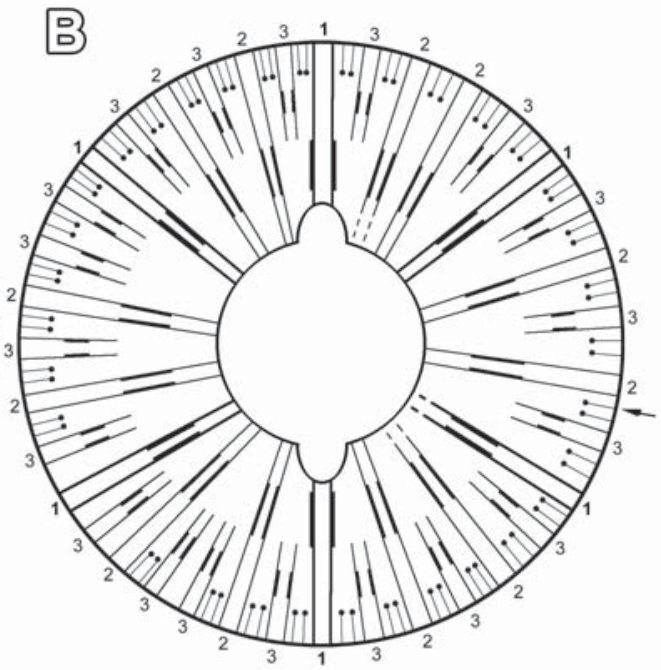

Fig. 19. Arrangement of the mesenteries. A Sicyonis titanic sp.n.; B, C - Sicyonis ingolfi: B specimen St. 73/386, female; C - specimen St. 50/ 373, male.

Numbers indicate cycle number of sterile mesenterial pairs. Gonads are marked by small black circles on the end of the mesenteries of the last cycle. Arrow indicate a mesentery of the last fertile cycle bearing trilobate filament. Abbreviations: dd — "dorsal" directives; vd — "ventral" directives. Numbers indicate cycle number of mesenterial pairs.

Рис. 19. Организация мезентериев. А - Sicyonis titanic sp.n.; B, C — Sicyonis ingolfi: B - экземпляр St. 73/386, самка; C — экземпляр St. 50/373, самец.

Цифрами обозначены номера циклов стерильных мезентериальных пар. Гонады обозначены черными кружочками на концах мезентериев последнего цикла. Стрелкой указан мезентерий последнего, фертильного, цикла с трилобатным филаментом. Сокращения: dd - “дорсальные" направляющие пары мезентериев; $\mathrm{vd}$ - “вентральные” направляющие пары мезентериев.

greater variability in the ratio of the length and the width of the capsule, in the size of the shaft (undischarged 11-27 $\mu \mathrm{m}$, discharged 22-32 × 1.7-2.2 $\mu \mathrm{m}$ ) and number of spiral turns of rows of spines (12-30) while undischarged shaft of $p$-mastigophores $\mathrm{A}$ in the actinopharynx (Fig. 20F) is $15-22 \mu \mathrm{m}$ and has 20-21 spiral turns of rows of spines. All basitrichs are stained by basic stains.

HABITAT. Most probably this species lives unattached on the soft bottom - the pedal disc was undamaged in collected specimen and basal cavity contained mud and sand.

ETYMOLOGY. The species is named in memory of more than 1500 sailors and passengers who 


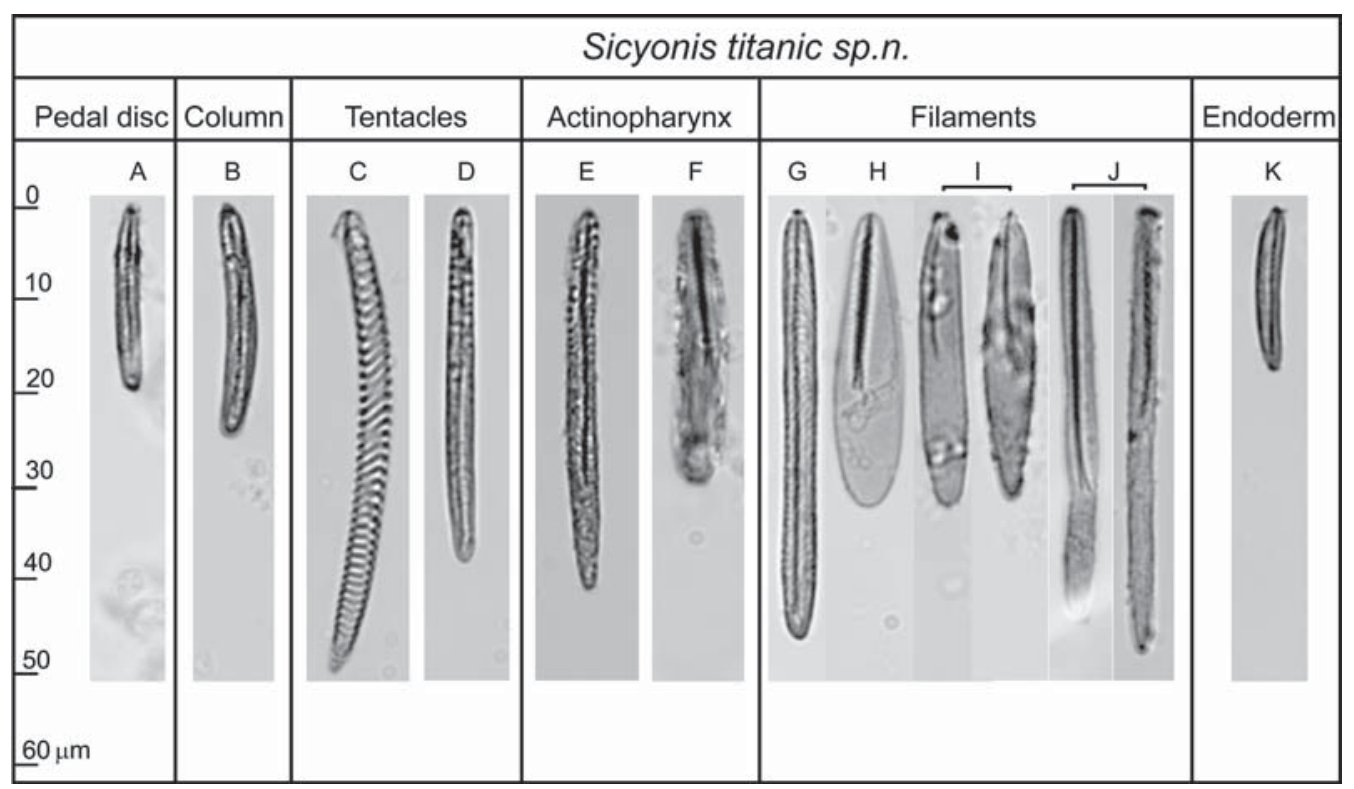

Fig. 20. Sicyonis titanic sp.n., distribution of cnidae (see Table 4 for size ranges).

Рис. 20. Sicyonis titanic sp.n., распределение книд (размеры указаны в табл. 4).

died in the crash of HMS Titanic that sank on April 1912 in this area.

REMARKS. Sicyonis titanic sp.n. belongs to a group of several species which live unattached on soft bottom (and hence very characteristic appearance of the aboral side, see Fig. 16C and also Riemann-Zürneck, 1991, P1. 1) and have the tentacles arranged in two cycles on the margin of wide oral disc. In North Atlantic this group certainly includes S. biotrans, S. ingolfi, S. gossei and, possibly, $S$. obesa and $S$. haemisphaerica. It may be assumed that in live Sicyonis titanic sp.n. looks like S. biotrans as shown on the underwater photographs published by Riemann-Zürneck (1991, Pl. 2). The present species differs from $S$. biotrans by more numerous tentacles. Riemann-Zürneck, 1991: 9 reported " 60 to about 80 " tentacles in S. biotrans and especially noted that "even in the largest animals the number of tentacles does not attain the full (hexamerous) set of 96 tentacles".

Cnidom of $S$. titanic sp.n. and $S$. biotrans also differs significantly. Tentacular basitrichs and spirocysts in S. titanic sp.n. are smaller than in S. biotrans. Riemann-Zürneck (1991) treated large size of these cnida as a character distinguishing her species from all other North Atlantic species of Sicyonis. Moreover, Sicyonis titanic sp.n., has two types of very peculiar $p$-mastigophores $\mathrm{B} 1$ in the filaments (Fig. 20 I, J). They not present in North Atlantic species $S$. biotrans and $S$. ingolfi, for which detailed cnidom is reported. Details of the cnidom not known for $S$. gossei, S. obesa and S. haemisphaerica.

Sicyonis gossei is described from East Atlantic. The single known specimen is $6.5 \times 5.5 \mathrm{~cm}$, about two times smaller than the present species, but has more numerous tentacles (151) and much stronger sphincter. On published figure (Stephenson, 1918, Pl. 14, Fig. 10) it occupies about one third of the width of the mesogloea and, possibly, more closely resembles the sphincter of $S$. kuznetsovi sp.n. (see Fig. 8B) rather than that of S. titanic sp.n. In S. titanic sp.n. the sphincter is much thinner ( $1 / 10$ of the width of the mesogloea). Riemann-Zürneck (1991) tried to loan the type specimen of $S$. gossei to study its nematocysts but it has not been found.

Original description of Sicyonis obesa, published by Carlgren (1934), is based on one specimen from Chesapeake Bay, 1239 fathoms $(=2255 \mathrm{~m})$, labelled (but not published) by Verrill as Actinernus obesus. This specimen has about the same size as the present species $(11.5 \times 10.5 \mathrm{~cm})$ but has significantly less numerous tentacles (67) and mesenteries (34 pairs distally). No other specimens of this species are known.

Sicyonis haemisphaerica is known from the type specimen only collected in East Atlantic. According to original description (Carlgren, 1934) it has about 70 tentacles and its sphincter occupies a half of the width of the mesogloea and is much stronger than in the present species (see Carlgren, 1934, Fig. 2). 
The remaining two North Atlantic species, $S$. tuberculata and $S$. variabilis have the tentacles arranged in more than two cycles and, in contrast with the present species, occupy a significant part of the oral disc.

\section{Genus Ophiodiscus Hertwig, 1882}

Type species: Ophiodiscus annulatus Hertwig, 1882, by subsequent designation (see Carlgren, 1921: 186).

Ophiodiscus closely resembles Sicyonis, in both genera gonads are developed (usually profusely) on the youngest cycle of the mesenteries which lack filaments and present only in proximal part of the body. In Ophiodiscus, in contrast with Sicyonis, the tentacles are arranged in a single circle on the margin and not differentiated histologically from the oral disc and distal part of the column.

Carlgren (1921: 186) thought that Ophiodiscus may be "identical with Sicyonis or at least nearly allied to it" but preferred to treat it as valid. In his key to genera Carlgren (1949) placed Ophiodiscus and Sicyonis in two different sections: Ophiodiscus was placed together with Actinostola, Paractinostola Carlgren, 1928 and Stomphia in the section entitled "Mesenteries distinctly arranged according to Actinostola-rule", while Sicyonis, Parasicyonis Carlgren, 1921 and Synsicyonis are in the section "Mesenteries indistinctly arranged according to Actinostola-rule". This distinction is not reliable, in all species of Sicyonis and Ophiodiscus we were able to examine the mesenteries are not arranged according to Actinostola-rule (see comments under family Sicyonidae).

Another feature separating Ophiodiscus from Sicyonis mentioned by Carlgren $(1921,1949)$ is that the tentacles of Ophiodiscus are arranged in a single circle and that they are very long. Actually, it is not known whether the tentacles in type species of Ophiodiscus are very long (they are severely damaged in type material), but in described here Ophiodiscus bukini sp.n. they are of ordinary length, comparable with the tentacles of many Sicyonis species. However, their arrangement in a single circle appear be a significant feature separating Ophiodiscus from $\mathrm{Si}$ cyonis. Further, in Ophiodiscus the tentacles are not differentiated histologically from the column and the oral disc. This is clearly demonstrated in $O$. bukini sp.n. (see Fig. 28B): the whole outer (aboral) side of the tentacle, from its base to the tip, has the mesogloea of the same thickness as in distal part of the column and has the same nematocysts, and the whole oral side of the tentacle not distinguishable histologically from the oral disc neither by thickness of its layers, not by appearance of its musculature or by composition of cnidae and their abundance.

In addition, it is worth to mention possible differences in the mesenterial stomata. The mesenteries in Sicyonis species, in which this feature is reported, usually (although not always) have two stomata: the oral and the central. (The central stoma is actually the marginal stoma shifted toward the middle of the mesentery, a tendency characteristic for Sicyonis and Exocoelactis). In Ophiodiscus we were able to detect only the oral stoma in $O$. bukini sp.n. while in $O$. moskalevi stomata not present. The value of this difference does not appear to be high, and there are some exceptions (e.g. described above $S$. ingolfi also has only oral stomata), but it will be worth to pay attention on this feature in future.

The genus Ophiodiscus was erected by Hertwig (1882) for two species collected by Challenger Expedition in SE Pacific (off Chile) in about the same location: O. annulatus Hertwig (1882) $\left(33^{\circ} 31^{\prime} \mathrm{S}\right.$, $74^{\circ} 43^{\prime} \mathrm{W}$, four specimens, 2160 fathoms $=3931 \mathrm{~m}$ ) and $O$. sulcatus Hertwig (1882) $\left(33^{\circ} 42^{\prime} \mathrm{S}, 78^{\circ} 18^{\prime} \mathrm{W}\right.$, one specimen, 1375 fathoms $=2502 \mathrm{~m}$ ). Ophiodiscus annulatus is a type species of the genus by subsequent designation (Carlgren, 1921: 186), not by monotypy as stated by Fautin (2016). No other specimens assignable to Ophiodiscus were recorded again till now, two new species of Ophiodiscus described in the present work are the first specimens of Ophiodiscus reported since Hertwig's (1882) publication.

\section{Ophiodiscus moskalevi sp.n. \\ Table 5; Figs 21-25A, 26.}

MATERIAL EXAMINED. Holotype ZMMU Ec-119. RV Akademik Mstislav Keldysh, 22 cruise, St. 2323, 10 August 1990, NW Pacific, east off Kamchatka, $53^{\circ} 05.4^{\prime} \mathrm{N}, 161^{\circ} 55.2^{\prime} \mathrm{E}-53^{\circ} 07^{\prime} \mathrm{N}, 161^{\circ}$ $56.12^{\prime} \mathrm{E}, 4890-4984 \mathrm{~m}$, Sigsbee trawl, one specimen.

DESCRIPTION. The single available specimen is about $4.5 \mathrm{~cm}$ in diameter and $2 \mathrm{~cm}$ high. The column is in a form of short cylinder and has a circumferential furrow in the middle (Fig. 22A). The pedal disc is circular, slightly concave, with visible mesenterial insertions, the ectoderm is retained on some its parts, without the remnants of the cuticle. Oral disc is flat, on the one side is bent in such a way that the tentacles are above the mouth, another side extended horizontally, a state which possibly reflects its position on the substrate in live (Fig. 21A, B). The diameter of the oral disc was probably significantly larger in expanded live specimen. The 
Table 5. Size ranges (length $\times$ width, in microns) and distribution of cnidae of Ophiodiscus moskalevi sp.n. Letters in brackets correspond to letters in Fig. 26. Таблица 5. Размеры (длина $\times$ ширина, в микронах) и распределение стрекательных капсул Ophiodiscus moskalevi sp.n. Буквы в скобках соответствуют буквам на рис. 26.

\begin{tabular}{lll}
\hline Body region & Cnidae & Size ranges $(\mu \mathrm{m})$ \\
\hline Pedal disc & (A) basitrichs (numerous) & $18-24 \times 2-2.5$ \\
\hline Column & (B) basitrichs (common) & $19-27 \times 2-2.5$ \\
\hline \multirow{2}{*}{ Tentacles } & (C) spirocysts (numerous) & $27-60 \times 2.5-5.5$ \\
& (D) basitrichs (common) & $26-39 \times 2-3$ \\
\hline \multirow{2}{*}{ Actinopharynx } & (E) basitrichs (common) & $18-30 \times 2-2.5$ \\
& (F) p-mastigophores A (common) & $25-40 \times 3.5-6$ \\
\hline \multirow{2}{*}{ Filaments } & (G) p-mastigophores A (common) & $28-39 \times 5-6$ \\
& (H) p-mastigophores B1 (numerous) & $29-39 \times 3.5-5$ \\
\hline Endoderm & (I) basitrichs (see text) & $16-23 \times 2-3$ \\
\hline
\end{tabular}

actinopharynx has two very large thick-walled siphonoglyphs, supported by two pairs of directives and ten ridges on each side between the siphonoglyphs which correspond to the insertions of perfect mesenteries (Fig. 23B).

The tentacles, 48 in number, are arranged in a single circle on a margin where they stand side by side. Distal parts of the tentacles are damaged and it is hard to estimate the true length, but they are not short and probably all of similar length (Fig. 21B). The tentacles have rather thick mesogloea at the base; its thickness is the same on the oral and aboral sides (no aboral thickening; Fig. 23F).

The ectoderm is abraded and the external layers of the mesogloea are severely damaged, the layers of the mesogloea are in shreds and detached in some parts (Fig. 21A-C). The mesogloea is better retained in the middle part of the column, where its thickness is $2 \mathrm{~mm}$, and in the pedal disc (up to $1.5 \mathrm{~mm}$ thick). The preserved specimen is light brownish due to the colour of the internal structures (endoderm, mesenteries, gonads and muscles) visible through colourless semitransparent layers of the remaining mesogloea.

The marginal sphincter muscle is strong, mostly reticular, composed by numerous crowded and relatively large meshes (Fig. 22B) forming a wide band occupying about half of the mesogloea thickness in the distal third of the column. The sphincter is confined to the endodermal side of the mesogloea, where it forms very characteristic folds (Fig. 22A) visible on the intact specimen as a series of strong circular muscle bands encircling the distal part of the column (Fig. 21A, C). The structure of the sphincter is homogenous (not stratified) (Fig. 22C, D). The sphincter forms an endo-mesogloeal complex with circular endodermal columnar muscles. Its thickness in distal part is up to $450 \mu \mathrm{m}$. Proximally the sphincter gradually becomes narrower and passes into the circular endodermal columnar muscles where the most proximal meshes of the sphincter are located between the folds of the endodermal circular muscles (Fig. 22E).

The mesogloeal radial muscles of the oral disc and the longitudinal muscles on the oral side of the tentacles are very strong. They are visible by naked eye on the intact specimen as thick bands running side by side radially over the whole oral disc and continuing over the oral side of the tentacles (Fig. 21B). In the histological sections they appear as characteristically arranged muscle cords occupying almost the whole thickness of the mesogloea in the most parts of the oral disc (Fig. 23D), but running closer to its ectodermal side on the periphery of the oral disc (Fig. 23E) and in the tentacles (Fig. 23F). Longitudinal muscles not present on aboral side of the tentacles (Fig. 23F).

The mesenteries are arranged into four cycles, 48 pairs (Fig. 25A), 24 pairs of the mesenteries of the first three cycles are sterile and present along the whole length of the column. All sterile mesenteries, including two pairs of directives, have filaments. The mesenteries of last cycle (24 pairs) are weak, fertile, lack filaments, present only in the proximal half of column and regularly alternate with the sterile pairs of the mesenteries (Fig. 23A, C). The first cycle consists of six pairs of perfect mesenteries. The second cycle consists of four pairs perfect mesenteries, four unequal pairs composed of one perfect and one imperfect mesentery and two pairs imperfect 


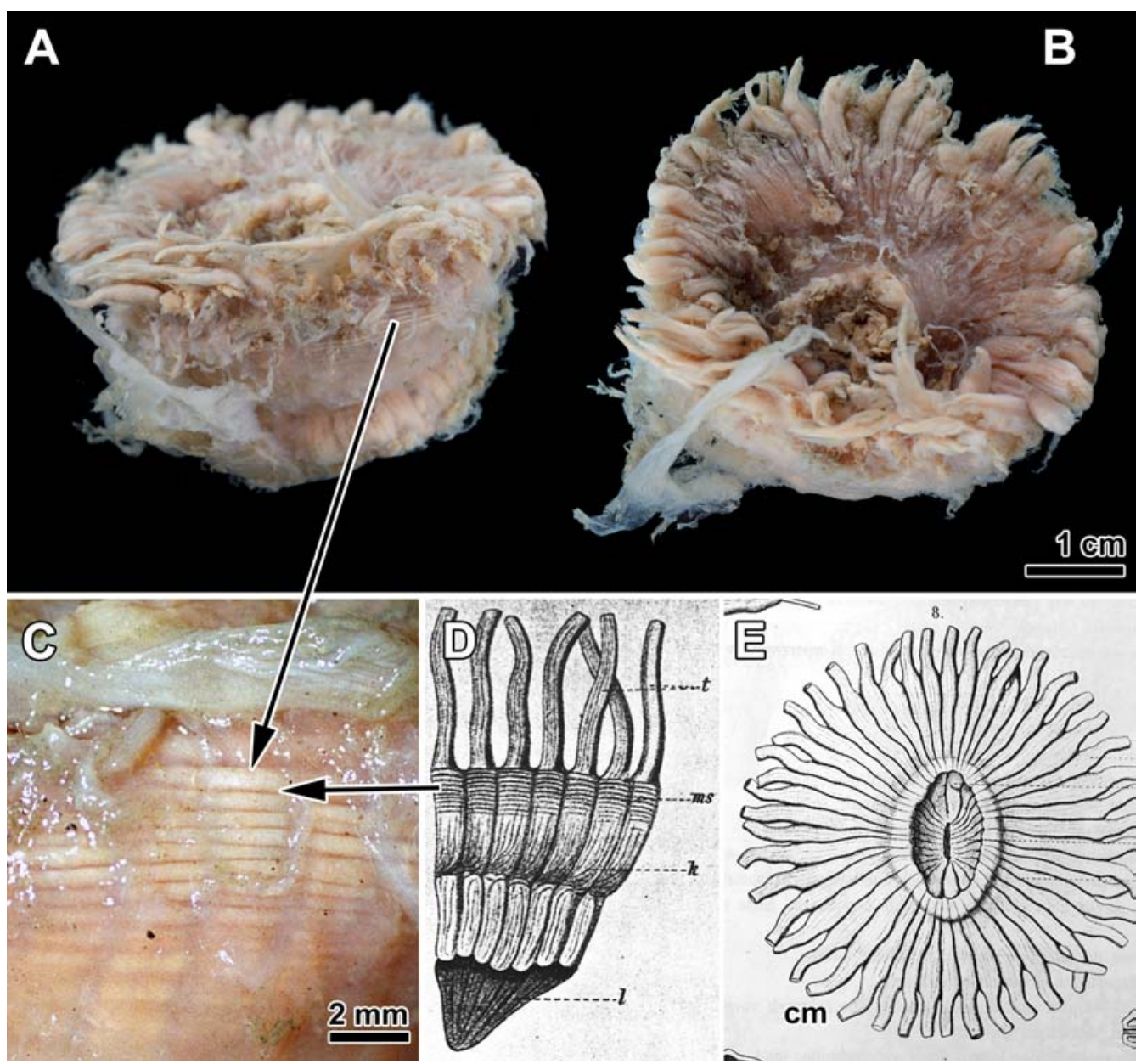

Fig. 21. A-C - Ophiodiscus moskalevi sp.n. A — side view; B - top view; C - annular folds of contracted marginal sphincter visible through the wall of column; D - Ophiodiscus annulatus, a portion seen from side, after Hertwig (1882, Pl. 10, fig. 1); E - Ophiodiscus sulcatus, greatly restored, after Hertwig (1882, Pl. 3, fig. 8).

Рис. 21. А-С-Ophiodiscus moskalevi sp.n. А - вид сбоку; В - вид сверху; С - складки сокращенного маргинального сфинктера видны сквозь стенку тела на фиксированном экземпляре; D - Ophiodiscus annulatus, участок тела, вид сбоку, по Hertwig (1882, Pl. 10, fig. 1); Е — Ophiodiscus sulcatus, реконструкция, по Hertwig (1882, Pl. 3, fig. 8).

mesenteries. They are distributed bilaterally and symmetrically in relation of directive plane: each of two imperfect pair is located in the "dorsal" primary exocoels, one perfect and one unequal pair in four other exocoels - in two lateral and two "ventral" primary exocoels (Fig. 25A). In each of the four unequal mesenterial pairs of the second cycle the imperfect mesentery is closer to the nearest pair of the first cycle, i.e. the perfect mesentery is faced by its retractor to the mesenterial pair of the preceding cycle, as in Actinostola-rule as it is characteristic for Tetracoelactis with the bilateral mode of the development of the mesenteries. Sterile mesenteries of the third cycle are imperfect and present only in two lateral and two "ventral" primary exocoels (two pairs in each exocoel), arranged symmetrically in relation to the directive plane. Only three pairs of mesenteries are present in each primary "dorsal" exocoels: a pair of imperfect sterile mesenteries of the second order, and two pairs of fertile mesenteries of the last 

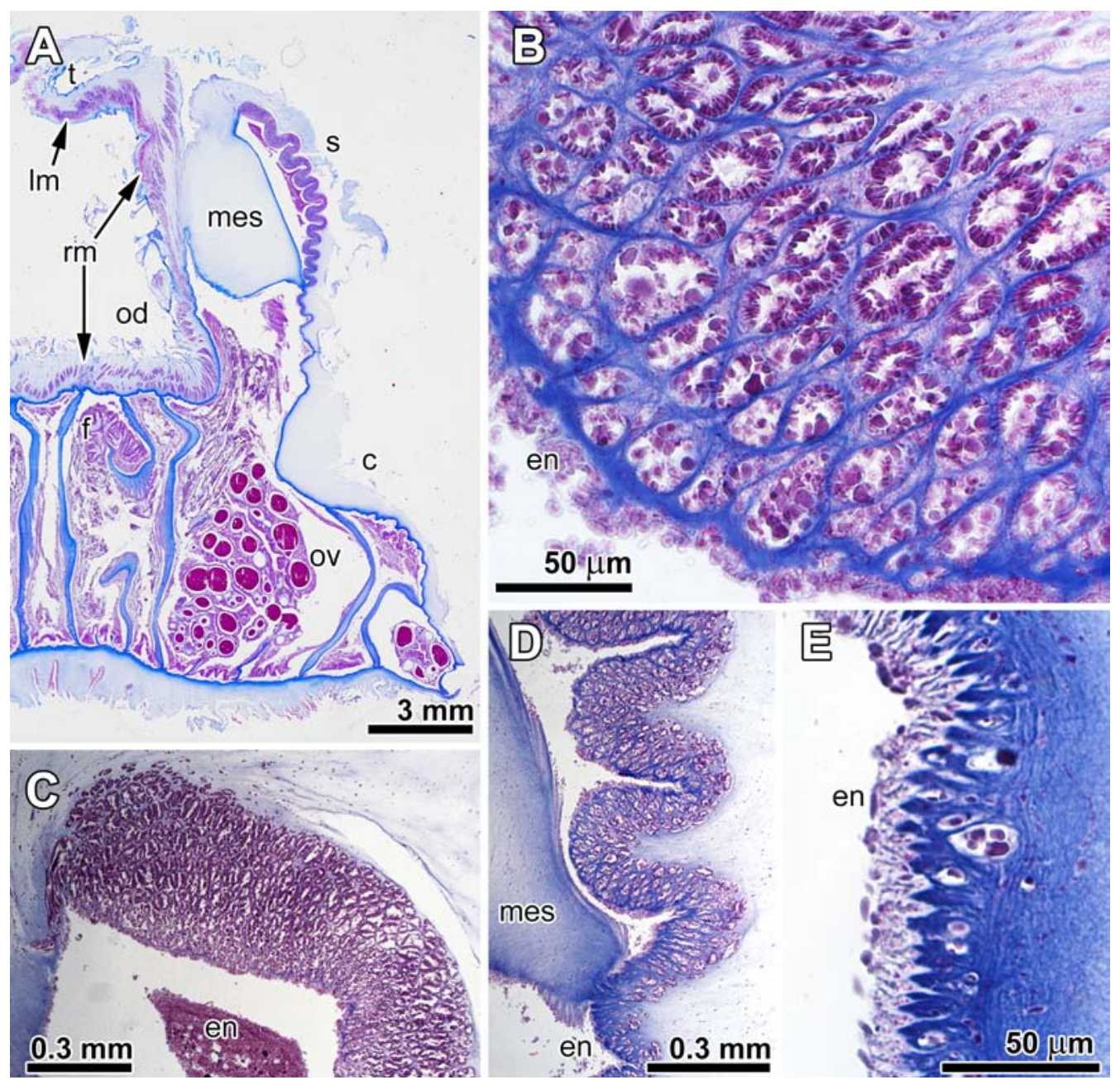

Fig. 22. Ophiodiscus moskalevi sp.n. A - longitudinal section of a specimen; B — detail of spincter muscle; $\mathrm{C}$ - distal part of the sphincter; D - middle part of the sphincter; E - proximal part of the sphincter. Abbreviations: c - column; en — endoderm; $\mathrm{f}$ - filaments; $1 \mathrm{~m}$ - longitudinal mesogloeal muscles of the tentacle; mes - mesentery; od - oral disc; ov — ova; rm — radial muscles of the oral disc; $\mathrm{s}$ - sphincter; $\mathrm{t}$ - tentacle.

Рис. 22. Ophiodiscus moskalevi sp.n. А - продольный срез; В - структура маргинального сфинктера; $\mathrm{C}$ - дистальный конец сфинктера; D - средний участок сфинктера; Е - проксимальный конец сфинктера.

Сокращения: c - колюмн; en - ентодерма; $\mathrm{f}$ - филаменты; $\mathrm{lm}$ - продольная мезоглеальная мускулатура щупальца; mes — мезентерий; od — оральный диск; ov — яйца; rm — радиальная мускулатура орального диска; $\mathrm{s}$ - сфинктер; $\mathrm{t}$ - щупальце.

cycle (here they belong to the third order) on each side of it. Thus the whole specimen is bilaterally symmetric in relation of the directive plane.

All sterile mesenteries have a corner of a very thick mesogloea near the margin of the oral disc (Fig. 23E). Retractor muscles of sterile mesenteries are diffuse and weak, up to $300 \mu \mathrm{m}$ in width (Fig. 24A).
Fertile mesenteries have small retractor up to $100 \mu \mathrm{m}$ in width, composed of mesogloea with included in it muscle meshes and only a few mesogloeal processes that resemble an endo-mesogloeal type of the musculature (Fig. 24D). The parietobasilar muscles are very weak. On the perfect mesenteries in the proximal part of the column (below the actinopharynx, 

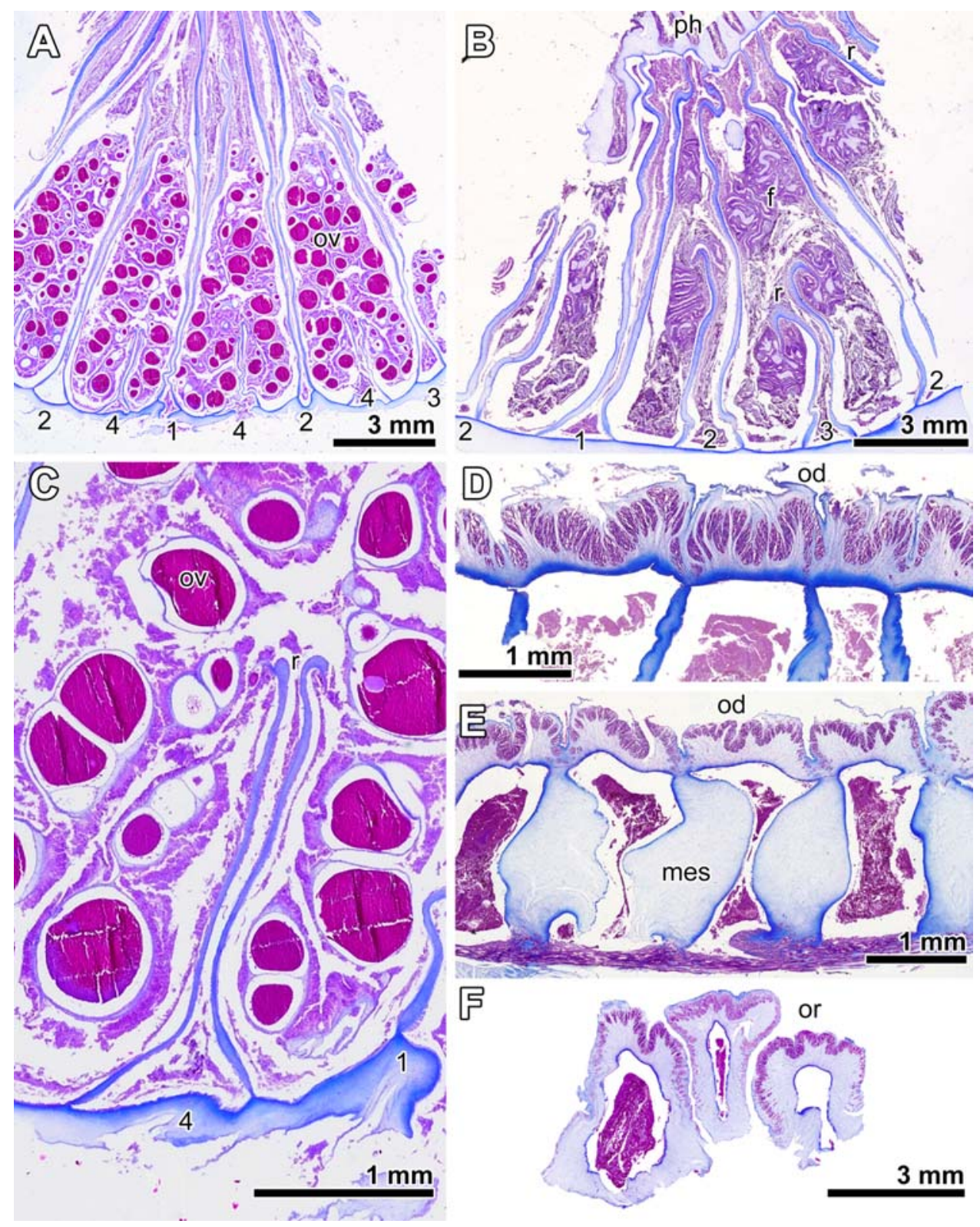

Fig. 23. Ophiodiscus moskalevi sp.n. A - transverse section of proximal part of column of the column; B transverse section of the column on the level of actinopharynx; C - fertile mesenteries; D - transverse section of the oral disc; E - transverse section in the distal part of the body through the oral disc and the wall of column; $\mathrm{F}$ - transverse section of the tentacles.

Abbreviations: ec — ectoderm; f — filaments; mes — mesentery; od — oral disc; or — oral side of the tentacles; ov ova; $\mathrm{r}$ - retractors. Numbers indicate cycle number of mesenterial pairs.

Pис. 23. Ophiodiscus moskalevi sp.n. А - поперечный срез в проксимальной части колюмна; В поперечный срез через колюмн на уровне глотки; $\mathrm{C}$ - фертильные мезентерии; D — поперечный срез через оральный диск; E - поперечный срез в дистальной части через оральный диск и стенку колюмна; F - поперечный срез через щупальца.

Сокращения: ec - эктодерма; f - филаменты; mes - мезентерии; od — оральный диск; or — оральная сторона щупалец; ov — яйца; $\mathrm{r}$ - ретракторы. Цифрами обозначены номера циклов мезентериальных пар. 


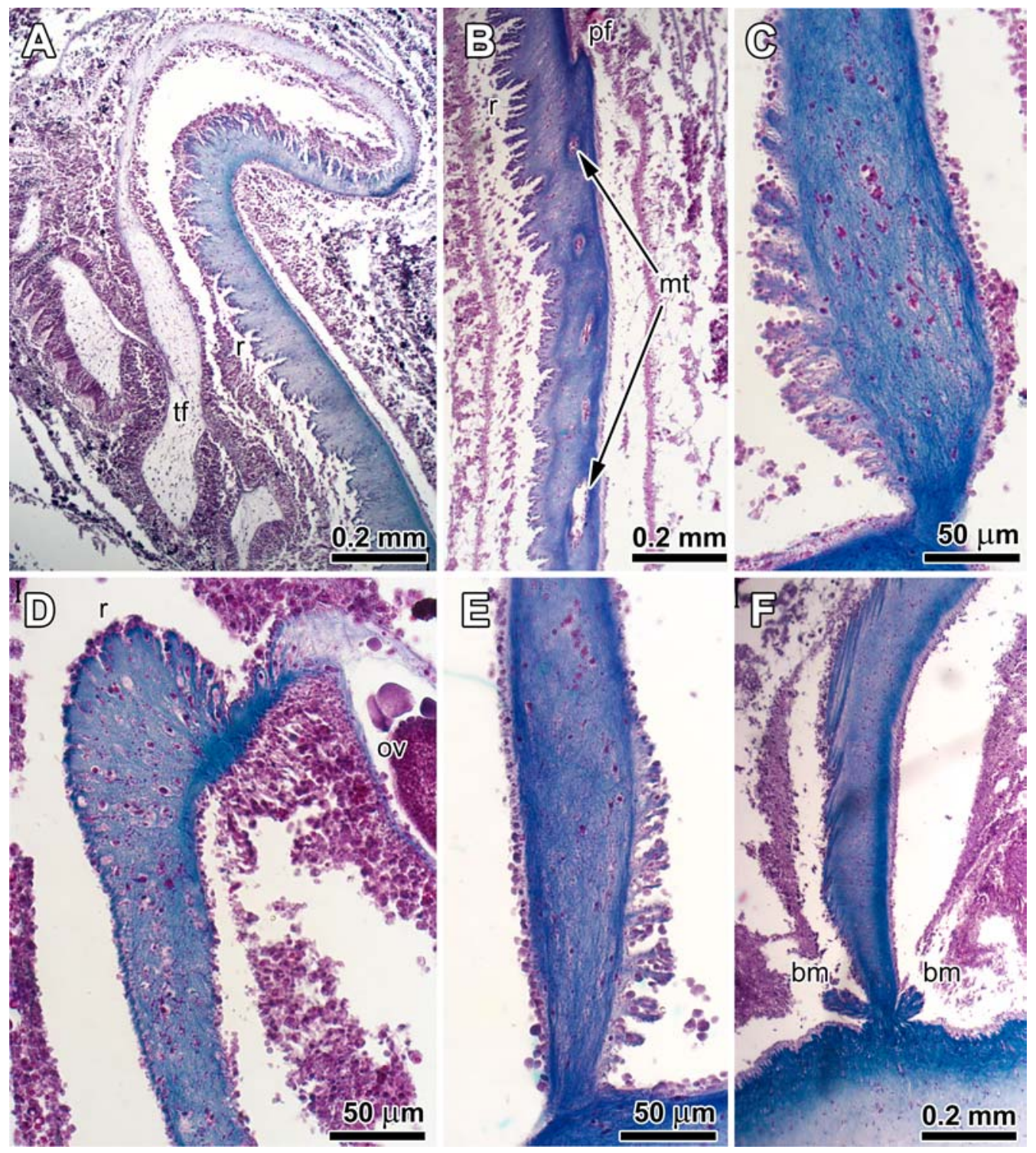

Fig. 24. Ophiodiscus moskalevi sp.n. A - retractor of the sterile mesentery; B - parieto-basilar part of the sterile mesentery; $\mathrm{C}$ - parietal part of the sterile mesentery; D - retractor of the fertile mesentery; E parietal part of the fertile mesentery; $\mathrm{F}$ - basilar muscles.

Abbreviations: $\mathrm{bm}$ - basilar muscles; $\mathrm{fl}$ - the parieto-basilar flap; $\mathrm{mt}$ - meshes of transverse muscles in the middle of the mesogloea of the mesentery; ov — ova; $\mathrm{r}$ - retractor; $\mathrm{tf}$ - trilobate filament.

Рис. 24. Ophiodiscus moskalevi sp.n. А - ретрактор стерильного мезентерия; В - парието-базилярная часть стерильного мезентерия; C - париетальная часть стерильного мезентерия; D - ретрактор фертильного мезентерия; Е - париетальная часть фертильного мезентерия; F — базальная мускулатура.

Сокращения: $\mathrm{bm}$ - базальная мускулатура; $\mathrm{fl}$ - парието-базилярный выступ; $\mathrm{mt}$ - ячейки поперечной мускулатуры в середине мезоглеи мезентерия; ov — яйца; $\mathrm{r}$ - ретрактор; tf — трилобатный филамент. 

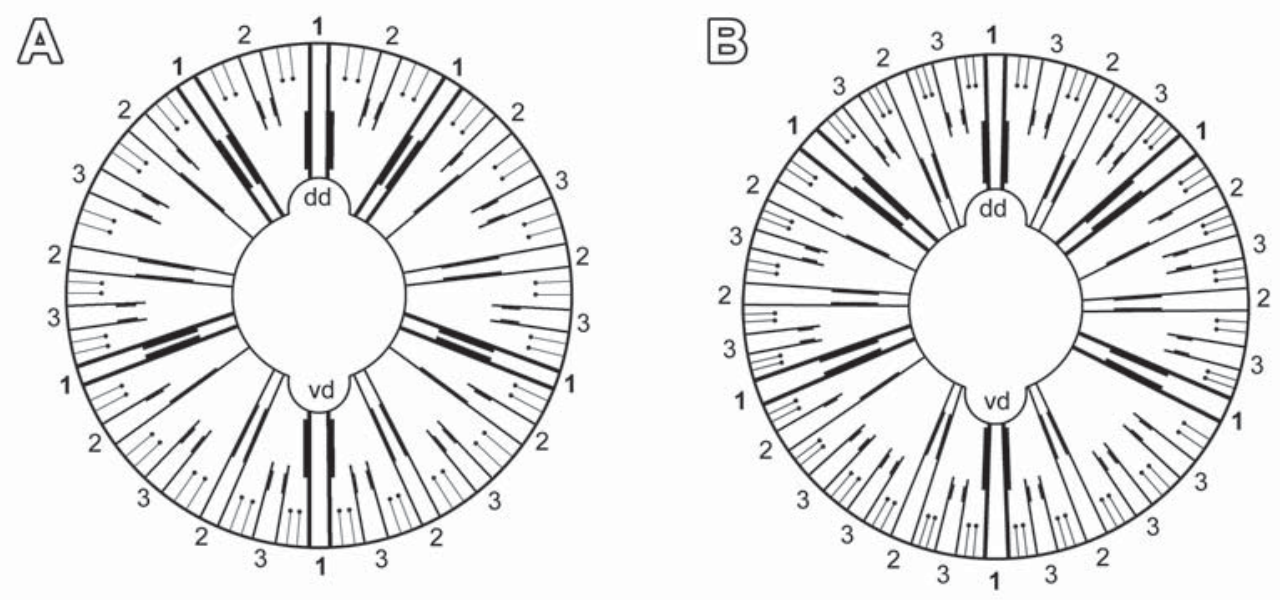

Fig. 25. Arrangement of the mesenteries. A — Ophiodiscus moskalevi sp.n.; B -Ophiodiscus bukini sp.n. Numbers indicate cycle number of sterile mesenterial pairs. Gonads are marked by small black circles on the end of the mesenteries of the last cycle.

Abbreviations: dd — "dorsal" directives; vd — "ventral" directives.

Рис. 25. Организация мезентериев. А 一 Ophiodiscus moskalevi sp.n.; В — Ophiodiscus bukini sp.n. Цифрами обозначены номера циклов стерильных мезентериальных пар. Гонады обозначены черными кружочками на концах мезентериев последнего цикла. Сокращения: $\mathrm{dd}$ - “дорсальные” направляющие пары мезентериев; vd - "вентральные" направляющие пары мезентериев.

where fertile mesenteries are present) they may form short flap (up to $100 \mu \mathrm{m}$ ). A chain of muscle meshes (transverse muscles) continues from a parieto-basilar flap in the parietal direction in the mesogloea of the mesentery on a distance of about $3 \mathrm{~mm}$ (Fig. 24B). The most parietal (on a distance 200-300 $\mu \mathrm{m}$ from the body wall) part of the longitudinal musculature on the side of retractor is formed by 10-15 noticeable, slightly branched muscle processes, up to $35 \mu \mathrm{m}$ in length on sterile (Fig. $24 \mathrm{C}$ ) and up to 25 $\mu \mathrm{m}$ on fertile mesenteries (Fig. 24E). The opposite side of the mesentery has no such enlargement of the parietal section of the musculature. The stomata are not found and probably not present. The mesogloea in the trilobate filaments is thick, up to $100 \mu \mathrm{m}$ (Fig. 24A). In the unilobate filaments it is much thinner. Basilar muscles are well-developed (Fig. 24F). The gonads, containing large ova (up to 800 $\mu \mathrm{m}$ in diameter), are profusely developed (Fig. 23A, C).

Cnidom includes spirocysts, basitrichs, $p$-mastigophores A, $p$-mastigophores B1 (Tab. 5, Fig. 26). It was not possible to study nematocysts on the margin because its ectoderm was abraded. The tentacles and the oral disc are not distinguishable by their cnidae: they contain spirocysts and basitrichs of the same size ranges and abundance (Fig. 26C, D). Some larger spirocysts have unevenly laid tubule but they are not considered as belonging to another type. The cnidoglandular tracts of unilobate filaments contain p-mastigophores A and B1 (Fig. 26G, H) while the small basitrichs, similar to those of the endoderm (Fig. 26 I), which occur on macerated samples of filaments, are present actually in the endoderm of the mesenteries near the cnidoglandular tracts, where they are common (60 cnidae measured). $P$-mastigophores A in the actinopharynx and filament (Fig. $26 \mathrm{~F}, \mathrm{G})$ are of the same size, have thin-walled capsule without apical flap; undischarged shaft is 15-25 $\mu \mathrm{m}$ and has 23-26 spiral turns of rows of spines. $P$-mastigophores B1 (Fig. $26 \mathrm{H}$ ) occurs only in the filaments, has a thick-walled capsule and three-lobed apical flap; undischarged shaft is 14-19 $\mu \mathrm{m}$ and has 12-17 spiral turns of rows of spines.

HABITAT. Abyssal species, occurs on soft muddy bottom. The label states: "the ground: gray-green pearlite mud, tubes of foraminifers Bathysiphon Sars, 1872". In live the oral disc probably is widely expanded, lies on the bottom and represents one "catching" surface (nematocysts of the tentacles and of the oral disc are the same).

ETYMOLOGY. The species named after Lev I. Moskalev who was a great scientist, a legendary person in Russian bio-oceanology. He took part in more than thirty, mostly deep-sea expeditions and collected of a huge number of samples, including the species described above. He, unfortunately, passed away at the end of 2020 . 


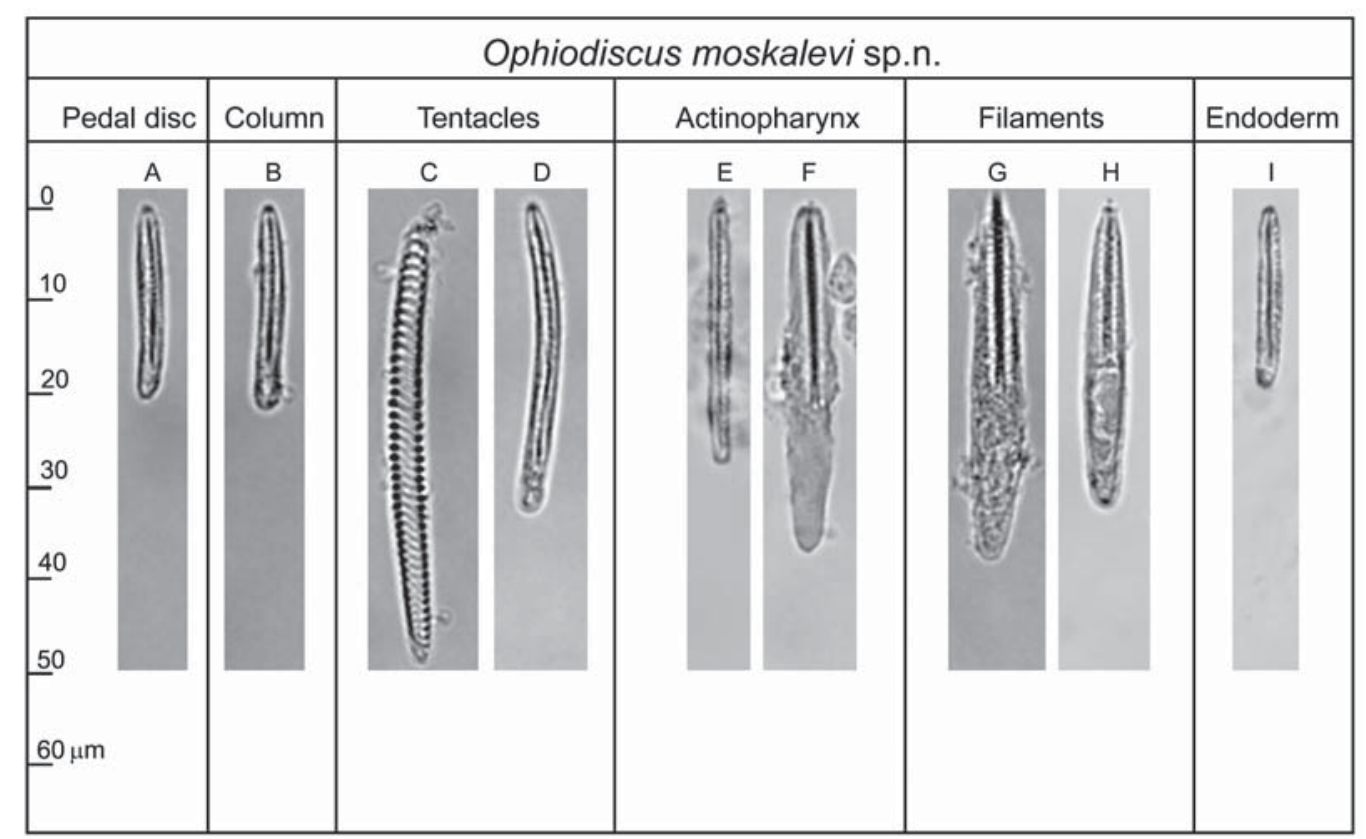

Fig. 26. Ophiodiscus moskalevi sp.n., distribution of cnidae (see Table 5 for size ranges).

Рис. 26. Ophiodiscus moskalevi sp.n., распределение книд (размеры указаны в табл. 5).

REMARKS. Described above species closely resembles two species on which Hertwig (1882) based his genus Ophiodiscus. Hertwig's (1882) material was in a very poor condition, he remarked that the specimens were fixed in chromic acid and the state of preservation was extremely unsatisfactory. Nevertheless, he was able to observe and describe in details some peculiar features allowing identification of described above specimen as a member of the genus Ophiodiscus. The sinuous shape of the sphincter (in preserved condition) is unusual and characteristic (compare Hertwig's, 1882 figures reproduced here and photographs of the present specimen, see Fig. 21). Hertwig (1882) described and figured numerous circular furrows caused by the sphincter on the distal part of column, this feature is quite evident in the present specimen (Fig. 21A, C). The mesogloeal muscles on transverse sections of the oral disc of O. annulatus (Hertwig 1882, Plate X, Fig. 5) are peculiarly curved and very similar to those of $O$. moskalevi sp.n. (Fig. 23D). Hertwig (1882) says that his drawing of the exterior of $O$. sulcatus is greatly restored and schematic (see Fig. 21E), nevertheless it closely resembles our specimen (Fig. 21B). Both species described by Hertwig (1882) have the same number of mesenteries as the present species (24 sterile filament-bearing pairs running over the whole column and 24 fertile filament lacking pairs in prox- imal part of column only). Hertwig (1882) reported about 100 tentacles for $O$. annulatus but from his description and figure he gave (Plate X, Fig. 3 ) it is clear that this is a mistype, both his species have 48 tentacles.

SPECIES LEVEL COMPARISON. In contrast with O. moskalevi sp.n. both Hertwig's (1882) species have pedal disc much smaller than the oral disc. The distribution of the mesenteries in $O$. annulatus, appear be more regular than in the present species. Hertwig (1882) explicitly stated that the sterile mesenteries in his species are distributed in three cycles, two cycles (12 pairs) are perfect while mesenteries of third cycle, 12 pairs, are imperfect. In $O$. moskalevi sp.n. pairs of sterile mesenteries are distributed in another way (Fig. 25A), ten of them are perfect and four are unequal, composed of one perfect and one imperfect mesentery, a feature not mentioned by Hertwig (1882). According to Hertwig (1882) small fertile mesenteries of $O$. annulatus follow Actinostola-rule: "The septa of a reproductive pair are always unequal in size, and that one of them is always the largest which stands next the muscular septum of the higher order" (Hertwig 1882: 60). In O. moskalevi sp.n. individual mesenteries in fertile pairs are not arranged according to the Actinostola-rule (Fig. 23C). It is possible that due to poor state of his material Hertwig's (1882) interpretation 
Table 6. Size ranges (length $\times$ width, in microns) and distribution of cnidae of Ophiodiscus bukini sp.n. Letters in brackets correspond to letters in Fig. 30.

Таблица 6. Размеры (длина $\times$ ширина, в микронах) и распределение стрекательных капсул Ophiodiscus bukini sp.n. Буквы в скобках соответствуют буквам на рис. 30.

\begin{tabular}{lll}
\hline Body region & Cnidae & Size ranges $(\mu \mathrm{m})$ \\
\hline Pedal disc & (A) basitrichs (common) & $17-23 \times 2-3$ \\
\hline Column & (B) basitrichs (common) & $18-25 \times 2-3$ \\
\hline \multirow{2}{*}{ Tentacles } & (C) spirocysts (very numerous) & $23-77 \times 2-6$ \\
& (D) basitrichs (numerous) & $27-39 \times 2.5-3.5$ \\
\hline \multirow{2}{*}{ Actinopharynx } & (E) basitrichs (common) & $20-34 \times 2-3.5$ \\
& (F) p-mastigophores A (few) & $29-35 \times 4.5-5.5$ \\
\hline \multirow{2}{*}{ Filaments } & (G) $p$-mastigophores A (common) & $26-36 \times 4.5-6$ \\
& (H) $p$-mastigophores B1 (numerous) & $26-36 \times 4-5$ \\
\hline Endoderm & (I) basitrichs (see text) & $11-21 \times 2-3$ \\
\hline
\end{tabular}

of the arrangement mesenteries and his assumption that fertile mesenteries follow Actinostola-rule are not correct, but his statement may be verified only if new specimens of his species will be collected in type locality. Taking in account morphological differences discussed above and a huge geographic distance between the records of Hertwig's (1882) species and $O$. moskalevi sp.n. (off Chile and off Kamchatka) we infer their conspecificity unlikely and describe our specimen as a new species.

The anatomy of the second Hertwig's (1882) species, $O$. sulcatus, is worse known because it "was so completely tattered that a superficial examination could hardly recognize an Actinia in the whitish mass" (Hertwig 1882: 61). Hertwig (1882: 62) suggested that it may be identical with $O$. annulatus, and indeed, all reported features are similar, the only difference, which may be reliable, is the shape and the size of the sphincter, which is weak in $O$. sulcatus and forms no characteristic plications ("absence of annulation" of the distal column).

\section{Ophiodiscus bukini sp.n.}

Table 6; Figs 25B, 27-30.

MATERIAL EXAMINED. Holotype MIMB 41370, RV Akademik M.A. Lavrentyev, 75 cruise, St. 21, sample 9, 01 July 2016, NW Pacific, the south-west Bering Sea, in the northern slope of the Volcanologists Massif, $55.47725^{\circ} \mathrm{N}, 167.251472^{\circ} \mathrm{E}$, 2732 m, ROV Comanche 18 NSCMB FEB RAS, one specimen.

DESCRIPTION. Four specimens were photographically documented by ROV, one was collected. Live specimens are disc-shaped, the short column is completely hidden under the very wide oral disc, its diameter is estimated as $20 \mathrm{~cm}$ (Fig. 27A, B). Preserved and contracted specimen has a form of a short cylinder, $9 \mathrm{~cm}$ in diameter and $5 \mathrm{~cm}$ high (Fig. 27C, D). In live it was monotonous light rose-beige with slightly darker radial lines on the oral disc over the mesenterial insertions. In formalin all parts of the body are dirty-white, some brown pigment present only on the inner lining of the actinopharynx (excluding siphonoglyphs) and in the endoderm of the mesenteries along the unilobate filaments (Fig. 28A).

The pedal disc is circular, concave, of the same diameter as column, with fine radial ridges between the insertions of the mesenteries on the periphery of the disc (Fig. 28A), without remnants of cuticle.

The column has a transverse circumferential furrow in the middle (Fig. 27D). The distal part of column cannot cover the tentacles (Fig. 27C). The surface of the most part of the column is more or less smooth, with shallow irregular wrinkles in preservative caused by contraction; short shallow longitudinal furrows corresponding to the insertions of the mesenteries are present at its most proximal part. The ectoderm of the column is mostly retained, very thin. The mesogloea is about $5 \mathrm{~mm}$ thick in most part of the column, thinner at limbus, especially along the border between the columnar wall and the pedal disc, and at distal part of the column: in distal part of the column it is up to $3 \mathrm{~mm}$ (as in aboral side of the tentacles).

The number of the tentacles is rather constant: 56, 56, 57 and 58 (in the holotype) tentacles were counted in four specimens on underwater photographs. They are short, conical, sharply pointed in live, blunt in preservative, all of the same size, 

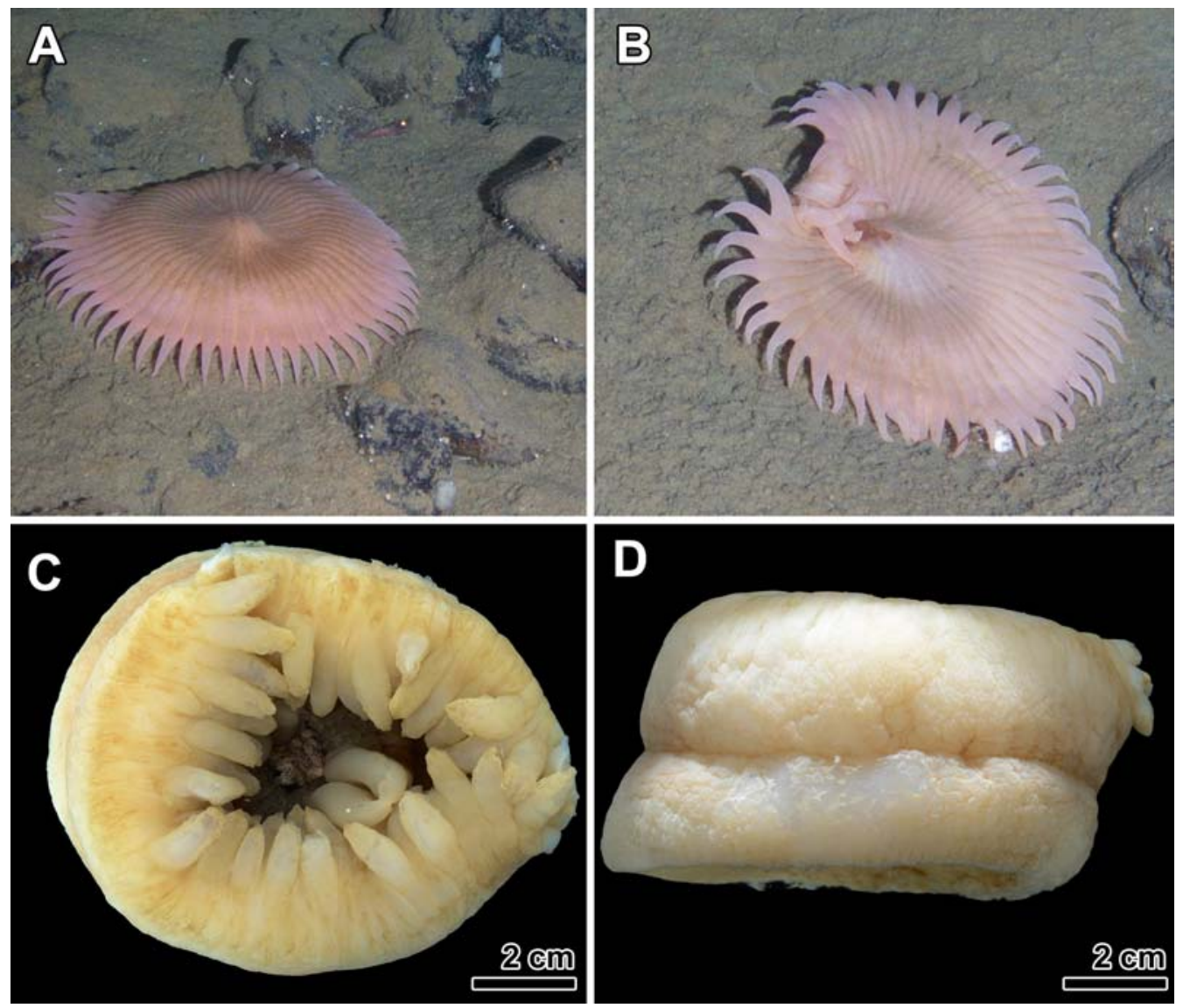

Fig. 27. Ophiodiscus bukini sp.n. A-B - specimens in natural environment, photo ROV Comanche 18 NSCMB FEB RAS; C - preserved holotype, top view; D - preserved holotype, side view.

Рис. 27. Ophiodiscus bukini sp.n. А-В - живые экземпляры, фото ТНПА Comanche 18 ННЦМБ ДВО РАН; C — фиксированный голотип, вид сверху; D - фиксированный голотип, вид сбоку.

arranged in a single circle on the margin. In live the tentacles are lying horizontally on the substratum (Fig. 27A, B). The tentacles are thick walled, the mesogloea is thicker along the whole aboral side but special aboral mesogloeal thickenings at base are not present (Figs 28B, 29D). The thickness of the mesogloea on the aboral side of the tentacles is the same as in distal column and its thickness on the oral side is the same as in oral disc (Fig. 28B).

The oral disc in live is more or less flat with slightly raised oral cone. Its surface is radially ridged: the insertions of the mesenteries are marked by narrow radial furrows and the mesogloea over exoand endocoels is thickened forming a ridge clearly visible on live specimens (Fig. 27A, B). Exo- and endocoelic radial ridges are similar in the size and shape.
The actinopharynx has two very large thickwalled siphonoglyphs, they are folded in the preserved material (Fig. 28A), and nine thick longitudinal mesogloeal ridges on each side between the siphonoglyphs.

The marginal sphincter muscle is weak, very thin in comparison with the thickness of the mesogloea (Fig. 28B), $0.4 \mathrm{~mm}$ in the widest distal part, gradually tapering proximally, rather long (up to $3 \mathrm{~cm}$, about a half of the column length, it almost reaches a circumferential fold on the column). It runs along the endodermal side of the mesogloea and forms endo-mesogloeal complex with the circular endodermal muscles of the column. Its distal part has several wide folds (Fig. 28B, C). The distal part of the sphincter is distinctly reticular, but it gradually becomes alveolar toward the proximal end (Fig. 

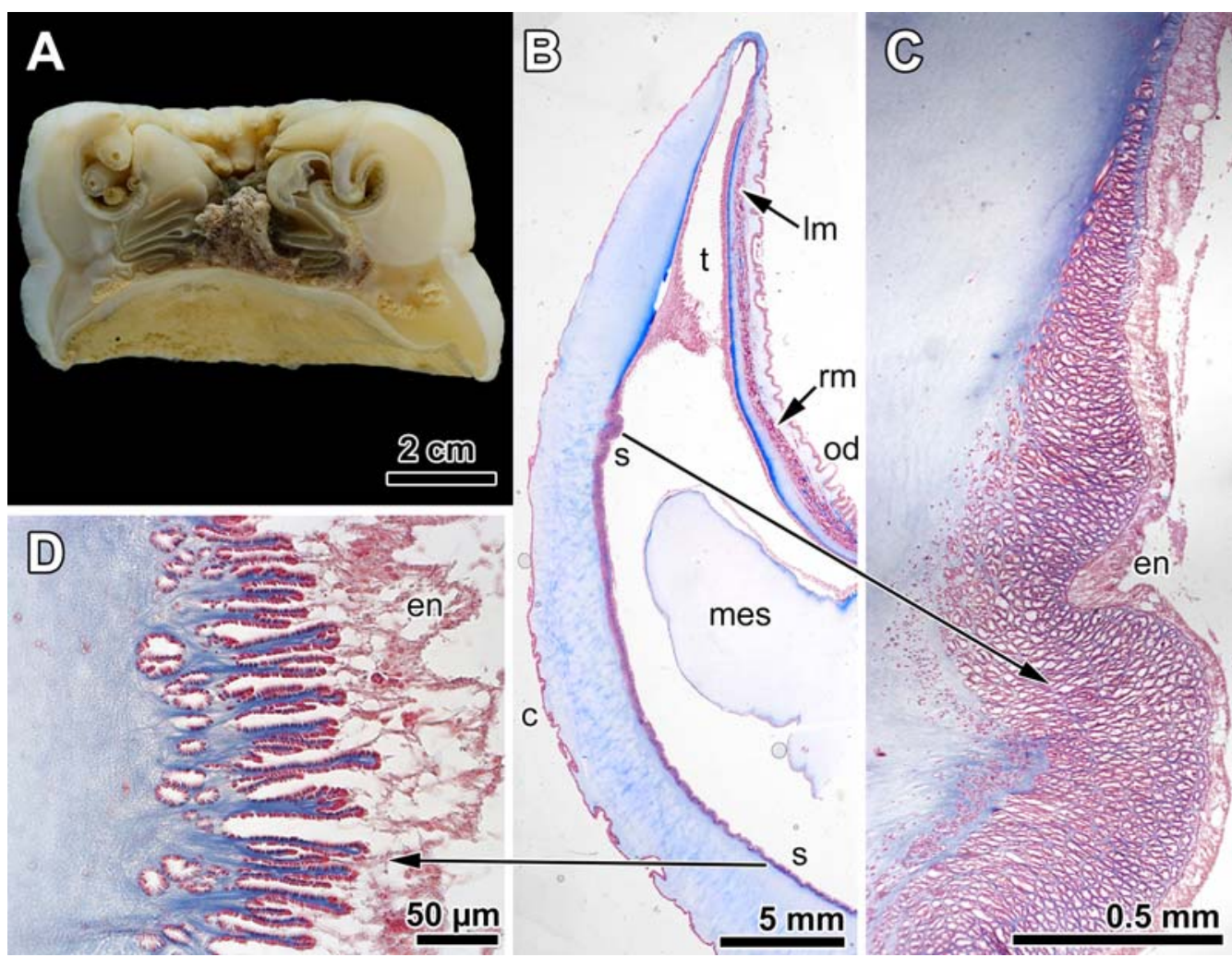

Fig. 28. Ophiodiscus bukini sp.n. A — longitudinal section of the whole specimen; B — longitudinal section through the distal part of column; C - distal part of the sphincter; D - proximal part of the sphincter. Abbreviations: $\mathrm{c}$ - column; en — endoderm; $1 \mathrm{~m}$ — longitudinal mesogloeal muscles of the tentacle; mes — mesentery; od — oral disc; ov — ova; rm — radial muscles of the oral disc; $\mathrm{s}$ - sphincter; sp — siphonoglyph; $\mathrm{t}$ - tentacle.

Рис. 28. Ophiodiscus bukini sp.n. А - продольный срез; В — продольный срез через верхнюю часть колюмна; C - дистальный конец сфинктера; D - проксимальный участок сфинктера.

Сокращения: c - колюмн; en - ентодерма; $1 \mathrm{~m}$ - продольная мезоглеальная мускулатура щупальца; mes мезентерий; od - оральный диск; ov — яйца; rm - радиальная мускулатура орального диска; s - сфинктер; $\mathrm{sp}$ - сифоноглиф; $\mathrm{t}$ - щупальце.

28D). Circular endodermal muscles are well developed in the middle and proximal parts of the column (Fig. 28D). The radial muscles of the oral disc are mesogloeal and strong, arranged into thick separate bundles running over each exo- and endocoel, on equal distance from ecto- and endodermal sides of the mesogloea (Fig. 29B). The longitudinal muscles of the tentacles are mesogloeal and present only on the oral side (Fig. 29D). They have the same structure and thickness as the radial muscles of the oral disc (Fig. 28B).

The mesenteries are arranged in four cycles. The mesenteries of the first three cycles are sterile and present along the whole length of the column. All sterile mesenteries, including two pairs of directives, have filaments. The mesenteries of the last (the fourth) cycle are weak, fertile, lack filaments, present only in the proximal half of column and regularly alternate with the sterile pairs of the mesenteries (Figs 25B, 29C).

The mesenteries are arranged in as $6+9+14+29=$ 58 pairs. The first cycle consists of six pairs of perfect mesenteries. The second cycle consists of six pairs perfect mesenteries and three unequal pairs composed of one perfect and one imperfect mesentery in two lateral and one "ventrolateral" primary exocoels (Fig. 25B). The mesenteries of the third cycle are imperfect. Third cycle of the mesenteries has two duplications arranged symmetrically in relation to the directive plane. Thus the arrangement of the mesenteries is bilateral, the symmetry is deviated only by the absence of an additional pair of unequal 

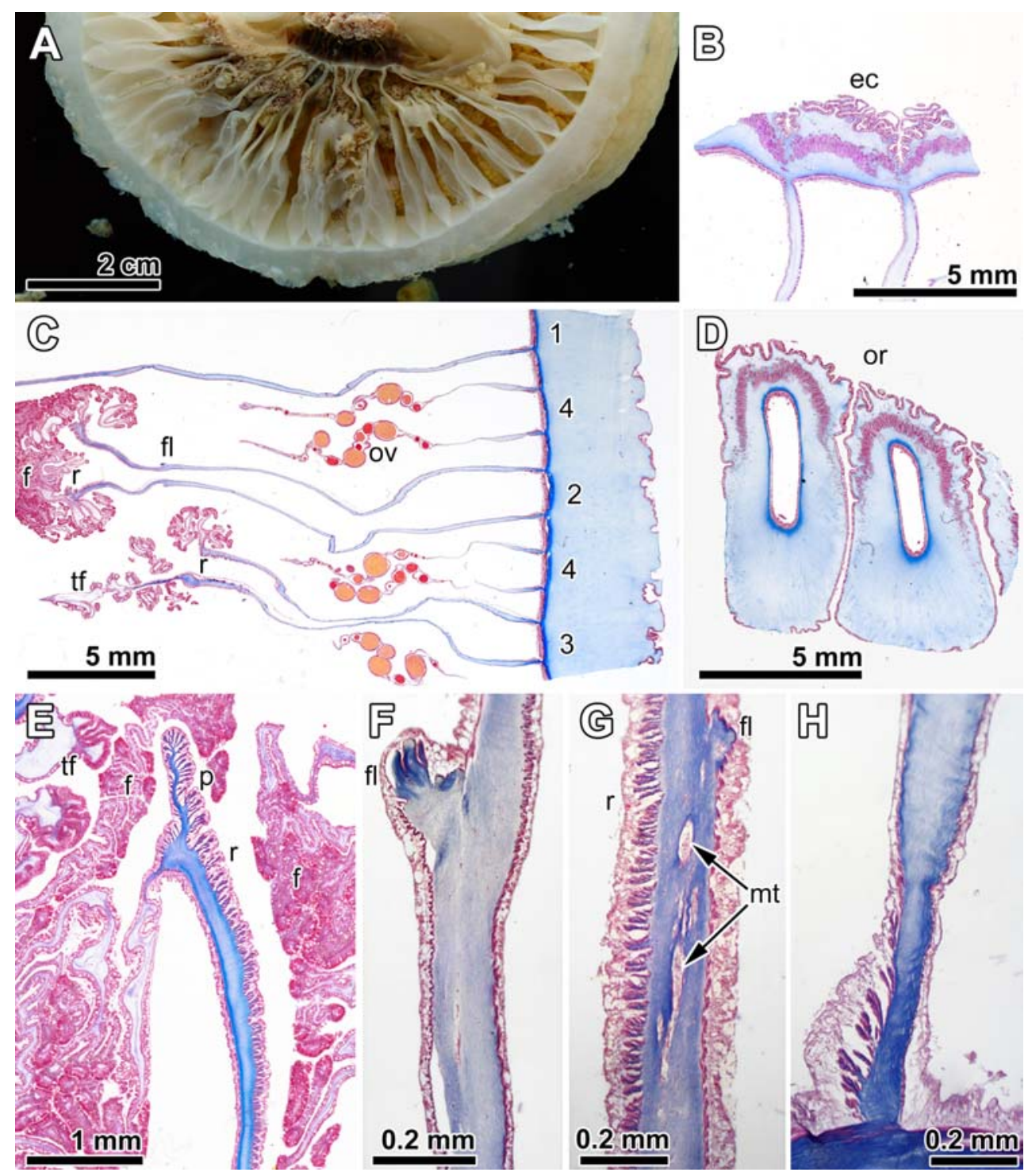

Fig. 29. Ophiodiscus bukini sp.n. A - transverse section of the half of column; B - transverse section of the oral disc; $\mathrm{C}$ - transverse section of the column; D - transverse section of the tentacles; $\mathrm{E}$ - retractor of the mesentery of the first cycle; F - parieto-basilar part of the mesentery of the second cycle; G - parietobasilar part of the mesentery of the first cycle; $\mathrm{H}$ - parietal part of the sterile mesentery of the first cycle. Abbreviations: ec - ectoderm; $\mathrm{f}$ - unilobate filaments; $\mathrm{fl}$ - the parieto-basilar flap; $\mathrm{mt}$ - meshes of transverse muscles in the middle of the mesogloea of the mesentery; or — oral side of the tentacles; ov — ova; $p$ - the pennon of the retractor; tf - trilobate filaments. Numbers indicate cycle number of mesenterial pairs.

Рис. 29. Ophiodiscus bukini sp.n. А - поперечный срез через половину колюмна; В — поперечный срез через оральный диск; C - поперечный срез через колюмн; D - поперечный срез через щупальца; $\mathrm{E}$ - ретрактор мезентерия первого цикла; $\mathrm{F}$ - парието-базилярный участок мезентерия второго цикла; $\mathrm{G}$ - парието-базилярный участок мезентерия первого цикла; Н - париетальная часть стерильного мезентерия первого цикла.

Сокращения: ec - эктодерма; $\mathrm{f}$ - унилобатные филаменты; $\mathrm{fl}$ - парието-базилярный вырост; $\mathrm{mt}$ - ячейки поперечной мускулатуры в середине мезоглеи мезентерия; or - оральная сторона щупалец; ov — яйца; $\mathrm{p}$ вырост ретрактора; $\mathrm{tf}$ - трилобатные филаменты. Цифрами обозначены номера циклов мезентериальных пар. 


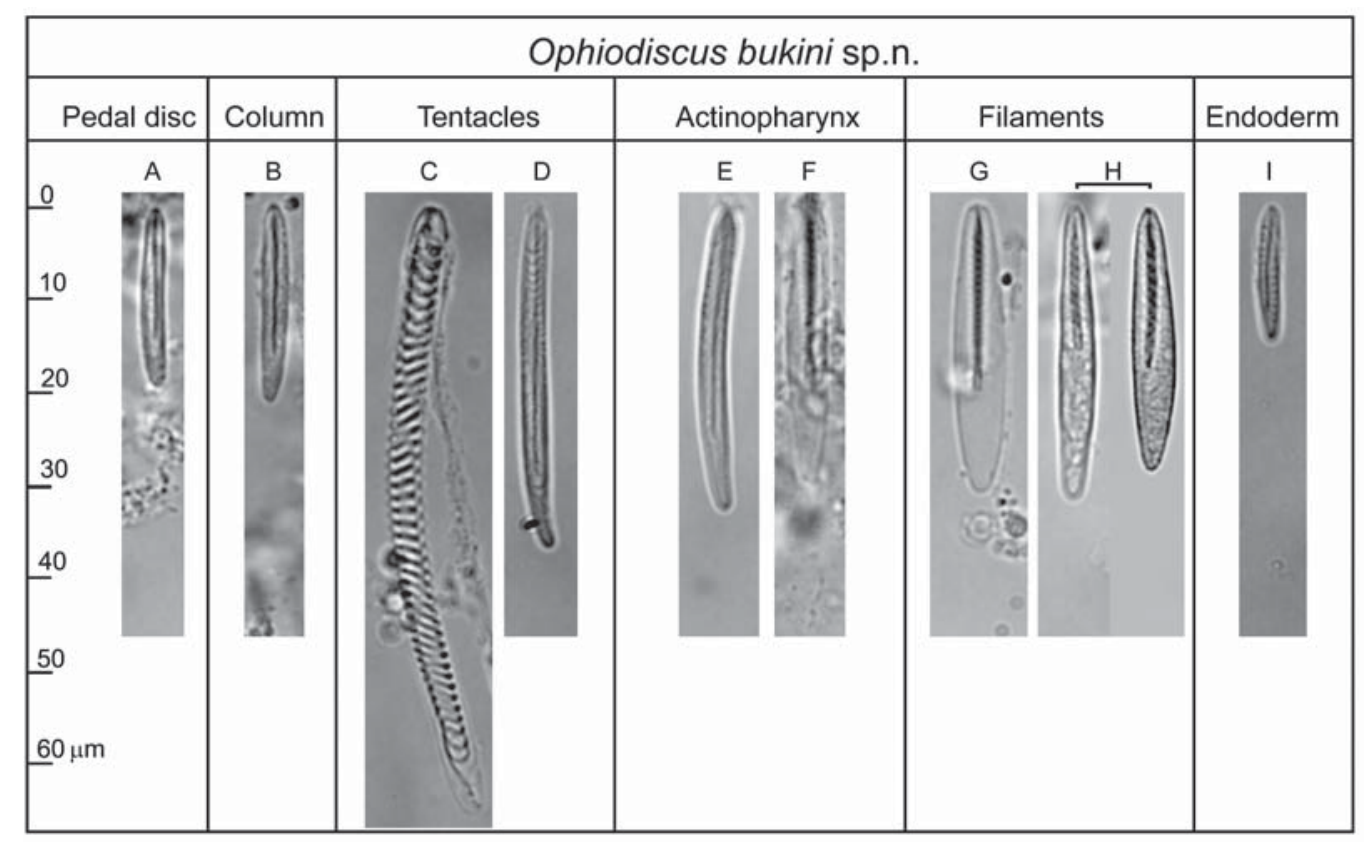

Fig. 30. Ophiodiscus bukini sp.n., distribution of cnidae (see Table 6 for size ranges).

Рис. 30. Ophiodiscus bukini sp.n., распределение книд (размеры указаны в табл. 6).

mesenteries of the second cycle in one "ventrolateral" primary exocoel (Fig. 25B).

The mesenteries of the first three cycles have a very thick mesogloea in the distal part of the column (Fig. 29A). In the proximal half of the column the mesogloea of all mesenteries is thin (Fig. 29C).

Retractor muscles are diffuse and weak, running along the adaxial (inner, closer to the actinopharynx) part of the mesenteries. Retractors of the mesenteries of the first two cycles may form a narrow flap, better developed on the mesenteries of the first cycle (up to $1 \mathrm{~mm}$ long, Fig. 29E). Fertile mesenteries have very weak retractors represented by separate muscle fibres, but they may form a short (to $100 \mu \mathrm{m}$ ) flap on a small mesogloeal fold near the gonad. The parietobasilar muscles are very weak, may form short flaps, up to $100 \mu \mathrm{m}$, on the mesenteries of the first and the second cycles (Fig. 29F). Very small muscle meshes of transverse muscles are present in the mesogloea in the region of the parietobasilar muscles of the mesenteries of the first and the second cycles. They extend from the parieto-basilar flap in parietal direction on about $500-1000 \mu \mathrm{m}$. On the first cycle the chains of these meshes are longer than on the second cycle (Fig. 29G). The most parietal (closer to the body wall, on a distance of about $400-500 \mu \mathrm{m}$ from the body wall) part of the longitudinal musculature (on the side of the retractors) is formed by a few (8-
12) noticeable, slightly branched muscle processes (to $90 \mu \mathrm{m}$ in length) more or less equally developed on the mesenteries of all (sterile and fertile) cycles (Fig. 29H). On the opposite, parieto-basilar, side of the mesenteries such a strengthening of the parietal section of the musculature not developed.

The mesenteries have large oral stomata about 1 $\mathrm{cm}$ in diameter. The marginal or central stomata were not found. The mesogloea of the mesenteries near the trilobate filaments is several times thicker (300$500 \mu \mathrm{m})($ Fig. 29C, E) than near the in unilobate filaments (about $100 \mu \mathrm{m}$ ). The gonads, containing large ova, up to $1 \mathrm{~mm}$ diameter, are profusely developed (Fig. 29C).

Cnidom includes spirocysts, basitrichs, $p$-mastigophores A, $p$-mastigophores B1 (Tab. 6, Fig. 30). The most part of the column, apart from its distal part about $1 \mathrm{~cm}$ from margin, contains only one type of basitrichs (Fig. 30B). The distal part of the column, the tentacles and the oral disc are not distinguishable by their cnidae: they contain spirocysts and basitrichs of the same size ranges and abundance (Fig. $30 \mathrm{C}, \mathrm{D})$. Basitrichs in these regions often are slightly narrowed and curved at basal end (Fig. 30D). Some spirocysts have unevenly laid tubule in some (larger or smaller) part of the capsule but their capsules are of the same width as the capsules of the similar length having evenly laid tubule, thus we do not 
distinguish them as belonging to a separate robust type. The endoderm contains small basitrichs (Fig. $30 \mathrm{I}$ ), they are very rare in most regions, but are crowded in the endoderm of the tentacle tips, especially on the oral side. The cnidoglandular tracts of unilobate filaments contain $p$-mastigophores $\mathrm{A}$ and B1 (Fig. 30G, H) while the small basitrichs, similar to those from the endoderm (Fig. $30 \mathrm{I}$ ), which are present on macerated samples, are present actually in the endoderm of the mesenteries near the cnidoglandular tracts. Similar basitrichs are present in the cnidoglandular and reticular tracts of the trilobate filaments and in the endoderm of the mesenteries near them. All basitrichs and p-mastigophores B1 (Fig. 30H) are stained by basic stains in contrast with spirocysts and $p$-mastigophores A. $P$-mastigophores A in the actinopharynx and filaments (Fig. 30F, G) have thinwalled capsules of similar size without apical flap; undischarged shaft is $15-22 \mu \mathrm{m}$ and has 15-22 turns of rows of spines; discharged shaft becomes about two times longer. $P$-mastigophores B1 (Fig. $30 \mathrm{H}$ ) are present only in filaments. They have thick-walled capsule and three-lobed apical flap; undischarged shaft is $14-20 \mu \mathrm{m}$ and has 9-13 turns of rows of spines; sometimes the tip of the shaft is pointed.

HABITAT. The species lives unattached on soft bottom at lower bathyal depths. In live the oral disc is widely expanded, lies on the bottom and represents one «catching» surface.

ETYMOLOGY. The species is named after Ilya Bukin, a pilot of ROV Comanche 18 NSCMB FEB RAS who worked in both 75 and 85 cruises of RV Akademik M.A. Lavrentyev.

REMARKS. The present species differs from other Ophiodiscus species by larger number of mesenteries and tentacles: $O$. annulatus, $O$. sulcatus and $O$. moskalevi sp.n. all have 48 tentacles while all specimens of $O$. bukini sp.n., observed on underwater photographs, have larger and stable number of the tentacles $(56,56,57$ and 58). Large oral stomata are present in $O$. bukini sp.n., while O. moskalevi sp.n., which was collected much deeper, has no any kind of stomata. In live disc-shaped body of O. bukini sp.n. has some (rather distant) resemblance with Sicyonis heliodiscus, but they cannot be confused on the underwater photographs: the tentacles are different and arranged in two rows in S. heliodiscus.

\section{Family Anthosactinidae fam.n.}

DIAGNOSIS. Actiniaria with definite base and mesogloeal sphincter which is not separated from circular endodermal musculature of column. Acontia not present. Aboral sides of the bases of the outer tentacles have nematocyst batteries: a patches of thickened ectoderm with large crowded nematocysts (heterotrichs or holotrichs). Cnidom: spirocysts, heterotrichs, basitrichs, $p$-mastigophores A, $p$-mastigophores B1.

Included genera: Anthosactis Danielssen, 1890 (type genus), Hormosoma Stephenson, 1918 and Tealidium Hertwig, 1882.

Anthosactis, Hormosoma and Tealidium were previously classified in Actinostolidae on the basis of the presence of definite base, mesogloeal sphincter and absence of acontia. In his key to genera Carlgren (1949) placed them into a section uniting genera in which the mesenteries are not arranged according to the Actinostola-rule. The same section contained several other genera, some of which are certainly not related and not confamiliar with Actinostola, e.g. Paranthus Andres, 1883, with its peculiar drop-shaped nematocysts (our own data and see also López-Gónzalez, García-Gómez, 1994), or Antholoba Hertwig, 1882, which has strongly deviating position on molecular tree (see Rodríguez et al., 2012), or Actinoscyphia and Epiparactis which were removed from Actinostolidae into a separate family Actinoscyphiidae by Riemann-Zürneck (1978). Anthosactis, Hormosoma and Tealidium constitute a group of closely related to each other but morphologically distinctive genera which show no any traces of arrangement of the mesenteries according to the Actinostola-rule. In Bayesian Inference (BI) and Maximum Likelihood (ML) analyses these three genera form a separate clade with $100 \%$ bootstrap support in ML and posterior probability equal to 1 in BI trees (Fig. 38). As we already stated above (in comments under Sicyonidae) uniting together genera Actinostola, Stomphia, Sicyonis, Ophiodiscus, Anthosactis, Hormosoma and Tealidium, (and also, possibly, members of Exocoelactinidae, Capneidae and Halcampulactinidae which on molecular trees consistently resolved among them) in one family (Actinostolidae) would considerably obscure both morphological and molecular diversity and is not acceptable. In the present work we remove Anthosactis, Hormosoma and Tealidium from Actinostolidae and place them into a separate family Anthosactinidae fam.n. A restriction the family Actinostolidae to the genera in which the mesenteries are arranged to Actinostolarule (Actinostola, Stomphia and Glandulactis Riemann-Zürneck, 1978) is, actually, a revert to the original understanding of Actinostolidae by Carlgren (1893) who removed Actinostola and Stomphia from Paractinidae on the basis of this feature only, and is in agreement with the understanding of this group (as a subfamily) by Stephenson (1920).

Type genus of Anthosactinidae fam.n., Anthosactis, includes five species (Fautin, 2016, in her 
Table 7. Size ranges (length $\times$ width, in microns) and distribution of cnidae of Tealidium konoplinorum sp.n. (based on three specimens). Letters in brackets correspond to letters in Fig. 37. Таблица 7. Размеры (длина $\times$ ширина, в микронах) и распределение стрекательных капсул Tealidium konoplinorum sp.n. (по трем экземплярам). Буквы в скобках соответствуют буквам на рис. 37.

\begin{tabular}{lll}
\hline \multirow{2}{*}{ Body region } & Cnidae & Size ranges $(\mu \mathrm{m})$ \\
\hline \multirow{2}{*}{ Pedal disc } & (A) basitrichs (rare) & $17-18 \times 3$ \\
& (B) basitrichs (few) & $22-31 \times 4-5$ \\
\hline \multirow{3}{*}{ Column } & (C) basitrichs (rare) & $15-22 \times 2.5-3$ \\
& (D) basitrichs (common) & $21-35 \times 3.5-6$ \\
& (E) heterotrichs (rare) & $17-25 \times 5.7-7.5$ \\
& (F) holotrichs (rare) & $32-37 \times 9.5-13$ \\
& (G) p-mastigophores A (common) & $25-43 \times 3.2-8$ \\
\hline \multirow{3}{*}{ Tentacles } & (H) spirocysts (very numerous) & $27-83 \times 2.5-8$ \\
& (I) heterotrichs (common) & $29-40 \times 4-6.5$ \\
& (J) heterotrichs (batteries) & $95-124 \times 9.5-11.5$ \\
\hline \multirow{3}{*}{ Oral disc } & (K) spirocysts (common) & $30-56 \times 3-7.5$ \\
& (L) basitrichs (few) & $18-25 \times 2.7-3.7$ \\
& (M) heterotrichs (few) & $33-41 \times 4.5-6.5$ \\
\hline Actinopharynx & (N) p-mastigophores A (few) $p$-mastigophores A (few) & $24-29 \times 5-7$ \\
\hline \multirow{2}{*}{ Filaments } & (P) p-mastigophores A (common) & $24-30.5 \times 4.7-6.3$ \\
\hline Endoderm & (Q) p-mastigophores B1 (few) & $32-37 \times 3.5-5.5$ \\
\hline
\end{tabular}

catalogue, lists seven species, but one, $A$. pearseae Daly et Gusmão, 2007, was earlier removed from this genus by Rodríguez et al., 2012 and another, $A$. nomados White et al., 1999, is wrongly assigned to this genus as is apparent from its described morphology and cnidom). Type species of Anthosactis, A. janmayeni Danielssen, 1890, is an Arctic species, it was redescribed by Riemann-Zürneck (1997) in details. Four other Anthosactis species are poorly known and based only on the original descriptions. Hormosoma includes one species, H. scotti Stephenson, 1918. It is widely distributed in Antarctic and was redescribed by many authors (e.g. Dunn, 1983, Rodríguez, López-Gónzalez, 2013, Sanamyan et al., 2015c). It differs from Anthosactis by mesogloeal longitudinal muscles of the tentacles (they are clearly ectodermal in type species of Anthosactis). Tealidium currently includes three species, including a new species described below.

\section{Tealidium Hertwig, 1882}

Type species: Tealidium cingulatum Hertwig, 1882 , by monotypy.
Tealidium differs from Anthosactis and Hormosoma by characteristic mesogloeal papillae arranged in longitudinal rows on column. In other features it closely resembles Anthosactis: both genera have strong ectodermal longitudinal muscles on the oral sides of the tentacles and nematocyst batteries at the bases of the aboral sides of the tentacles. All stronger mesenteries are fertile.

Tealidium was created by Hertwig (1882: 51) for "all forms which agree with the Tealidae in the papillose nature of the wall, but which differ from them in the mesodermal position of the sphincter". Carlgren (1921: 191) was first who recognized the close relationship of Anthosactis and Tealidium: "outer tentacles are [...] provided with a strong battery of very long and broad nematocysts of a characteristic type, an arrangement, observed by myself only in the genera Anthosactis and Tealidium".

\section{Tealidium konoplinorum sp.n.}

Table 7; Figs 31-37.

MATERIAL EXAMINED. NW Pacific, the west Bering Sea, RV Akademik M.A. Lavrentyev, 82 cruise, ROV Comanche 18 NSCMB FEB RAS. 

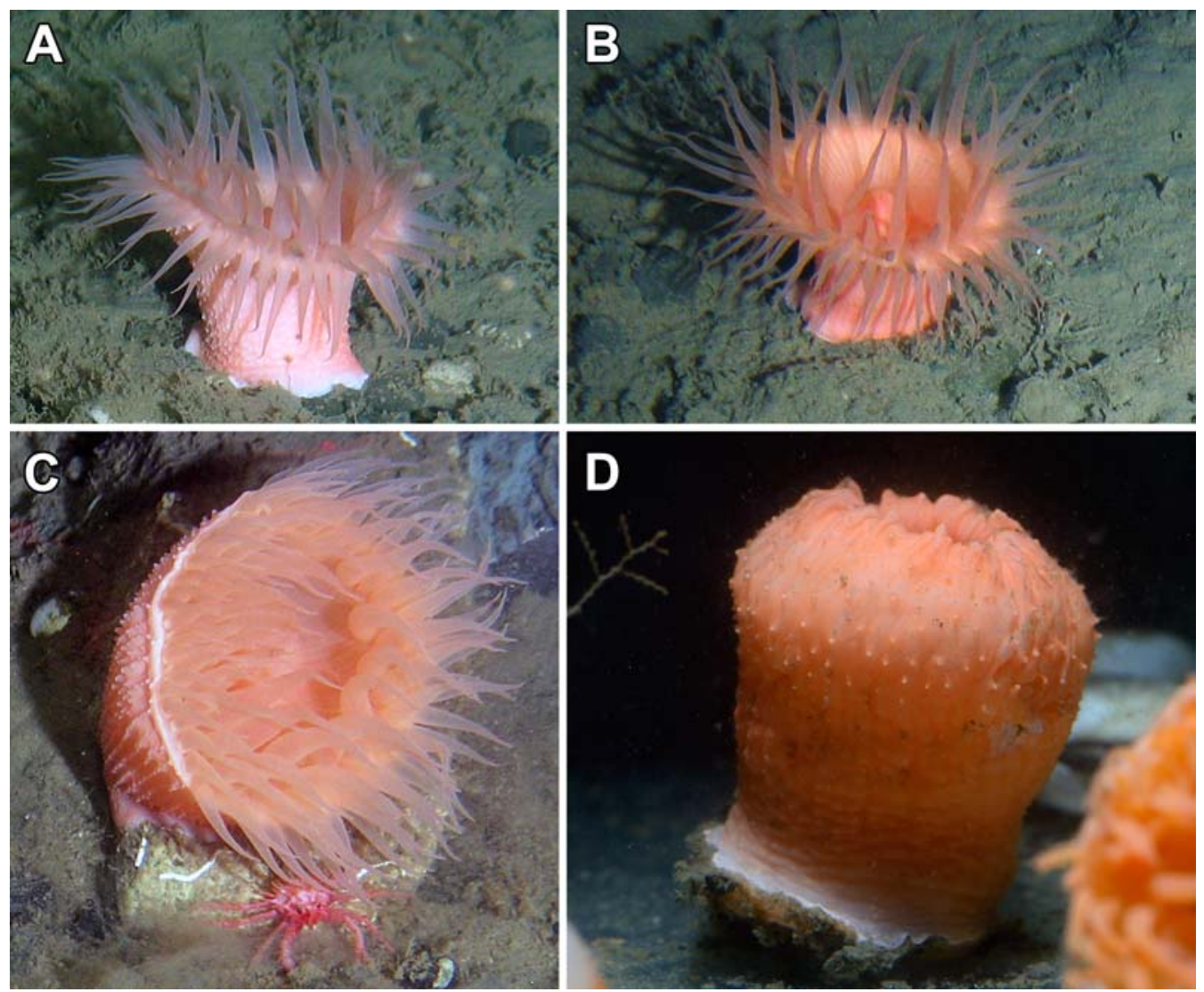

Fig. 31. Tealidium konoplinorum sp.n. A-C - specimens in natural environment $(\mathrm{C}-$ paratype MIMB 41360), photo ROV Comanche 18 NSCMB FEB RAS; D - specimen in aquarium, holotype.

Рис. 31. Tealidium konoplinorum sp.n., живые экземпляры. A-C - в естественной среде обитания (C паратип МІМВ 41360 во время сбора), фото ТНПА Comanche 18 ННЦМБ ДВО РАН; D — в аквариуме, голотип.

Holotype MIMB 41358, St. 13, sample 4, 25 June $2018,60.8333^{\circ} \mathrm{N}, 174.3739^{\circ} \mathrm{E}, 660 \mathrm{~m}$.

Paratypes: MIMB 41359, St. 13, sample 4, 25 June $2018,60.8333^{\circ} \mathrm{N}, 174.3739^{\circ} \mathrm{E}, 660 \mathrm{~m}$, one specimen; MIMB 41360, MIMB 41361, St. 18, sample 3, 30 June $2018,61.1195^{\circ}-61.1194^{\circ} \mathrm{N}$, $174.9650^{\circ}-174.9653^{\circ} \mathrm{E}, 658-662 \mathrm{~m}$, two specimens; MIMB 41362, MIMB 41363, St. 21, sample 2, 03 July $2018,60.8343^{\circ}-60.8343^{\circ} \mathrm{N}, 174.3720^{\circ}-$ $174.3726^{\circ} \mathrm{E}, 660 \mathrm{~m}$, two specimens. NW Pacific, the south-west Bering Sea, Volcanologists Massif, RV Akademik M.A. Lavrentyev, 82 cruise, ROV Comanche 18 NSCMB FEB RAS: MIMB 41364, St. 9 , sample 1, 18 June $2018,55.3451^{\circ}-55.3466^{\circ} \mathrm{N}$, $167.2750^{\circ}-167.2752^{\circ} \mathrm{E}, 1957-1933 \mathrm{~m}$, one specimen; MIMB 41365, St. 6, sample 3, 16 June 2018, $55.6826^{\circ}-55.6825^{\circ} \mathrm{N}, 167.1075^{\circ}-167.1075^{\circ} \mathrm{E}$, 3397-3393 m, one specimen.
DESCRIPTION. More than 30 specimens were photographically documented by ROV, eight of them were collected. Expanded live specimens have cylindrical column $2.5-6 \mathrm{~cm}$ in height and diameter with longitudinal rows of conical mesogloeal papillae (Fig. 31A-D). The pedal disc is $3-6 \mathrm{~cm}$ in diameter, the oral disc 5-8.5 cm, the diameter of the tentacular crown $7-15 \mathrm{~cm}$. All live specimens have monotonous orange colouration of column, tentacles, oral disc and actinopharynx which varies from bright to paler in different specimens. The limbus is white (Fig. 31A, D). The tips of columnar papillae are whitish (Fig. 31D). The aboral sides of the bases of the outer tentacles are marked by opalescent patches (Fig. 32D). Opalescent radial bands are sometimes present on the oral disc between the insertions of the mesenteries. Preserved specimens are cylindrical or the column is slightly wider in its distal (Fig. 32C) or 

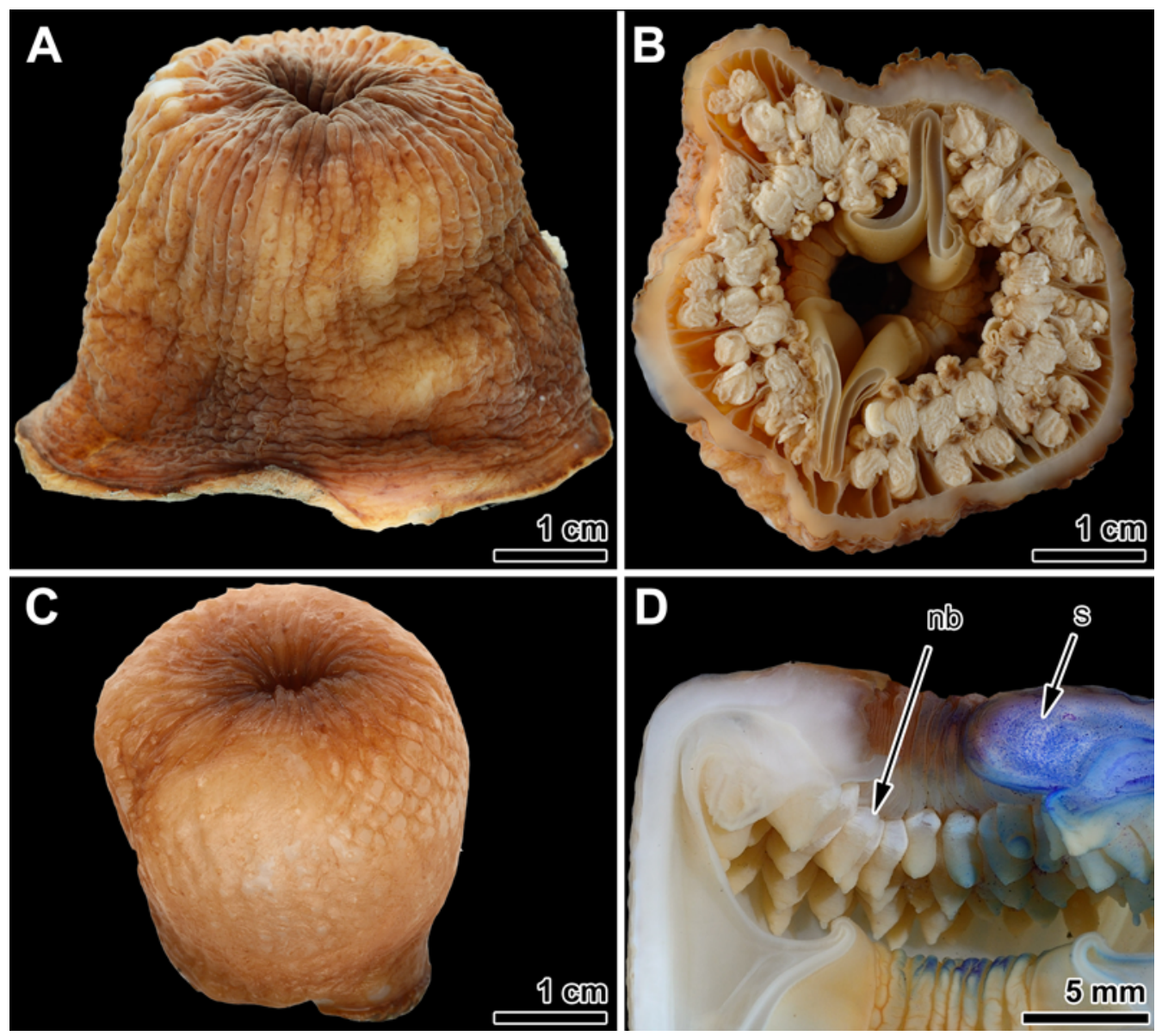

Fig. 32. Tealidium konoplinorum sp.n., preserved specimens. A — side view, paratype MIMB 41360; B transverse section of the column, paratype MIMB 41360; C - holotype; D - longitudinal section through the distal part of column, holotype.

Abbreviations: $\mathrm{nb}$ - nematocyst batteries; $\mathrm{s}$ - sphincter.

Pис. 32. Tealidium konoplinorum sp.n., фиксированные экземпляры. А - вид сбоку, паратип МІМВ 41360; В — поперечный срез колюмна, паратип MIMB 41360; C — голотип; D — продольный срез верхней части колюмна, голотип.

Сокращения: $\mathrm{nb}$ - эктодерма, содержащая батареи нематоцист; s — сфинктер.

proximal parts (when the pedal disc is expanded, Fig. 32A), $2-4 \mathrm{~cm}$ in height, $3-4.5 \mathrm{~cm}$ in diameter in the distal part and of $2.3-5.6 \mathrm{~cm}$ in diameter in the proximal part. The holotype is about $3 \mathrm{~cm}$ in height and diameter (Fig. 32C). The tentacles and the oral disc are covered by the distal part of the column. The ectoderm in preserved specimens usually is darker (brown) than all remaining parts of the anemone (which are beige), especially in the distal part of the column. Contracted columnar papillae, which retained the ectoderm, looks like dark spots (Fig. $32 \mathrm{~A})$.
The specimen MIMB 41365, recorded much deeper (3397-3393 m) than other specimens, differs in being very pale (almost without pigmentation) and having much longer columnar papillae. It is assigned to this species tentatively.

The tentacles are arranged in four or five cycles, up to $100-120$ in number, tapering to pointed tip. Inner tentacles are up to $2-4 \mathrm{~cm}$ long and $4-7 \mathrm{~mm}$ in basal diameter in expanded specimens on underwater photographs (Fig. 31A-C). The oral disc is flat, circular and wider than the column. The pedal disc is circular, slightly wider than the column, 


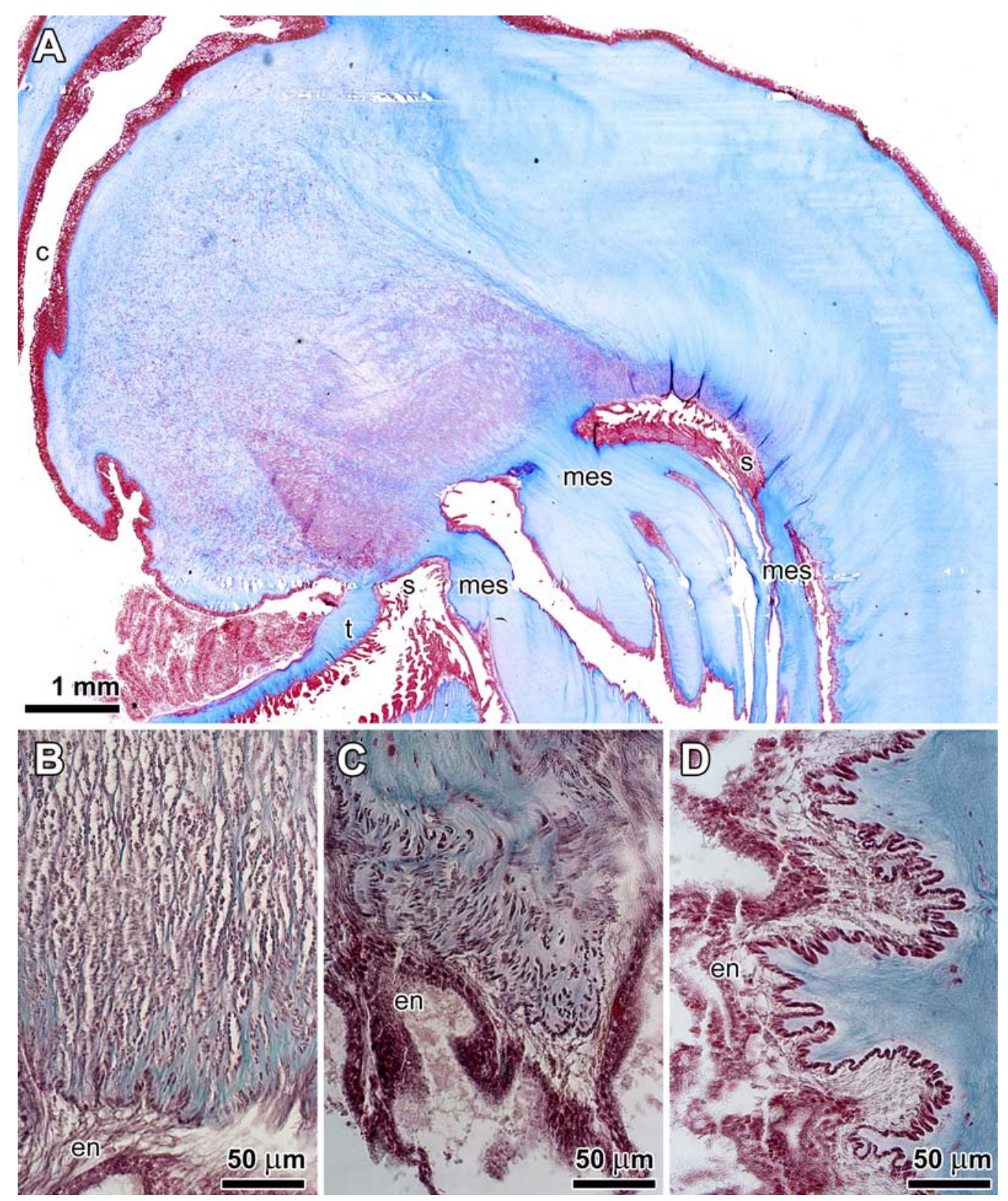

Fig. 33. Tealidium konoplinorum sp.n., paratype MIMB 41360. A - longitudinal section through the distal part of column; B - distal part of the sphincter; $\mathrm{C}$ - proximal part of the sphincter; D — circular endodermal columnar muscles.

Abbreviations: c - column; en — endoderm; mes - mesentery; $\mathrm{s}$ - sphincter (distal and proximal parts); $\mathrm{t}$ - tentacle. Рис. 33. Tealidium konoplinorum sp.n., паратип MIMB 41360. А — продольный срез через дистальную часть колюмна; В - дистальная часть сфинктера; C - проксимальная часть сфинктера; D кольцевая энтодермальная мускулатура колюмна.

Сокращения: c - колюмн; en - ентодерма; mes - мезентерий; s - сфинктер (обозначены дистальный и проксимальный концы); $\mathrm{t}$ - щупальце. 

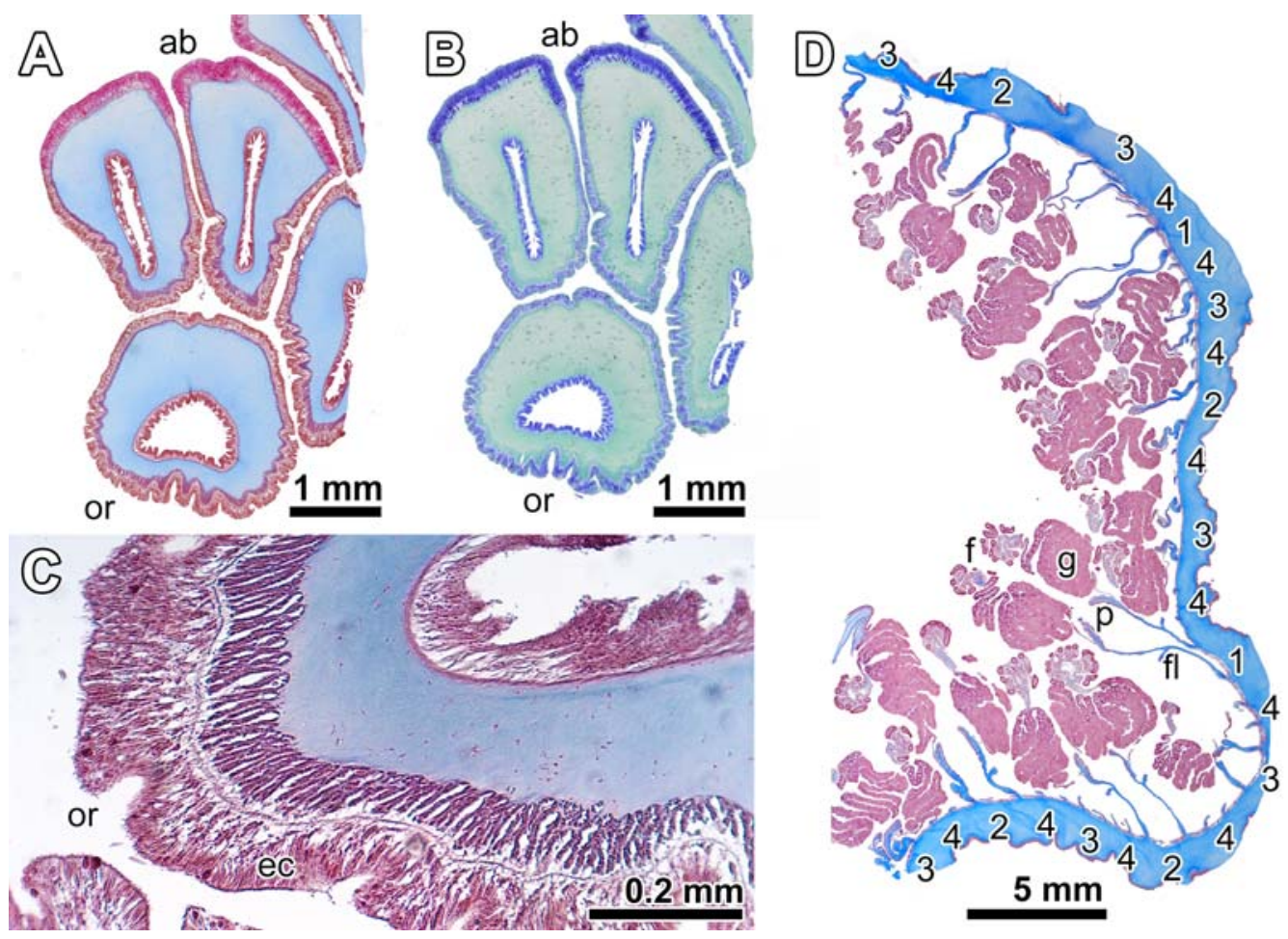

Fig. 34. Tealidium konoplinorum sp.n. A-C — specimen MIMB 41364. A - transverse section through the bases of the tentacles to show musculature and thickened ectoderm on aboral sides of outer tentacles; B transverse section through the bases of the tentacles to show nematocyst batteries (dark-coloured) on the aboral sides of the outer tentacles; $\mathrm{C}$ - longitudinal ectodermal muscles on the oral side of the tentacles; D - transverse section of the column below the actinopharynx, paratype MIMB 41360.

Abbreviations: $\mathrm{ab}$ - aboral side of the outer tentacles; ec — ectoderm; $\mathrm{f}$ - filaments; $\mathrm{fl}$ - the parieto-basilar flap; $\mathrm{g}$ - gonads; or - oral side of the tentacle; $\mathrm{p}$ - the pennon of the retractors. Numbers indicate cycle number of mesenterial pairs.

Рис. 34. Tealidium konoplinorum sp.n. А-C - экземпляр МIMВ 41364. А - поперечный срез через околобазальную часть щупалец, показывающий мускулатуру и утолщенную эктодерму на аборальных сторонах наружных щупалец; В - поперечный срез через околобазальную часть щупалец, показывающий тёмноокрашенные участки эктодермы с батареями нематоцист на аборальных сторонах наружных щупалец; C — продольная эктодермальная мускулатура щупалец на оральной стороне, увеличено; D — поперечный срез через колюмн ниже глотки, паратип MIMB 41360.

Сокращения: ab - аборальная стороне щупалец; ес - эктодерма; f - филаменты; fl — парието-базилярный вырост; g - гонады; or - оральная сторона щупалец; р - вырост ретрактора. Цифрами обозначены номера циклов мезентериальных пар.

often slightly concave in preserved specimens, with cuticle.

Marginal sphincter muscle rather strong, occupies almost the whole width of the mesogloea in the distal end of the column and forms a collar in contracted specimens (Fig. 32D, 33A). In its proximal part the sphincter extends along endodermal side of mesogloea and not separated from the endodermal circular muscles (Fig. 33C) forming an endomesogloeal complex with them. The sphincter is mostly alveolar, but may be reticular in some of its distal parts (Fig. 33B). Circular endodermal muscles are developed in a usual way in the remaining part of the column (Fig. 33D). The radial muscles of the oral disc are ectodermal. The longitudinal muscles of the tentacles are ectodermal, they are well-developed only on the oral side (Fig. 34A, C), where the mesogloea is up to three-four times thinner (150$300 \mu \mathrm{m}$ together with muscle processes) than on the aboral side $(500-800 \mu \mathrm{m})$. The endoderm of the 


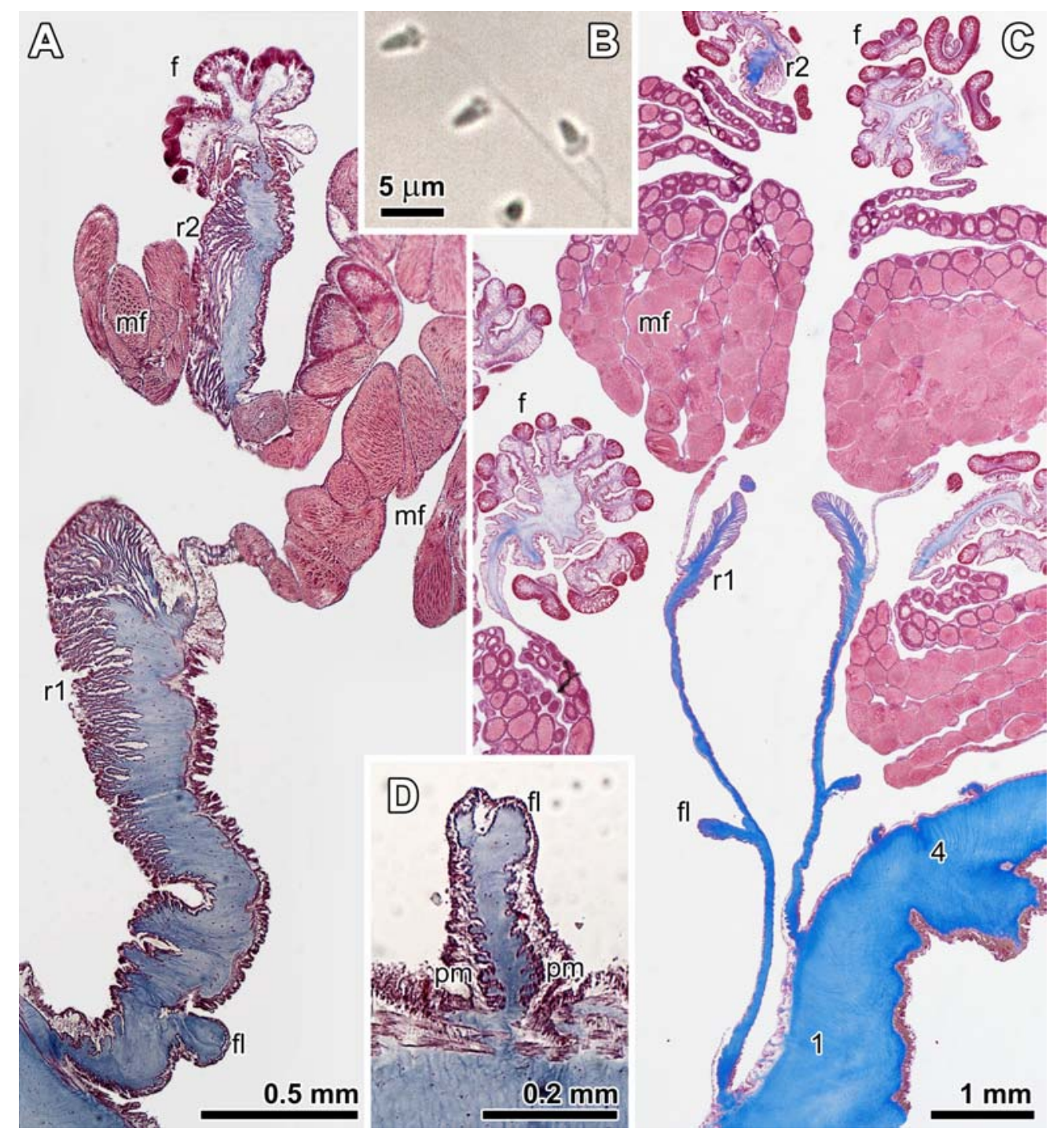

Fig. 35. Tealidium konoplinorum sp.n., paratype MIMB 41360. A - mesentery of the third cycle with two retractors; $\mathrm{B}$ - spermatozoa; $\mathrm{C}$ - transverse section of the column; D - mesentery of the last (fourth) cycle. Abbreviations: $\mathrm{f}$ - filaments; $\mathrm{fl}$ - the parieto-basilar flap; $\mathrm{mf}$ - male follicles; $\mathrm{pm}$ - parietal part of the muscles of the mesentery; $\mathrm{r} 1$ - the first retractor; $\mathrm{r} 2$ - the second retractor. Numbers indicate cycle number of mesenterial pairs. Рис. 35. Tealidium konoplinorum sp.n., паратип MIMB 41360. А - мезентерий третьего цикла, показывающий наличие двух ретракторов; В — сперматозоиды; C - поперечный срез через колюмн; $\mathrm{D}$ - мезентерий последнего, четвертого, цикла.

Сокращения: $\mathrm{f}$ - филаменты; $\mathrm{fl}$ - парието-базилярный вырост; $\mathrm{mf}$ - семенники; $\mathrm{pm}$ - париетальная часть мускулатуры мезентериев; r1 - первый ретрактор; r2 — второй ретрактор. Цифрами обозначены номера циклов мезентериальных пар.

tentacles is $50-100 \mu \mathrm{m}$ thick. The ectoderm of the tentacles is about $100 \mu \mathrm{m}$ but much thicker on the aboral side of the bases of outer (exocoelic) tentacles where it is up to $240 \mu \mathrm{m}$ and contains batteries of large nematocysts (heterotrichs) (Fig. 34B). The bases of the inner (endocoelic) tentacles contain no such batteries, the ectoderm not thickened and longitudinal musculature on their aboral sides is better developed than on aboral sides of the outer (exocoelic) tentacles. 

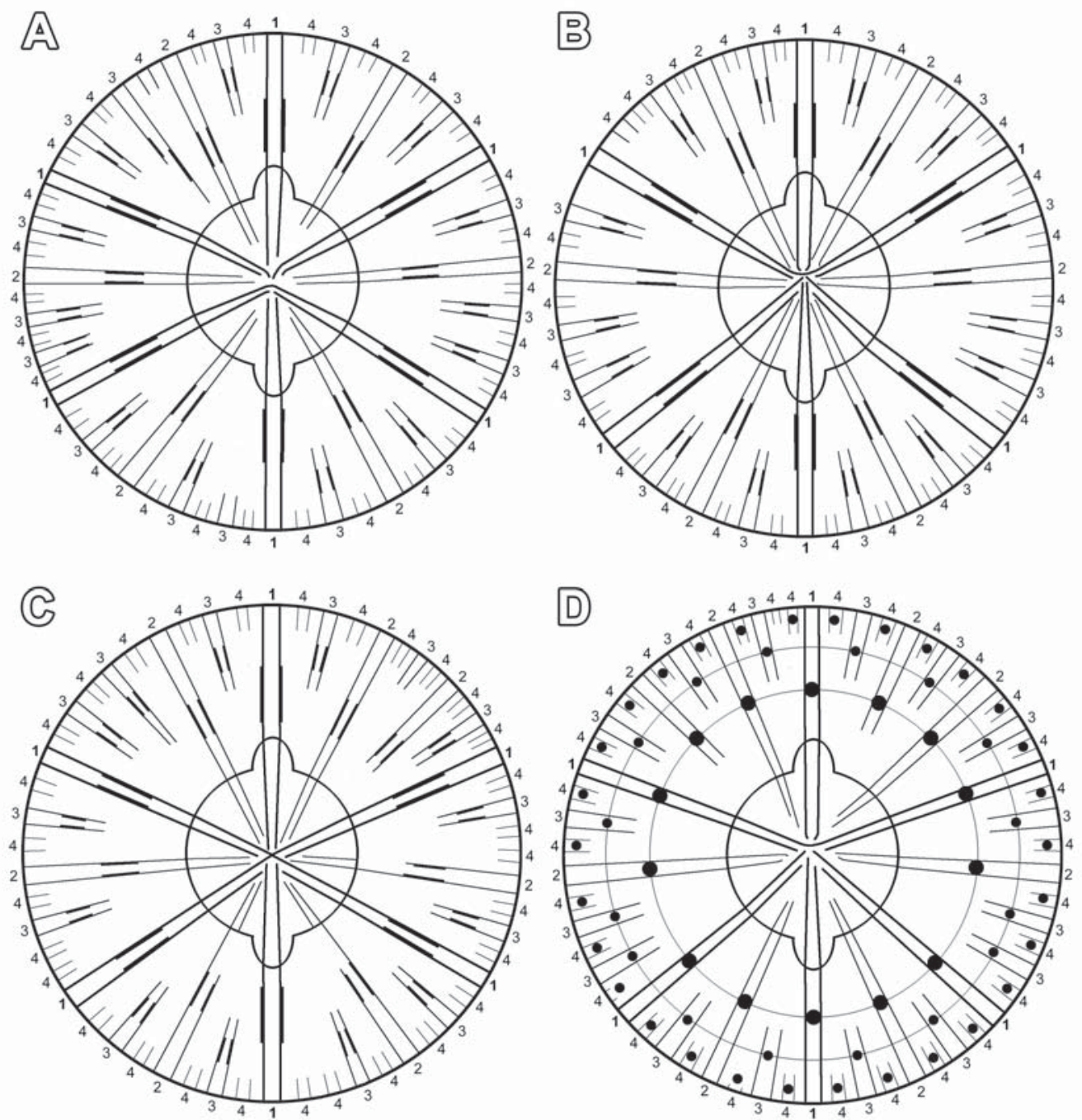

Fig. 36. Tealidium konoplinorum sp.n., arrangement of the mesenteries. A - paratype MIMB 41362; B holotype; C - paratype MIMB 41360; D - arrangement of the mesenteries and tentacles of the paratype MIMB 41363, tentacles are marked by black dots between the mesenteries, exocoelic tentacles of the last cycle not shown.

Lines in the central parts of figures show how the mesenteries run over the pedal disc. Numbers indicate cycle number of mesenterial pairs.

Pис. 36. Tealidium konoplinorum sp.n., схемы организации мезентериев. А - паратип MIMB 41362; В — голотип; C —паратип MIMB 41360; D — схема организации мезентериев и щупалец у паратипа MIMB 41363, щупальца показаны черными кружками между мезентериями, экзоцельные щупальца последнего цикла не обозначены.

В центре показан ход мезентериев на педальном диске. Цифрами обозначены номера циклов мезентериальных пар.

Actinopharynx has longitudinal ridges and two deep siphonoglyphs supported by directives (Fig. 32B).

The mesenteries are arranged hexamerously in four cycles with occasional duplications of mesente- rial pairs in second-fourth cycles. The first cycle consists of six pairs of perfect mesenteries. The second cycle may contain perfect, unequal (one mesentery reaches the actinopharynx but its partner not) and imperfect pairs. The mesenteries of the third 


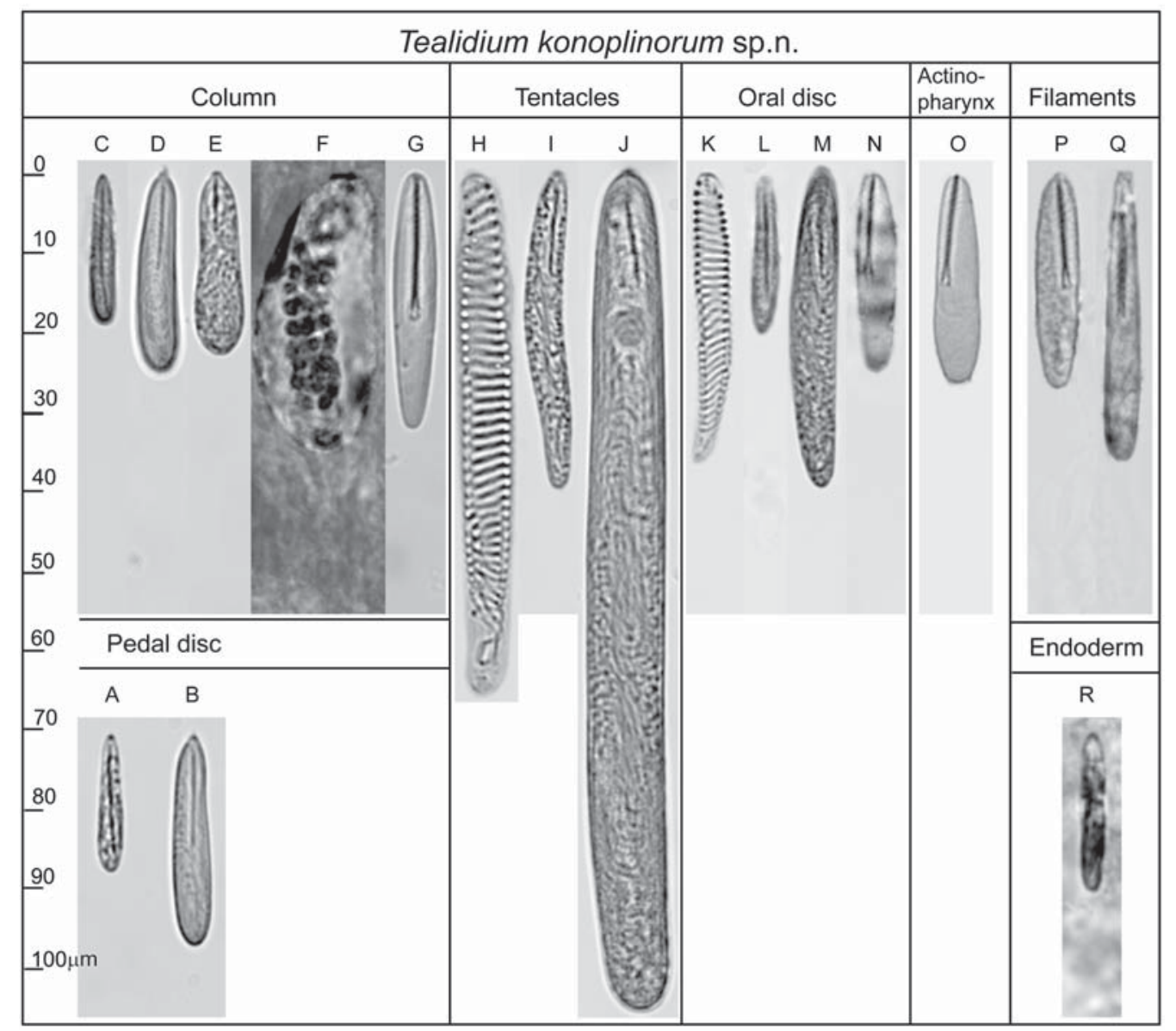

Fig. 37. Tealidium konoplinorum sp.n., distribution of cnidae (see Table 7 for size ranges).

Рис. 37. Tealidium konoplinorum sp.n., распределение книд (размеры указаны в табл. 7).

cycle are imperfect. All mesenteries of first, second and third cycles are fertile. The mesenteries of the fourth cycle are also imperfect and have no filaments, gonads and retractors, i.e. resemble microcnemes (Fig. 35D).

Retractor muscles are diffuse, well developed on the first, second and third cycles closer to adaxial side of the mesentery (near the gonads), where they often form a long flap which is longer on the first and the second cycles $(500-1000 \mu \mathrm{m}$; Figs 34D, 35C) and shorter on the third cycle $(300-600 \mu \mathrm{m}$; Fig. 35A). Parieto-basilar muscles are well-developed and have free flap up to $400 \mu \mathrm{m}$ on the first and the second cycles (Figs 34D, 35C), up to $300 \mu \mathrm{m}$ on the third cycle, and up to $90 \mu \mathrm{m}$ on many mesenteries of the fourth cycle (Fig. 35D). There are no chains of muscular meshes in the mesogloea of parietal part of the mesenteries. The parietal part of the musculature is developed on both sides of the mesentery (Fig. 35D). A weak secondary retractor is developed between the gonad and filament (a feature resembling that in Dactylanthus antarcticus (Clubb, 1908)) on all fertile mesenteries from the first to third cycles (Fig. 35A, C). The mesogloea in the region of the secondary retractor is several times thicker than in filaments. The mesogloea near the trilobate filaments not thickened in comparison with unilobate filaments. Basilar muscles well-developed.

Stomata not found.

The sexes are separate. Male follicles up to 280 $\mu \mathrm{m}$ in diameter. Spermatozoa are radially symmetric, $2.9-3.3 \times 1.2-1.7 \mu \mathrm{m}$ (Fig. 35B). Ova up to 500 $\mu \mathrm{m}$ in diameter.

Cnidom includes spirocysts, holotrichs, heterotrichs, basitrichs, $p$-mastigophores A and $p$-mastigophores B1 (Table 7, Fig. 37). All five types of the 
nematocysts reported for the column occur in the ectoderm from the limbus to the level of proximal end of the sphincter. In more distal parts of column, including the margin, only $p$-mastigophores A (Fig. $37 \mathrm{G})$ are present. The holotrichs in the ectoderm of column (Fig. 37F; 24 cnidae measured) were detected in two specimens (among three examined): on 10 $\mu \mathrm{m}$ histological sections in one paratype MIMB 41360 and on squash samples of ectoderm of column in specimen MIMB 41364. Groups of basitrichs (Fig. 37D) were detected in papillae. Very large heterotrichs (Fig. 37J) are present only at the distance of $0.8-1 \mathrm{~mm}$ from the bases of the aboral side of the outer (exocoelic) tentacles in the patches of the thickened ectoderm where they form a battery. All heterotrichs, basitrichs and $p$-mastigophores B1 are stained by basic dyes (toluidine blue) in contrast with spirocysts and $p$-mastigophores A. Trilobate filaments contain one type of rather numerous nematocysts, $p$-mastigophores $\mathrm{A}$, of the same size range as in unilobate filaments (Fig. 37P).

HABITAT. The species was recorded at bathyal depths attached to stones or in muddy places on firm bottom consisting of mixture of small stones and gravel. Most often the specimens were recorded on the methane seeps $(658-662 \mathrm{~m})$ near or directly on bacterial mats together with bivalves of the genera Calyptogena, Acharax and Pecten (see Krylova et al., 2019; Galkin et al., 2019). Outside the sites of methane seeps they are very rare, only two specimens were recorded in other locations on greater depths (1933-1957 $\mathrm{m}$ and 3393-3397 $\mathrm{m}$ ). Thus, the species is not an obligate member of seep-associated communities but often occurs there.

ETYMOLOGY. The species is named after Alexander and Nikita Konoplin, specialists of the team of the ROV Comanche 18 NSCMB FEB RAS.

REMARKS. Only two species of Tealidium were known previously, both from very old original descriptions (Hertwig, 1882 and Carlgren, 1921).

Tealidium cingulatum Hertwig, 1882 is based on one specimen collected by Challenger Expedition in subantarctic waters (between Australia and Antarctic continent, $50^{\circ} 1^{\prime} \mathrm{S}, 123^{\circ} 4^{\prime} \mathrm{E}$ ) at 1800 fathoms (=3276 m). The specimen was small, strongly contracted and flattened (a few $\mathrm{mm}$ in height, the pedal disc, attached to stone, $1 \mathrm{~cm}$ in diameter). Nevertheless, Hertwig (1882) was able to provide important anatomical details, in particular he described a very strong mesogloeal sphincter and stated that the longitudinal tentacle muscles are ectodermal. He was not able to count tentacles but concluded that the specimen has probably only 12 pairs of mesenteries arranged in two cycles.
Tealidium jungerseni Carlgren, 1921 is based on four specimens from North Atlantic: $64^{\circ} 34^{\prime} \mathrm{N}$, $31^{\circ} 12^{\prime} \mathrm{W}, 1300$ fathoms (=2366 m) and $59^{\circ} 12^{\prime} \mathrm{N}$, $51^{\circ} 05^{\prime} \mathrm{W}, 1870$ fathoms $(=3403 \mathrm{~m})$. All specimens were strongly contracted, disc-shaped. Carlgren (1921) pointed that the nematocysts in the batteries of his species, are much larger than in the Anthosactis. Size range he reported, 106-134 $\mu \mathrm{m}$, is similar to the size range reported here for $T$. konoplinorum sp.n. His specimens, however, differs significantly in the shape and have 48 tentacles, i.e. much fever than in the present species, they cannot be conspecific. Riemann-Zürneck (1997: 491) examined one specimen of this species described by Carlgren (1921), which should be considered syntype, but stated that "this tiny, strongly contracted animal (about $1 \mathrm{~cm}$ diameter and $3 \mathrm{~mm}$ high) showed neither the bulging sphincter nor the large tentacle nematocysts. Hence, the taxonomic relations of the genera Anthosactis and Tealidium remain uncertain". A discovery of T. konoplinorum sp.n., which has all characters of Tealidium, as they are described by Carlgren (1921), including very clear mesogloeal papillae on column and nematocyst batteries (visible by naked eye) with nematocysts of the same type and same size range as reported by Carlgren (1921), allowed us to clarify its affinity: it indeed is closely related with Anthosactis in full accordance with the initial conclusion of Carlgren (1921).

\section{Family Tetracoelactinidae fam.n.}

DIAGNOSIS. Actiniaria with definite base and mesogloeal sphincter which is not separated from circular endodermal musculature of column. Acontia not present. The tentacles arranged peculiarly in connection with the bilateral development of the younger mesenteries. After the stage with six pairs of mesenteries the later mesenteries arise bilaterally in four sectors of the animal, so that the youngest mesenteries appear in the middle of the four primary exocoels in which in each pair of the younger mesenteries one mesentery is larger than its partner. Mesenteries differentiated into perfect sterile mesenteries which have filaments and imperfect fertile mesenteries without filaments. Cnidom: spirocysts, basitrichs, $p$-mastigophores A and p-mastigophores B1.

Type genus: Tetracoelactis Sanamyan et Sanamyan, 2019.

Diagnosis of the family Exocoelactinidae Carlgren, 1925 is reverted to the diagnosis published by Carlgren (1949) due to removing the genus Tetracoelactis from Exocoelactinidae. Tetracoelactinidae fam.n. differs principally from Exocoelactinidae in the following features. 


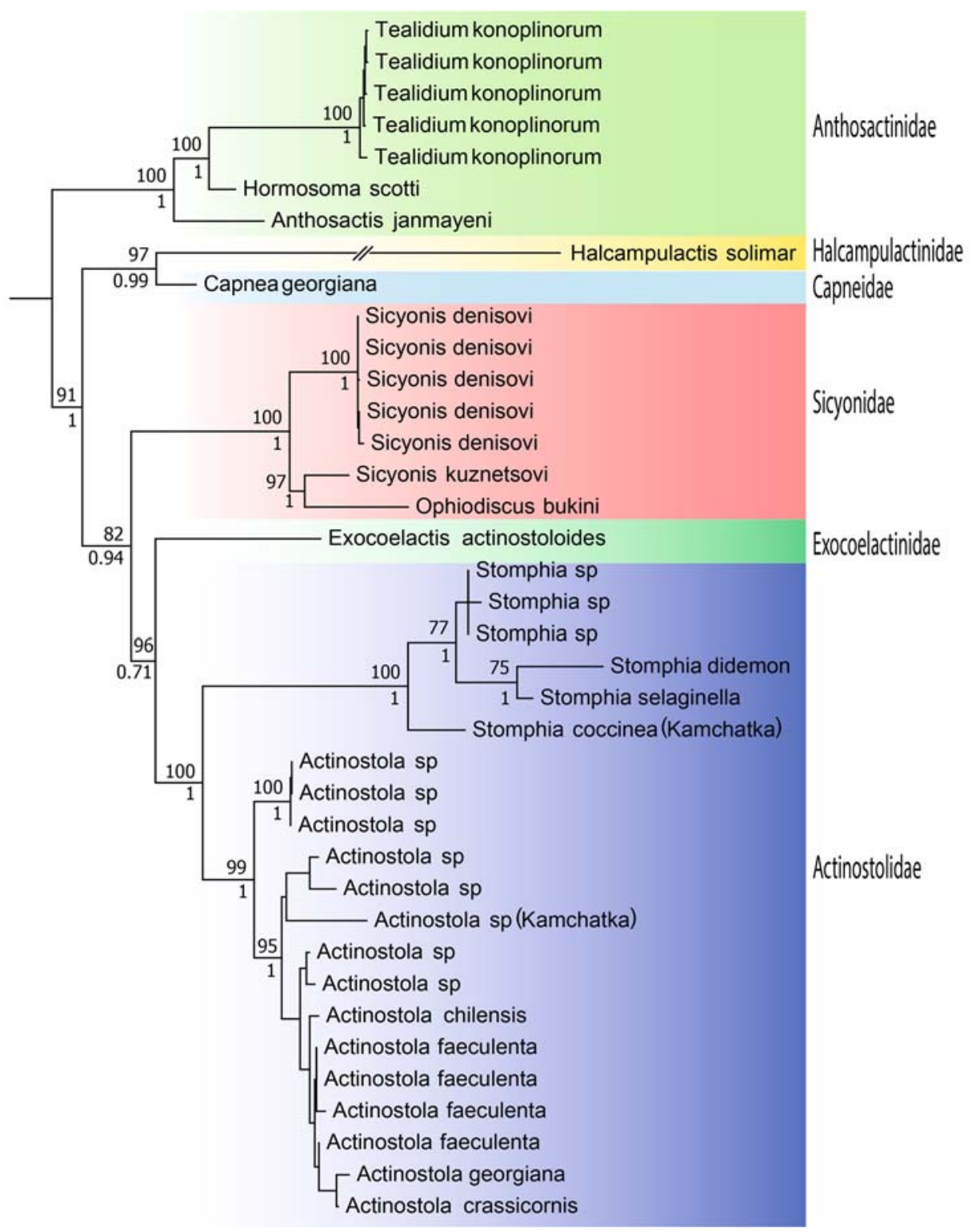

Fig. 38. Phylogenetic relationships based on $12 \mathrm{~S}+16 \mathrm{~S}+18 \mathrm{~S}+28 \mathrm{~S}+$ COIII concatenated dataset inferred by Bayesian inference (BI). Numbers above branches indicate bootstrap values for Maximum Likelihood (ML); numbers below branches represent posterior probabilities from BI. Only a sub-tree containing relevant taxa is shown. For full phylogenetic trees generated during the present study see Supplement Fig. 1 (ML tree) and Supplement Fig. 2 (BI tree).

Рис. 38. Филогенетическое дерево, основанное на объединенном наборе сиквенсов $12 \mathrm{~S}+16 \mathrm{~S}+18 \mathrm{~S}$ $+28 \mathrm{~S}+$ COIII представленное Байесовой вероятностью (BI). Числа над ветвями показывают бутстеп значения для ML дерева; числа под ветвями показывают апостериорные вероятности для BI дерева. Показана только часть дерева с релевантными таксонами. Полные деревья см. в приложении (рис. 1 ML дерево и рис. 2 - BI дерево). 
In Tetracoelactinidae fam.n. the bilateral arrangement of the mesenteries appears after the first cycle and not in all primary exocoels (Tetracoelactis has only four meristematic zones where bilaterally arranged mesenterial pairs are formed) and thus a bilateral symmetry of the whole specimen is formed. In Exocoelactinidae the bilateral arrangement of the mesenteries is formed only after the second cycle in all secondary exocoels (12 meristematic zones), so that the specimen retains radial hexamerous symmetry. Moreover, in Tetracoelactis the imperfect mesenteries lack filaments but have gonads, while the perfect mesenteries have filaments but lack gonads. In contrast, in Exocoelactinidae the gonads and filaments are present on the same mesenteries. These families have similar cnidom but Tetracoelactis has no spirocysts in column which are present in column of Exocoelactis actinostoloides (Wassilieff, 1908).

The features which distinguish Tetracoelactis from the members of the family Exocoelactinidae suggest a relation with Sicyonidae: the bilateral symmetry of the polyp, the absence of the filaments in imperfect fertile mesenteries, the presence of the usual radial and the bilateral arrangement of the mesenteries in different primary exocoels. The distribution of the cnidae (the absence of the spirocysts on most part of the column) also is more similar to Sicyonis. These features suggest that Tetracoelactis attains a special position in the order Actiniaria, it cannot be assigned neither to Exocoelactinidae, nor to Sicyonidae and should be placed to its own family.

\section{Discussion}

The arrangement of the mesenteries in Sicyonis has been described in details only by Carlgren (1921, 1928a) and Doumenc (1975) who gave the diagram of the distribution of the mesenteries in the species they studied. More recent authors failed to describe the arrangement of the mesenteries or simply stated that it is "irregular" (e.g. Eash-Loucks, Fautin, 2012). In general, the arrangement of the mesenteries in Sicyonis spp. is bilaterally symmetric in relation to a directive plane. This symmetry is expressed in the fact that two primary exocoels, located on two sides of a directive pair conditionally called "dorsal", often contain one pair of the mesenteries of the second cycle, while two lateral and two "ventral" primary exocoels have two pairs of the mesenteries of the second cycle (in each exocoel, Fig. 39). Duplication of these and subsequent pairs indicates that they appear bilaterally, as in exocoelactids. This arrangement resembles recently described Tetracoelactis ioran (see Sanamyan, Sanamyan, 2019, Fig. 3), in which two "dorsal" primary exocoels have the usual arrangement the mesenteries, while in lateral and "ventral" primary exocoels the arrangement is bilateral. In Sicyonis, however, the duplication of the mesenterial pairs, characteristic for bilateral arrangement of the mesenteries, is mixed with the usual mode of the appearance of new mesenterial pairs between the pairs of preceding cycles. Moreover, in described in the present paper species we observed duplications of the mesenterial pairs of the second cycle also in "dorsal" primary exocoels, such duplications occur in $S$. denisovi sp.n., S. titanic sp.n. and in one specimen of $S$. ingolfi (Fig. 19B). The unequal pairs (one mesentery perfect, another not), characteristic for the bilateral mode of the appearance of new mesenteries, may occur in Sicyonis in all primary exocoels, including the "dorsal" ones. Different species of Sicyonis have different combinations of these two modes of the development of mesenteries and the family Sicyonidae may represent a transition in the arrangement of the mesenteries between Exocoelactinidae and, especially, Tetracoelactinidae fam.n. and Actinostolidae, which also often have duplications in the second and third cycles and have unequally developed mesenteries in younger cycles according to Actinostola-rule.

Duplication of the mesenterial pairs allows for a faster increase the number of the mesenteries and the size of the anemone. In Tetracoelactis the "dorsal" primary exocoels, where the mesenteries appear in a usual way, have three cycles of the mesenteries, while the lateral and "ventral" primary exocoels with bilateral arrangement have up to five cycles of the mesenteries in the same specimen (Sanamyan, Sanamyan, 2019). The serial appearance of the mesenterial pairs in one direction from one side of the exocoel, as in Rugosa (in four primary exocoels, two lateral and two ventral) and in zoantharians (in two ventral exocoels), is not so effective for increasing the size of the polyps. In Sicyonis two most rapid modes of appearance of new mesenteries, bilateral and multiplication, 

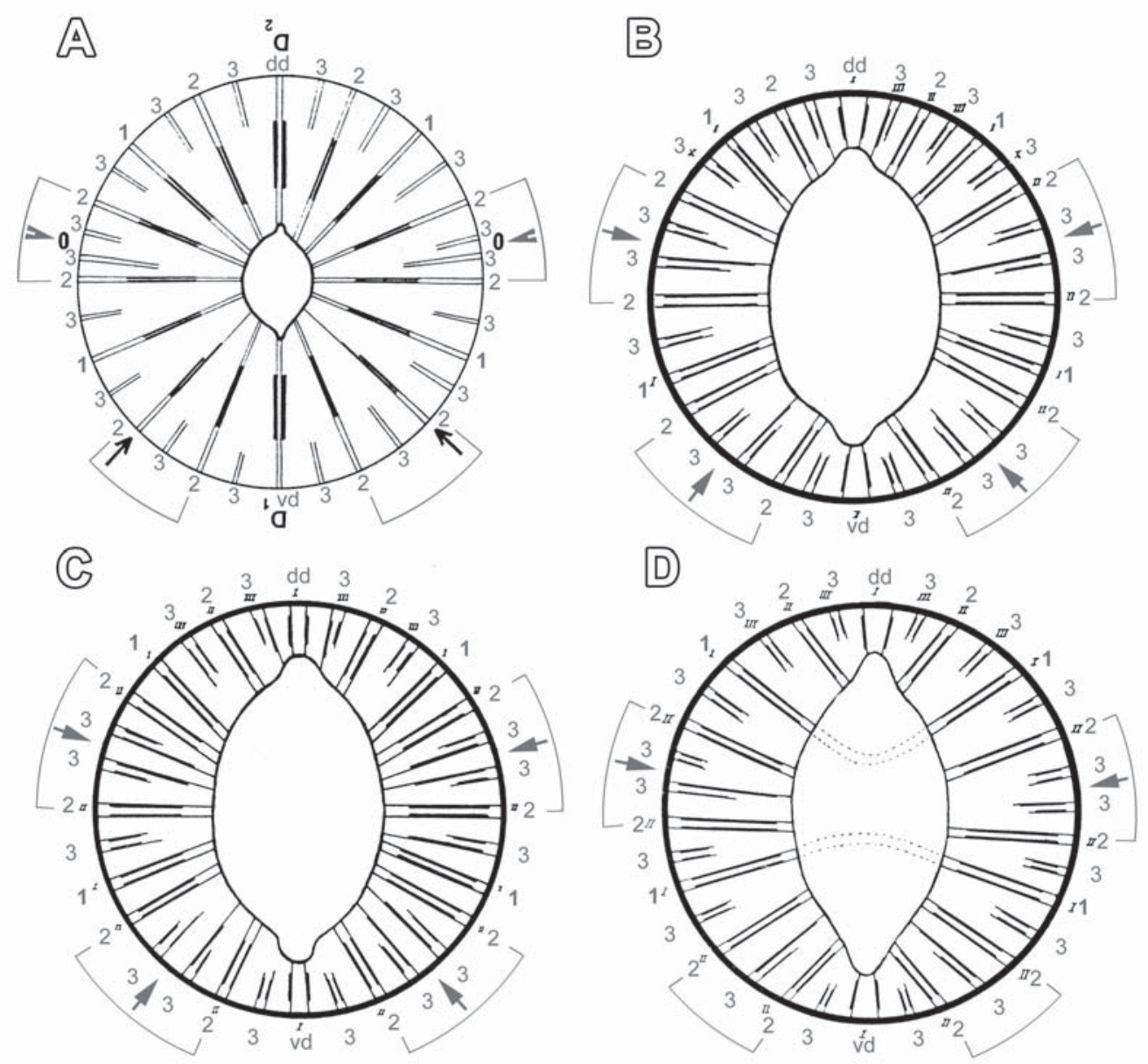

Fig. 39. Arrangement of the mesenteries in Sicyonis. A - Sicyonis tuberculata (after Doumenc, 1975, Fig. 7); B - Sicyonis tuberculata (after Carlgren, 1921, Fig. 202A); C - Sicyonis tuberculata (after Carlgren, 1921, Fig. 202B); D - Sicyonis ingolfi (after Carlgren, 1921, Fig. 203).

All figures are turned with "dorsal" directives up. Our markings in the original drawings are gray ("dd" and "vd" — dorsal and ventral directives; gray numbers (Arabic) indicate cycle number of mesenterial pairs; gray brackets show zones where mesenterial pairs of the second cycle are duplicated; gray arrows point to the zones of duplication of the mesenterial pairs of the third cycle).

Рис. 39. Схемы организации мезентериев в видах рода Sicyonis. A - Sicyonis tuberculata (по Doumenc, 1975, рис. 7); В - Sicyonis tuberculata (по Carlgren, 1921, рис. 202A); C - Sicyonis tuberculata (по Carlgren, 1921, рис. 202B); D - Sicyonis ingolfi (по Carlgren, 1921, рис. 203).

Все рисунки повернуты “дорсальными” направляющими парами мезентериев вверх. Наши обозначения на оригинальных рисунках выполнены серым цветом (“dd" и "vd” — “дорсальные” и "вентральные” направляющие; серыми цифрами (арабскими) обозначены номера циклов мезентериальных пар; серые скобки показывают зоны удвоения мезентериальных пар второго цикла, серые стрелки указывают на места удвоения мезентериальных пар третьего цикла).

are combined. The ability to grow fast is important for them because the species of the genus Sicyonis become fertile only after full formation of all strong sterile (with few exceptions) mesenteries.
Marginal sphincter adjoining the endoderm and combined with the endodermal circular muscles into endomesogloeal complex (which may be termed endomesogloeal sphincter) is characteristic for Exocoelactinidae, Tetracoelac- 
tinidae fam.n., Sicyonidae, Anthosactinidae fam.n. and Actinostolidae. It differs from the sphincter of other Actiniaria in which mesogloeal sphincter is separated from the endoderm by a layer of mesogloea such as Hormathiidae, Amphianthidae, Kadosactinidae, Actinoscyphiidae, Halcampidae, Metridiidae, Sagartiidae etc. Complete separation of marginal sphincter muscle from endodermal circular columnar muscles of column is, probably, evolutionary more advanced feature. The sphincter adjoining the endoderm may indicate some relationship with the families having endodermal sphincter. Actually, in some Actiniidae, e.g. in Cribrinopsis and Urticina, the muscle processes in the sphincter often anastomose and form patches with reticular structure (see Sanamyan, Sanamyan, 2006; Sanamyan et al., 2020) and in such species as Isosicyonis alba (Studer, 1879) the sphincter is meso-endodermal to "chiefly mesogloeal" (see Carlgren, 1949; Sanamyan et al., $2015 \mathrm{c}$ ). Some of them have noticeable bilateral trend in the arrangement of the mesenteries, e.g. Cribrinopsis fernaldi Siebert et Spaulding, 1976 (see Sanamyan et al., 2019), in which some mesenterial pairs are duplicated and there are differences in the arrangement of the mesenteries in two "dorsal" primary exocoels and four remaining primary exocoels. Radial symmetry of coral polyps developed probably in a result of attached live style of initially bilaterally symmetric ancestor (Malakhov, 2004; 2016). The existence additional traits of bilateral symmetry in the arrangement of the mesenteries and tentacles in discussed groups of Actiniaria may be considered as a plesiomorphy which is better expressed only in Edwardsiidae, where bilateral symmetry appears in the first cycle of mesenteries and often in the presence of single siphonoglyph.

Another feature common for families having endodermal and endomesogloeal sphincter is the absence of $p$-mastigophores B2. These cnidae are present in the families having mesogloeal sphincter separated from the endoderm. Schmidt (1974) considered the presence of $p$ mastigophores B (= $p$-rhabdoids $\mathrm{B})$, which have three-lobed apical flap, being more ancient feature, while the presence of thin-walled $p$-mastigophores A (= $p$-rhabdoids A) without such flap more advanced and basing on these features subdivided mesomyarian Actiniaria (with and without acontia) on early Mesomyaria (without $p$-rhabdoids A) and later Mesomyaria (with $p$ rhabdoids A), while Endomyaria, according to him, is most evolutionary advanced group. However, nematocysts with three-lobed flap do not occur in other orders of Anthozoa and are synapomorphy for Actiniaria (see Rodríguez et al., 2014; Xiao et al., 2019), while nematocysts without three-lobed flap are present in all groups of corals and are symplesiomorphy. Spirocysts (also thin-walled and without flap) occur in all Hexacorallia (see Bozhenova et al., 1988). In basal (according to the molecular data, e.g. Rodríguez et al., 2014) groups, such as Relicanthidae, Edwardsiidae, Halcuriidae, Actinernidae, $p$-mastigophores B not present, they have only $p$-mastigophores A. In Stomphia (Actinostolidae), Hormosoma (Anthosactinidae fam.n.) and in many Actiniidae and related families $p$-mastigophores B also not occur, only $p$-mastigophores A are present. The families in which marginal mesogloeal sphincter is separated from the circular endodermal columnar muscles (listed above) are characterized by the presence $p$-mastigophores B and, in addition, in some genera and families $p$-mastigophores $\mathrm{A}$ may also occur. In classification of $p$-mastigophores we should not mix an evolution of thinwalled flap-less $p$-mastigophores A and $p$-mastigophores B with thick-walled capsules and three-lobed apical flap because they derived from different ancestor forms of cnidae and are only distantly related with each other: $p$-mastigophores $\mathrm{A}$ are closer to spirocysts than to $p$ mastigophores $\mathrm{B}$, while $p$-mastigophores $\mathrm{B}$ are closer to basitrichs.

First nematocysts with three-lobed apical flap were, probably, small holotrichs resembling holotrichs in Dactylanthus antarcticus (see Sanamyan et al., 2015c). Small basitrichs are possibly appeared in a result of the elongation of the spines in proximal part of the tubule. They were similar to small basitrichs in Dactylanthus antarcticus (it seems that this species, as well as Preactis England in England, Robson, 1984, retains many archaic traits, e.g. the longitudinal ectodermal muscles of column, the presence of tentacle-like vesicles on column with 
nematocysts composition similar to that in the tentacles, only unilobate filaments, double retractors in the region of gonads, symmetrical round-headed spermatozoa resembling those of Corallimorphus and Peachia). Next differentiation was the formation of the thickening of the basal part of the tubule (the "shaft") and appearance of mastigophores B1. Several transitional forms from basitrichs to mastigophores are represented by nematocysts in filaments of some Actiniidae (e.g. Anthopleura, Aulactinia, Bunodosoma, Epiactis, Cribrinopsis, Urticina). Different authors name them either as basitrichs, or microbasic $b$-mastigophores, or $p$-mastigophores (see discussion in Sanamyan et al., 2015a). The difference between the thickness of the basal, more strongly armed part of the tubule, from its more distal part varies significantly in different species of these genera. For example, in Aulactinia the difference between the thickness of the shaft and terminal tubule is small (the shaft is thicker than the tubule about 1.5 times in Aulactinia vancouverensis Sanamyan et al., 2013) or, sometimes, they are of the same diameter (as in Aulactinia vladimiri Sanamyan et al., 2015 or Aulactinia incubans Dunn et al., 1980); in Urticina clandestina Sanamyan et al., 2013 the shaft and the terminal tubule are of the same diameter while in $U$. grebelnyi Sanamyan et Sanamyan, 2006 the shaft is at least two times thicker than the tubule, and about the same difference is in Bunodosoma biscayensis Fischer, 1874 (see den Hartog, 1987: 545, Fig. 10e). Moreover, V-shaped notch in unfired capsule also may be poorly defined in these cnidae or the tip of the shaft may appear pointed in some perspectives (sometimes when the capsule is rotated its tip may change appearance from pointed to spitted). In Sicyonis $p$ mastigophores B1 also sometimes have pointed tip in unfired capsule. In S. kuznetsovi sp.n. this nematocyst is relatively narrow and has poorly defined shaft, that again resembles transitional form between basitrichs and $p$-mastigophores B1. The whole series of nematocysts, holotrichs - basitrichs $-p$-mastigophores $\mathrm{B} 1$, have affinity to basic stains (they are stained, for example, by toluidine blue or safranin) probably because of their acid content. The same feature have drop-shaped $p$-mastigophores $\mathrm{B} 1$, as, for example, in Artemidactis victrix Stephenson, 1918 (see Sanamyan et al., 2015c) in Sagartiidae. Further elongation and differentiation of the shaft led to appearance of $p$-mastigophores B2, which are not stained by basic stains (it is possible that in some species $p$-mastigophores B1 may be stained in different degree or even sometimes not stained at all).

$P$-mastigophores B2 are most diverse in Sagartiidae and related families. The shaft of these nematocysts undergone further differentiation into a "Faltstück", a basal part with weak armature, and a distal part with large spines. In $p$-mastigophores B2 the Faltstück may be almost not defined or be short - Carlgren (1949) assigned them to microbasics while England (1991) defined among them also mesobasics with short Faltstück. $P$-mastigophores B2 with long Faltstück were termed macrobasic $(=p$ mastigophores B2b). Schmidt (1974) assigned members of this group to late Mesomyaria, i.e. to evolutionary more advanced forms, because they have thin-walled $p$-mastigophores A, but in this group we see maximal diversity and complexity of $p$-mastigophores $\mathrm{B}-\mathrm{a}$ result of evolution of thick-walled cnidae with threelobed apical flap. Thus, they indeed may be most recently evolved group in evolution of Actiniaria, while Actinostolidae (also assigned by Schmidt, 1974 to late Mesomyaria), Sicyonidae, Tetracoelactinidae fam.n., Anthosactinidae fam.n., Exocoelactinidae, together with Actiniidae, are evolutionary earlier group in relation to Sagartiidae, Hormathiidae and other families of this group (listed above). This hypothesis is also supported by the presence in the former families such features as mesogloeal sphincter confined to endodermal circular muscles, often occurrence of bilateral symmetry in the arrangement of the mesenteries, occurrence of double retractors which were described in the present work in Tealidium konoplinorum sp.n. and earlier in Preactiniidae (see Carlgren, 1911; England, Robson, 1984; Sanamyan et al., 2015c).

\section{Compliance with ethical standards}

CONFLICTS OF INTEREST: The authors declare that they have no conflicts of interest.

Supplementary data. The following materials are available online. 
Supplement Table 1. List of taxa and sequences used for phylogenetic analysis. Sequences generated during the present study are in bold.

Supplement Fig. 1. ML phylogenetic tree based on concentrated datasheet, see text for details. Numbers indicate bootstrap values for Maximum Likelihood.

Supplement Fig. 2. Phylogenetic tree represented by Bayesian Inference. Numbers represent posterior probabilities (x100).

Acknowledgments. Authors thank Captains Y.N. Gorbach and V.B. Ptushkin and the crew of the RV Akademik Mstislav Keldysh and RV Akademik M.A. Lavrentyev, as well as the pilots and technicians of the ROV Comanche 18, for highly professional work. Warm acknowledgements concern the Laboratory of Molecular Genetics at Russian Federal Research Institute of Fisheries and Oceanography (VNIRO). We are grateful to two referees for their constructive comments. The research was funded by the Ministry of Science and Higher Education, Russian Federation (grant 13.1902.21.0012, contract No 075-15-2020-796). The molecular analysis was conducted by E.S. Bocharova under the IDB RAS Government basic research program in 2021 No. 0088-2021-0009.

\section{References}

Andres A. 1884. Le Attinie (Monografia). Leipzig: Verlag von Wilhelm Engelmann. 459 p.

Arellano S.M., Fautin D.G. 2001. Redescription and range extension of the sea anemone Exocoelactis actinostoloides (Wassilieff, 1908), with revision of genus Exocoelactis (Cnidaria, Anthozoa, Actiniaria) // Zoosystema. Vol.23. P.645-657.

Bocharova E. 2015. Reproductive biology and genetic diversity of the sea anemone Aulactinia stella (Verrill, 1864) // Hydrobiologia. Vol.759. P.27-38.

Bozhenova O.V., Grebelnyi S.D., Stepanjants S.D. 1988. [The possible ways of the Cnidaria nematocysts evolution] // O.A. Scarlato (ed.). Gubki i knidarii. Sovremennoe sostoyanie i perspektivy issledovaniy. Leningrad: Zoological Institute. P.57-74 [in Russian].

Bourne G.C. 1900. The Anthozoa // E.R. Lankester (ed.). Treatise on Zoology. Part II. The Porifera and Coelenterata. London: Adam \& Charles Black. P.1-84.

Carlgren O. 1893. Studien über nordische Actinien // Kungliga Svenska Vetenskapsakademiens Handlingar Bd.25. S.1-148.

Carlgren O. 1911. Über Dactylanthus (Cystiactis) antarcticus (Clubb) zugleich ein Beitrag zur Phylogenie der Actiniarien // Wissenschaftliche Ergebnisse der Schwedischen Südpolarexpedition, 1901-1903. Bd.6. Nr.5. S.1-31.
Carlgren O. 1921. Actiniaria. Part $1 / /$ The Danish IngolfExpedition. Vol.5. No.1. P.1-241.

Carlgren O. 1928a. Actiniaria der Deutschen TiefseeExpedition // Wissenschaftliche Ergebnisse der Deutschen Tiefsee-Expedition auf dem Dampfer „Valdivia“ 1898-1899. Bd.22. S.125-266.

Carlgren O. 1928b. Ceriantharier, Zoantharier och Actiniarier // Meddelelser om Grønland. Bd.23. S.253-308.

Carlgren O. 1932. Die Ceriantharien, Zoantharien und Actiniarien des arktischen Gebietes // F. Römer, F. Schaudinn, A. Brauer, W. Arndt (Hrsg.). Eine Zusammenstellung der arktischen Tierformen mit besonderer Berücksichtigung des Spitzbergen-Gebietes auf Grund der Ergebnisse der Deutschen Expedition in das Nördliche Eismeer im Jahre 1898. Jena: Gustav Fischer. S.255-266.

Carlgren O. 1934. Ceriantharia, Zoantharia and Actiniaria from the "Michael Sars" North Atlantic Deep-sea Expedition 1910 // Report on the Scientific Results of the "Michael Sars" North Atlantic Deep-Sea Expedition. Vol.5. P.1-27.

Carlgren O. 1949. A survey of the Ptychodactiaria, Corallimorpharia and Actiniaria // Kungliga Svenska Vetenskapsakademien Handlingar. Bd.1. P.1-129.

Doumenc D.A. 1975. Actinies bathyales et abyssales de l'océan Atlantique nord familles des Hormathiidae (genres Paracalliactis et Phelliactis) et des Actinostolidae (genres Actinoscyphia et Sicyonis) // Bulletin du Muséum National d'Histoire Naturelle (Paris). Vol.197. P.157-204.

Dunn D.F. 1983. Some Antarctic and sub-Antarctic sea anemones (Coelenterata: Ptychodactiaria and Actiniaria) // Antarctic Research Series. Vol.39. P.1-67.

Dunn D.F., Chia F.S., Levine R. 1980. Nomenclature of Aulactinia (= Bunodactis), with description of Aulactinia incubans n. sp. (Coelenterata: Actiniaria), an internally brooding sea anemone from Puget Sound // Canadian Journal of Zoology. Vol.58. P.2071-2080.

Eash-Loucks W.E., Fautin D.G. 2012. Taxonomy and distribution of sea anemones (Cnidaria: Actiniaria and Corallimorpharia) from deep water of the northeastern Pacific // Zootaxa. Vol.3375. P.1-80.

England K.W. 1991. Nematocysts of sea anemones (Actiniaria, Ceriantharia and Corallimorpharia: Cnidaria): nomenclature // Hydrobiologia. Vol.216/217. P.691-697.

England K.W., Robson E.A. 1984. A new sea anemone from South Africa (Anthozoa, Ptychodactiaria) // The Annals of the South African Museum. Vol.94. No.5. P. 305-329.

Fautin D.G. 2016. Catalog to families, genera, and species of orders Actiniaria and Corallimorpharia (Cnidaria: Anthozoa) // Zootaxa. Vol.4145. No.1. P.1-449.

Galkin S.V., Mordukhovich V.V., Krylova E.M., Denisov V.A., Malyutin A.N., Mikhailik P.E., Polonik N.S., Sanamyan N.P., Shilovb V.A., Ivin V.V., Adrianov A.V. 2019. Comprehensive Research of Ecosystems of Hydrothermal Vents and Cold Seeps in the Bering Sea (Cruise 82 of the R/V Akademik M.A. Lavrentyev) // Oceanology. Vol.59. Issue 4. P.618-621. doi.org/10.1134/S0001437019040052 
Geller J.B., Walton D.E. 2001. Breaking up and getting together: evolution of symbiosis and cloning by fission in sea anemones (Genus Anthopleura) // Evolution. Vol.55. P.1781-1794.

Gusmão L.C., Berniker L., Deusen V. Van, Harris O., Rodríguez E. 2019. Halcampulactidae (Actiniaria, Actinostoloidea), a new family of burrowing sea anemones with external brooding from Antarctica // Polar Biology. Vol.42. No.7. P.1271-1286. https://doi.org/ 10.1007/s00300-019-02516-1

Gusmão L.C., Rodríguez E. 2021. Two sea anemones (Cnidaria: Anthozoa: Actiniaria) from the Southern Ocean with evidence of a deep-sea, polar lineage of burrowing sea anemones // Zoological Journal of the Linnean Society. P.1-24.

Hand C.H. 1954. The sea anemones of central California Part I. The corallimorpharian and athenarian anemones // Wasmann Journal of Biology. Vol.12. P.345375.

Hartog J.C. 1987. A redescription of the sea anemone Bunodosoma biscayensis (Fischer, 1874) (Actiniaria, Actiniidae) // Zoologische Mededelingen, Leiden. Vol.61. P.533-559.

Hertwig R. 1882. Report on the Actiniaria dredged by H.M.S. Challenger during the years 1873-1876 // Report on the Scientific Results of the Voyage of the H.M.S. Challenger during the years 1873-76 (Zoology). Vol.6. P.1-136.

Hertwig R. 1888. Report on the Actiniaria dredged by H.M.S. Challenger during the years 1873-1876 [Supplement] // Report on the Scientific Results of the Voyage of the H.M.S. Challenger during the years 1873-76 (Zoology). Vol.26. P.1-56.

Hoang D.T., Chernomor O., Haeseler A., Minh B.Q., Vinh L.S. 2018. UFBoot2: Improving the ultrafast bootstrap approximation // Molecular Biology and Evolution. Vol.35. P.518-522. https://doi.org/10.1093/ molbev/msx 281

ICZN [International Commission on Zoological Nomenclature]. 1956. Direction 54. Addition to the Official List of Family-Group Names in Zoology, or, as the case may be, to the Official Index of Rejected and Invalid Family-Group Names in Zoology of the family-group names involved in the cases dealt with in Volume 12 of the Opinions and Declarations rendered by the International Commission on Zoological Nomenclature, other than family-group names already dealt with in those Opinions // Opinions and Declarations rendered by the International Commission on Zoological Nomenclature. Vol.12. Pt.26. P.451-470.

Kalyaanamoorthy S., Minh B.Q., Wong T.K.F., Haeseler A., Jermiin L.S. 2017. ModelFinder: Fast Model Selection for Accurate Phylogenetic Estimates // Nature Methods. Vol.14. P.587-589. https://doi.org/10.1038/ nmeth. 4285

Katoh K., Standley D.M. 2013. MAFFT multiple sequence alignment software version 7: improvements in performance and usability // Molecular Biology and Evolution. Vol.30. No.4. P.772-80. https://doi.org/ $10.1093 / \mathrm{molbev} / \mathrm{mst} 010$
Krylova E.M., Galkin S.V., Mordukhovich V.V., Denisov V.A., Malyutin A.N., Mikhailik P.E., Polonik N.S., Sanamyan N.P., Shilov V.A., Adrianov A.V. 2019. [A New Region of Methane Seep Communities of the World Ocean] // Priroda. No.6 (1246). P.24-29 [in Russian].

Kumar S., Stecher G., Tamura K. 2016. MEGA7: Molecular evolutionary genetics analysis version 7.0 for bigger datasets // Molecular Biology and Evolution. Vol.33. P.1870-1874. https://doi.org/10.1093/molbev/msw054

Larsson A. 2014. AliView: a fast and lightweight alignment viewer and editor for large data sets // Bioinformatics. Vol.30. No.22. P.3276-3278.

López-Gónzalez P.J., García-Gómez J.C. 1994. Tres actiniarios nuuvos para la fauna Iberica (Anthozoa, Actiniaria) // Graellsia. Vol.50. P.85-93.

Malakhov V.V. 2004. New Ideas on the Origin of Bilateral Animals // Russian Journal of Marine Biology. Vol.30. Suppl.1. P.22-33.

Malakhov V.V. 2016. Symmetry and the Tentacular Apparatus in Cnidaria // Russian Journal of Marine Biology. Vol.42. No.4. P.287-298.

Manuel R.L. 1981. British Anthozoa keys and notes for the identification of the species. London, New York, Toronto, Sydney, San Fransisco: Academic Press. 241 p.

McMurrich J.P. 1904. The Actiniae of the Plate collection // Zoologische Jahrbücher. Bd.6 (Suppl.). S.215-306.

Molodtsova T.N., Sanamyan N.P., Keller N.B. 2008. Anthozoa from the northern Mid-Atlantic Ridge and Charlie-Gibbs Fracture Zone // Marine Biology Research. Vol.4. P.112-130.

Nguyen L.T., Schmidt H.A., Haeseler A., Minh B.Q. 2015. IQ-TREE: A fast and effective stochastic algorithm for estimating maximum likelihood phylogenies // Molecular Biology and Evolution. Vol.32. P.268274. https://doi.org/10.1093/molbev/msu300

Riemann-Zürneck K. 1978. Tiefsee-Actinien der Familie Actinoscyphiidae aus dem Nordatlantik (Actiniaria, Mesomyaria) // Zoologica Scripta. Bd.7. S.145-153.

Riemann-Zürneck K. 1997. Anthosactis janmayeni Danielssen, 1890, a rare high-arctic sea anemone // Polar Biology. Vol.17. P.487-491.

Riemann-Zürneck K. 1991. A new species of Sicyonis (Actiniaria: Actinostolidae) from the abyssal NE Atlantic // Mitteilungen aus dem Hamburgischen Zoologischen Museum und Institut. Vol.88. P.7-15.

Rodríguez E., Barbeitos M.S., Brugler M.R., Crowley L.M., Grajales A., Gusmão L., Häussermann V., Reft A., Daly M. 2014. Hidden among Sea Anemones: The First Comprehensive Phylogenetic Reconstruction of the Order Actiniaria (Cnidaria, Anthozoa, Hexacorallia) Reveals a Novel Group of Hexacorals // PLoS ONE. Vol.9. No.5. e96998. doi:10.1371/ journal.pone.0096998

Rodríguez E., Daly M. 2010. Phylogenetic Relationships among Deep-Sea and Chemosynthetic Sea Anemones: Actinoscyphiidae and Actinostolidae (Actiniaria: Mesomyaria) // PLoS ONE. Vol.5. No.6. e10958. doi:10.1371/journal.pone.0010958 
Rodríguez E., López-Gónzalez P.J. 2013. New records of Antarctic and Sub-Antarctic sea anemones (Cnidaria, Anthozoa, Actiniaria and Corallimorpharia) from the Weddell Sea, Antarctic Peninsula, and Scotia Arc // Zootaxa. Vol.3624. No.1. P.1-100.

Rodríguez E., Barbeitos M., Daly M., Gusmão L.C., Häussermann V. 2012. Toward a natural classification: phylogeny of acontiate sea anemones (Cnidaria, Anthozoa, Actiniaria) // Cladistics. Vol.28. P.375392.

Ronquist F., Teslenko M., van der Mark P., Ayres D.L., Darling A., Höhna S., Larget B., Liu L., Suchard M.A., Huelsenbeck J.P. 2012. MrBayes 3.2: efficient Bayesian phylogenetic inference and model choice across a large model space // Systematic Biology. Vol.61. P.539-542.

Sanamyan K.E., Sanamyan N.P. 2019. Comments on the nomenclatural status and validity of several familyseries nomina in Actiniaria (Cnidaria, Anthozoa) // Bionomina. Vol.19. P.100-109. https://doi.org/ 10.11646/bionomina.19.1.6

Sanamyan N.P., Sanamyan K.E. 2006. The genera Urticina and Cribrinopsis (Anthozoa: Actiniaria) from the north-western Pacific // Journal of Natural History. Vol.40. No.7-8. P.359-393.

Sanamyan N.P., Sanamyan K.E., 2019. Tetracoelactis ioran, a new genus and species of deep-sea anemones of the family Exocoelactinidae (Cnidaria: Anthozoa: Actiniaria) from the Northwestern Pacific Ocean // Zoosystematica Rossica. Vol.28. No.2. P.238-248. https://doi.org/10.31610/zsr/2019.28.2.238

Sanamyan N.P., Sanamyan K.E., Bocharova E.S. 2015a. Aulactinia vladimiri, a new species of sea anemone (Actiniaria: Actiniidae) from Kamchatka waters, North-West Pacific // Invertebrate Zoology. Vol.12. No.2. P.117-130.

Sanamyan N.P., Sanamyan K.E., Lundsten L. 2015b. Two new deepwater sea anemones (Cnidaria: Anthozoa: Actiniaria) Sicyonis heliodiscus sp.n. (Actinostolidae) and Hormathia pacifica sp.n. (Hormathiidae) from Pacific // Invertebrate Zoology. Vol.12. No.2. P.131-149.

Sanamyan N.P., Sanamyan K.E., McDaniel N. 2013. Two new shallow water sea anemones of the family Actiniidae (Cnidaria: Anthozoa: Actiniaria) from British Columbia (NE Pacific) // Invertebrate Zoology. Vol.9. No.2. P.199-216.

Sanamyan N.P., Sanamyan K.E., McDaniel N., Bocharova E.S. 2018. First record of two genera of sea anem- ones (Cnidaria: Actiniaria), Octineon and Edwardsiella, from the North Pacific Ocean // Invertebrate Zoology. Vol.15. No.1. P. 1-18. doi:10.15298/invertzool.15.1.01

Sanamyan N.P., Sanamyan K.E., McDaniel N., Martynov A.V., Korshunova T.A. Bocharova E.S., 2019. A revision of sea anemones of the genus Cribrinopsis Carlgren, 1921 (Actiniaria: Actiniidae) from British Columbia with the description of a new species // Marine Biodiversity. Vol.49. P.1951-1969. https:// doi.org/10.1007/s12526-019-00956-w

Sanamyan N.P., Sanamyan K.E., Mercier A., Hamel J.F., Bocharova E.S. 2020. Morphological and molecular assessment of large sea anemones (Actiniaria: Actiniidae) in Newfoundland (eastern Canada) // Polar Biology. Vol.43. P.495-509. https://doi.org/10.1007/ s00300-020-02652-z

Sanamyan N.P., Sanamyan K.E., Schories D. 2015c. Shallow water Actiniaria and Corallimorpharia (Cnidaria: Anthozoa) from King George Island, Antarctica // Invertebrate Zoology. Vol.12. No.1. P.1-51.

Sanamyan N.P., Sanamyan K.E., Tabachnik K. 2012. The first species of Actiniaria, Spongiactis japonica gen.n., sp.n. (Cnidaria: Anthozoa) an obligate symbiont of a glass sponge // Invertebrate Zoology. Vol.9. No.2. P.127-141.

Schmidt H. 1974. On evolution in the Anthozoa // Proceedings of the Second International Coral Reef Symposium 1. Great Barrier Reef Committee. Brisbane. P.533-560.

Stephenson T.A. 1918. On certain Actiniaria collected off Ireland by the Irish Fisheries Department, during the years of 1899-1913 // Proceedings of the Royal Irish Academy. Vol.34(B). P.106-164.

Stephenson T.A. 1920. On the classification of Actiniaria 1. Forms with acontia and forms with a mesogloeal sphincter // Quartery Journal Microscopic Sciences. Vol.64. No.4. P.425-574.

Williams R.B. 1996. Measurement of cnidae from sea anemones (Cnidaria: Actiniaria): statistical parameters and taxonomic relevance // Scientia Marina. Vol.60. No.2-3. P.339-351.

Xiao M., Brugler M.R., Broe M.B., Gusmão L.C., Daly M., Rodríguez E. 2019. Mitogenomics suggests a sister relationship of Relicanthus daphneae (Cnidaria: Anthozoa: Hexacorallia: incerti ordinis) with Actiniaria // Scientific Reports. Vol.9. Art.18182 https:// doi.org/10.1038/s41598-019-54637-6

Responsible editor V.N. Ivanenko 